Adalberto José Monteiro Junior

Caracterização limnológica e compartimentação do reservatório de Ponte Nova, Alto Tietê, SP - uma contribuição ao seu manejo

São Paulo 


\section{Caracterização limnológica e compartimentação do reservatório de Ponte Nova, Alto Tietê, SP - uma contribuição ao seu manejo}

Tese apresentada ao Instituto de Biociências da Universidade de São Paulo, para a obtenção de Título de Doutor em Ciências, na Área de Ecologia.

Orientador(a): Dra Gisela Yuka Shimizu

São Paulo 
Ficha Catalográfica

Monteiro Junior, Adalberto José

Caracterização limnológica

e compartimentação do reservatório de Ponte Nova, Alto Tietê, SP - uma contribuição ao seu manejo

Número de páginas 96p

Tese (Doutorado) - Instituto de Biociências da Universidade de São Paulo. Departamento de Ecologia.

1. Limnologia 2. Reservatório 3. Manejo I. Universidade de São Paulo. Instituto de Biociências. Departamento de Ecologia.

Comissão Julgadora:

$\overline{\operatorname{Prof}(a) . \operatorname{Dr}(a) .} \quad \overline{\operatorname{Prof}(a) . \operatorname{Dr}(a) .}$

$\overline{\operatorname{Prof}(a) . \operatorname{Dr}(a) .} \operatorname{Prof}(a) . \overline{\operatorname{Dr}(a) .}$

Prof(a). Dra. Gisela Yuka Shimizu

Orientador(a) 
Dedicatória

Às grandes virtudes.

$E$ àqueles que as possuem.

$E$ àqueles que as praticam 
Epígrafe

“...Nada vos sovino: com a minha incerteza vos ilumino"

Ferreira Gullar 
À minha orientadora, Dra. Gisela Yuka Shimizu, pelo apoio, amizade e principalmente paciência com meus descuidos com prazos.

À Dra Suzana Sendacz, profissional competente, alma generosa, pelo auxílio em diferentes momentos desse trabalho, sem a ajuda da qual ele não teria chegado ao final.

Ao Instituto de Pesca pelo apoio, à Sandra Evangelista e Luiz Evangelista pela realização das análises de água e pela amizade de tanto tempo. À Dra Cacilda Thaís e pelo incentivo, ao Clóvis do Carmo e à Luciana Menezes pela ajuda em algumas análises e ao Professor Marco Antonio, grande auxiliar nos trabalhos de campo. Ao Edison Kubo, amigo de todas as horas e diretor do Instituto de Pesca.

Ao Comitê de Bacia do Alto Tietê e ao FEHIDRO pelo financiamento do projeto do qual esse trabalho fez parte.

À minha família,principalmente meus pais, pela presença constante, apoio e paciência.

Aos colegas Dr. Mário Sérgio Galvão Bueno, Dra Rose Mary Reis Duarte e Dra Maria da Graça Salomão, pelo convívio, pela amizade e pelo incentivo.

Aos amigos de sempre, Gouvêa, Valéria, Vera, Vilma Lea, Irineu, aos mais recentes Bia Vicente, Profa Amélia Vera e à Lia Rachel resgatada do passado pelo apoio e torcida.

À Maria Annunziata Abate e Márcia Cristina, profissionais competentes que me ajudaram a não desistir.

Meu muito obrigado! 
A represa Ponte Nova constitui, juntamente com as represas Jundiaí Taiaçupeba, Paraitinga e Biritiba-Mirim, o Sistema Produtor Alto Tietê, da SABESP, responsável pelo abastecimento de água de parte da Região Metropolitana de São Paulo. O presente trabalho teve por objetivos verificar o comportamento espacial e temporal de variáveis limnológicas do reservatório, identificar o seu grau de trofia e fazer considerações a respeito do seu manejo visando contribuir para a conservação desse ambiente. O trabalho de campo foi realizado ao longo de um período de 12 meses, através de coletas mensais de amostras de água em estações de coletas no reservatório, estabelecidas segundo a sua morfometria e também na entrada de seus principais tributários, Rio Tietê e Rio Claro e a jusante da barragem. Foram determinadas variáveis físicas e químicas da água e também a concentração de pigmentos totais em diferentes profundidades ao longo do perfil vertical das estações do reservatório e na água sub-superficial dos tributários e no Rio Tietê a jusante da represa. Os resultados mostraram características típicas de reservatório oligotrófico, como baixa concentração de pigmentos e de nutrientes e alta transparência. Por outro lado o reservatório apresentou um período de estratificação térmica e química bem definidas, com grande estabilidade, apesar do tempo de residência reduzido, característica essa de ambientes eutrofizados, com alta demanda de consumo de oxigênio nas águas mais profundas. A compartimentação espacial observada, tanto ao longo do eixo longitudinal da represa quanto do eixo transversal no local de maior largura, foi determinada principalmente pela profundidade e pela entrada dos tributários. Os dados de jusante indicam concentrações de nutrientes e de material em suspensão de modo geral inferiores àquelas registradas nos principais tributários, indicando uma retenção eficiente da carga afluente ao reservatório, apesar de não existirem, na bacia, influências antrópicas significativas sobre os corpos d'água. A operação do reservatório influencia de forma significativa seu comportamento limnológico e algumas considerações a esse respeito foram feitas. 
Ponte Nova Reservoir is a component of SABESP's Sistema Produtor Alto Tietê, with Jundiaí Taiaçupeba, Paraitinga e Biritiba-Mirim reservoirs. The system is responsible for the water supply of part of the Região Metropolitana de São Paulo. The aim of the present study was to verify the reservoir spatial and temporal behavior of the limnological variables, to establish its trophic conditions, and to make assessments concerning the management in order to contribute to the conservation of this environment. The field work of this project was undertaken during a period of 12 months, where monthly water samples were collected in stations established in the reservoir according to its morphometry, the entry of the main tributaries, Tietê and Claro rivers, and downstream the dam. Physical and chemical variables of the water and the concentration of total pigments in different depths along the vertical profile of the studied stations were determined, as well as of the water of the subsurface of tributaries and downstream of the dam. The obtained data was characteristic of an oligotrophic reservoir, as low concentrations of pigments and nutrients, and high transparency. In the other hand, the reservoir presented a well defined thermal and chemical stratiphication period, with great stability, in spite of the reduced residence time, characteristic of eutrophic environments, with high oxygen consumption demand in deeper waters. The observed spatial compartimentation, both along the longitudinal axis and the transversal axis at the maximum width, was determined mainly by the depth and by the entry of tributaries. The nutrient and suspended solids concentrations registered downstream were generally inferior to those registered at the main tributaries, indicating an efficient retention of the affluent (ou input) load to the reservoir, in spite of the inexistence of significative anthropogenic influences in the watershed. The reservoir management greatly influences its limnological behavior, and considerations concerning this matter were evaluated. 
Índice

1. Introdução------------------------------------------------------ 1

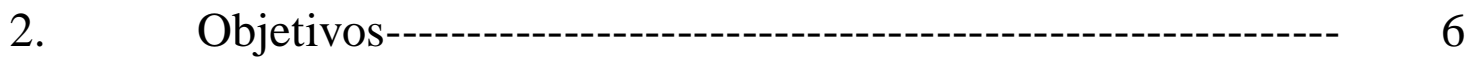

3. Material e Métodos

3.1 Caracterização da Área de Estudo------------------------ 7

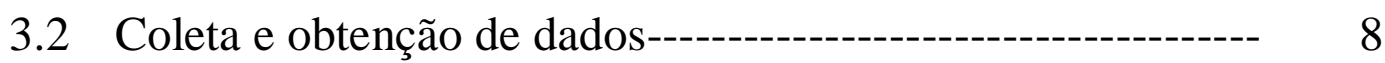

3.3 Organização dos dados----------------------------------- 11

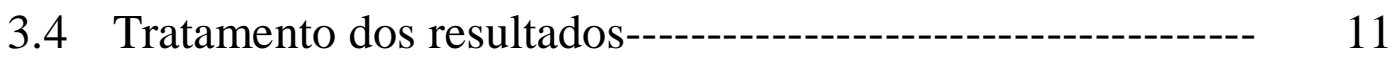

4. Resultados

4.1 Características hidrológicas do reservatório------------------ 14

4.2 Padrões de circulação no reservatório--------------------- 16

4.3 Variação sazonal e compartimentação espacial no reservatório-------------------------------------------------- 42

4.4 Índice de Estado Trófico---------------------------- 60

4.5 Tributários e saída do reservatório---------------------------- 62

5. Discussão--

$6 . \quad$ Conclusões---- 69

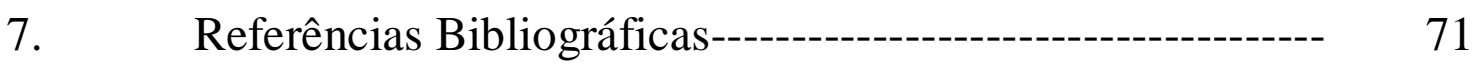


Figura 1 - Localização das estações de coletas de amostras de água

Figura 2: Precipitação mensal na área do reservatório no período de amostragem

Figura 3: Variação das descargas diárias do reservatório no período de amostragem

Figura 4: Volume médio mensal no reservatório no período de amostragem

Figura 5: Tempo de residência da água no reservatório no período de amostragem

Figura 6: Variação mensal da transparência (Secchi) nas estações do reservatório

Figura 7: Relação transparência/profundidade no eixo longitudinal do reservatório

Figura 8: Relação transparência/profundidade no eixo transversal do reservatório

Figura 9: Diagrama profundidade-tempo da temperatura no eixo longitudinal

Figura 10: Diagrama profundidade-tempo da temperatura no eixo tansversal

Figura 11: Resistência Térmica Relativa (RTR) na estação M1

Figura 12: Resistência Térmica Relativa (RTR) na estação M2

Figura 13: Resistência Térmica Relativa (RTR) na estação M3

Figura 14 : Resistência Térmica Relativa (RTR) na estação M4

Figura 15 Profundidade de mistura da coluna d'água

Figura 16: Profundidade de mistura em termos de porcentagem da coluna d'água nos pontos do eixo longitudinal do reservatório 
Figura 17 - Perfis verticais de temperatura no eixo longitudinal do reservatório nos meses em que ocorreu estratificação

Figura 18 Perfis verticais de $\mathrm{pH}$ no eixo longitudinal do reservatório nos meses em que ocorreu estratificação

Figura 19 - Perfis verticais de oxigênio dissolvido no eixo longitudinal do reservatório nos meses em que ocorreu estratificação

Figura 20 - Perfis verticais de potencial de oxi-redução no eixo longitudinal do reservatório nos meses em que ocorreu estratificação

Figura 21: Diagrama profundidade-tempo do $\mathrm{pH}$ no eixo longitudinal do reservatório

Figura 22 Diagrama profundidade-tempo do $\mathrm{pH}$ no eixo transversal do reservatório

Figura 23: Diagrama profundidade-tempo da condutividade elétrica no eixo longitudinal do reservatório

Figura 24: Diagrama profundidade-tempo da condutividade elétrica no eixo transversal do reservatório

Figura 25: Diagrama profundidade-tempo do oxigênio dissolvido no eixo longitudinal do reservatório

Figura 26: Diagrama profundidade-tempo do oxigênio dissolvido no eixo transversal do reservatório

Figura 27: Diagrama profundidade-tempo do potencial de oxi-redução no eixo longitudinal do reservatório

Figura 28: Diagrama profundidade-tempo do potencial de oxi-redução no eixo transversal do reservatório

Figura 29: Diagrama profundidade-tempo de amônia no eixo longitudinal do reservatório

Figura 30: Diagrama profundidade-tempo de amônia no eixo transversal do reservatório 
Figura 31: Diagrama profundidade-tempo do fósforo total no eixo longitudinal do reservatório

Figura 32: Diagrama profundidade-tempo do fósforo total no eixo transversal do reservatório

Figura 33: Média e desvio-padrão dos valores de turbidez, oxigênio dissolvido, potencial de oxi-redução, sólidos totais em suspensão e pigmentos totais nas estações ao longo do eixo longitudinal do reservatório

Figura 34: Média e desvio-padrão dos valores de fósforo total, ferro total, sílica reativa e condutividade elétrica nas estações ao longo do eixo longitudinal do reservatório.

Figura 35: Média e desvio-padrão dos valores de turbidez, oxigênio dissolvido, potencial de oxi-redução, sólidos totais em suspensão e pigmentos totais nas estações ao longo do eixo longitudinal do reservatório

Figura 36: Média e desvio-padrão dos valores de fósforo total, ferro total, sílica reativa e condutividade elétrica nas estações ao longo do eixo transversal do reservatório.

Figura 37: Variação temporal na superfície e fundo de amônia e nitrato nas estações do reservatório

Figura 38 Variação temporal na superfície e fundo de fosfato dissolvido e fósforo total nas estações do reservatório

Figura 39: Variabilidade dos valores relativos de temperatura, $\mathrm{pH}$, condutividade elétrica, oxigênio dissolvido e potencial de oxiredução nos pontos M1 e M2 durante o período de estudo.

Figura 40: Variabilidade dos valores relativos de temperatura, $\mathrm{pH}$, condutividade elétrica, oxigênio dissolvido e potencial de oxiredução nos pontos M3 e M4 durante o período de estudo. 
Figura 41 "Biplot" da ACP com a ordenação nos eixos 1 e 2 dos pontos de amostragem no reservatório em 12 amostragens.

Figura 42 "Biplot" da ACP com a ordenação nos eixos 1 e 2 dos pontos de amostragem no eixo longitudinal do reservatório em 12 amostragens

Figura 43 "Biplot" da ACP com a ordenação nos eixos 1 e 2 dos pontos de amostragem no eixo transversal do reservatório em 12 amostragens

Figura 44 "Biplot" da ACP com a ordenação nos eixos 1 e 2 dos pontos de amostragem do reservatório nas amostragens em que o volume do reservatório era maior que $50 \%$ de sua capacidade

Figura 45: "Biplot" da ACP com a ordenação nos eixos 1 e 2 dos pontos de amostragem do reservatório nas amostragens em que o volume do reservatório era menor que $50 \%$ de sua capacidade

Figura 46: Variação do IET no corpo central do reservatório no período estudado

Figura 47: Variação sazonal de nutrientes nos tributários e na saída do reservatório 
Tabela 1: Síntese da metodologia analítica utilizada

Tabela 2: Classificação de Salas \& Martino (1990) para o IET(PT)

Tabela 3: Valores médios, desvio padrão e coeficiente de variação de variáveis físicas, químicas e biológicas nas estações do reservatório

Tabela 4 : Correlação das variáveis nas estações do reservatório com os componentes principais 1 e 2

Tabela 5 : Correlação das variáveis no eixo longitudinal com os componentes principais 1 e 2 .

Tabela 6: Correlação das variáveis no eixo transversal com os componentes principais 1 e 2 .

Tabela 7: Correlação das variáveis limnológicas com o tempo de residência, volume ocupado do reservatório e precipitação

Tabela 8: Correlação das variáveis no reservatório mais cheio com os componentes principais 1 e 2

Tabela 9: Correlação das variáveis no reservatório mais vazio com os componentes principais 1 e 2

Tabela 10: Índice de Estado Trófico de Carlson modificado por Toledo et al. (1983) calculado para o fósforo total

Tabela 11: Valores médios, desvio padrão e coeficiente de variação de variáveis físicas, químicas e biológicas nos tributários e a jusante do reservatório 


\section{Introdução}

O barramento de rios têm servido há séculos ao homem para $\mathrm{o}$ armazenamento e o controle do fluxo de água, com objetivos variados. A compreensão, contudo, da ecologia desses sistemas teve um desenvolvimento tardio quando comparado com a limnologia de sistemas naturais e só recentemente o acúmulo de conhecimento tem permitido algumas revisões e sínteses (Thornton et al., 1990; Straskraba et al., 1993; Tundisi \& Straskraba, 1999). Tal situação se deve, em parte, a abordagens metodológicas insuficientes do passado, quando represas eram estudadas como se fossem lagos e também pela expressão geográfica pouco significativa que apresentavam, pois dos cerca de $400.000 \mathrm{Km}^{2}$ de águas represadas atuais (Avakyan \& Iakovleva, 1998 in Kennedy, 1999) a maior parte se originou entre 1950 e 1980, quando a limnologia de lagos já tinha atingido uma expressão significativa.

Além de sujeitos à ação de variáveis climatológicas como precipitação, vento e radiação solar, os reservatórios são também influenciados pelos mecanismos operacionais da barragem (condições da saída de água e tempo de residência). A influência dos fatores citados, juntamente com a morfometria do corpo d'água, produz diferenças na circulação vertical e horizontal do sistema ao longo de um gradiente espacial (compartimentação), tornando-os sistemas extremamente dinâmicos, com alta variabilidade temporal e espacial de suas características (Tundisi, 1990; Armengol et al., 1999).

Os reservatórios são sistemas intermediários entre rios e lagos. Intermediários na medida em que o tempo de residência, função de força de grande importância na compreensão da limnologia desses sistemas (Lind, 1984; Straskraba, 1999), apresenta valores intermediários entre um e outro ambiente, mas também porque no seu eixo longitudinal apresenta 
um gradiente que os aproxima dos rios, num extremo e dos lagos no extremo oposto (Thornton et al., 1990).

A identificação dos fatores e mecanismos que determinam a tipologia particular de um lago é crucial para a correta interpretação do estado trófico, determinado não apenas pela concentração de nutrientes mas também pela morfometria, hidrologia e condições climáticas (Salmaso et al., 2003).

Sem contar os aspectos relacionados à produtividade biológica da água e, portanto, do seu efeito retroativo no balanço químico de uma represa, é o tempo de residência da água que controla as concentrações e a capacidade acumulativa de todas as substâncias que entram a partir da bacia de drenagem, seja de forma natural ou artificial (Ambrosetti et al., 2003).

Lewis Jr (2000) aponta para a maior propensão dos lagos tropicais à depleção do oxigênio dissolvido nas águas de fundo e para a necessidade de um controle mais rígido das cargas orgânicas e de nutrientes do que em ambientes temperados, para manter as condições dos sistemas.

A depleção de oxigênio durante a estratificação, que é característica de lagos eutróficos em regiões temperadas ocorre também em reservatórios tropicais de estado trófico reduzido (Townsend, 1996)

$\mathrm{O}$ estabelecimento de gradientes verticais, longitudinais e horizontais em reservatórios está relacionado à hidrologia local e regional, morfologia da bacia e operação do reservatório (Kennedy, 1999). Isso confere a cada reservatório uma expressão única relacionada à sua localização geográfica e às características da barragem e tem resultado em estratégias de manejo individualizadas (Heeftle \& Stevens, 2001).

As represas, por suas características, representam oportunidades de manejo (Kennedy, 1999) que as diferenciam dos lagos, pois além das intervenções possíveis na sua bacia de contribuição e no próprio corpo 
d'água, permitem a manipulação do tempo de residência e, em alguns casos, da altura da saída d'água. Segundo Hueftle \& Stevens (2001), o uso da operação de barragens como variável para manipulação e experimentação com sistemas rios-reservatórios ainda está na sua infância.

Jørgensen (2003) ressalta que a manipulação do tempo de residência, a que o autor se refere como ecohidrologia, pode ser uma ferramenta de manejo extremamente útil.

Um outro aspecto a ser considerado no manejo é a carga interna, principalmente em ambientes onde a ação do vento é suficiente para provocar a ressuspensão do material de fundo, com influência em quase todos os processos nos ecossistemas aquáticos (Hakanson, 2004).

Nas últimas décadas, os aumentos das cargas de nitrogênio e fósforo, de substâncias tóxicas e da produção de toxinas por cianobactérias são alguns dos muitos fatores que atingem os ecossistemas aquáticos continentais (Tundisi, 1999). Segundo este autor, dentre os principais desafios do século XXI, referentes à crise da água e todos os problemas por ela gerados, podem ser destacados a escassez e a disponibilidade de água, a deterioração de sua qualidade, a falta de percepção de gerentes e do público em geral sobre a gravidade da crise e a fragmentação e dispersão do gerenciamento dos recursos hídricos.

Inúmeros fatores interferem na qualidade da água, exigindo estudos detalhados dos processos físicos, químicos e biológicos que ocorrem tanto em sistemas naturais quanto artificiais, destacando-se a importância dos ciclos biogeoquímicos para o entendimento do ecossistema aquático (Carmouze, 1994).

Dentro de uma abordagem ecológica, a tomada de decisão relacionada ao manejo ambiental contempla estudos relativos a estrutura e função dos ecossistemas para o conhecimento do comportamento dos mesmos frente 
a diferentes perturbações. O manejo ambiental consiste, segundo Odum (1985), na habilidade de se monitorar e avaliar os efeitos antropogênicos. A consideração do ecossistema como um complexo multidimensional, sócio-econômico e ecológico (Puccini, 1971) tem reforçado que o manejo do mesmo deve ser, efetivamente, realizado dentro de uma abordagem holística e interdisciplinar da teoria ecológica. Neste contexto, o exercício da interdisciplinaridade tem apresentado numerosas e complicadas dimensões frente a diversidade de profissionais envolvidos na abordagem ambiental.

Tem sido enfatizado pelos especialistas que para todos os corpos de água, em especial para os dos países em desenvolvimento, devem ser projetados modelos de unidade de conservação que procurem conciliar a preservação da biodiversidade e o desenvolvimento social. Esse modelo deve contemplar o uso sustentável dos recursos naturais através do estabelecimento e normatização de atividades econômicas. Essa meta pode ser alcançada através de um gerenciamento dos recursos disponíveis e deve, segundo estes especialistas, ser administrada conjuntamente pelo setor público e a comunidade envolvida.

As opções de manejo em reservatórios podem ser enquadradas em duas estratégias distintas: as ações a nível da bacia hidrográfica ou no próprio reservatório (Straskraba, 1996). No primeiro grupo entram as ações de controle de poluição pontual e as ações sobre o uso do solo, visando diminuir a entrada de nutrientes e sedimentos no reservatório. No segundo grupo, temos a biomanipulação, a aeração da água e do sedimento, a quebra artificial da estratificação, a inativação do fósforo, o controle da altura da saída d'água e a manipulação do tempo de residência. As diferentes estratégias de recuperação e conservação dos ambientes devem considerar as características dos sistemas e os princípios ecológicos fundamentais (Jorgensen, 2006). 
A represa Ponte Nova, constitui, juntamente com as represas Jundiaí e Taiaçupeba, parte do Sistema Produtor Alto Tietê - SPAT. As represas Biritiba e Paraitinga, a primeira em fase final de obras e a segunda em enchimento, também fazem parte do conjunto. O sistema fornece atualmente cerca de $10 \mathrm{~m} 3 / \mathrm{s}$ de água bruta para a ETA - Estação de Tratamento de Águas - da SABESP (Companhia de Saneamento Básico do Estado de São Paulo) em Taiaçupeba.

Este sistema visa a disponibilização de até $15 \mathrm{~m}^{3} / \mathrm{s}$ de água para a Região Metropolitana de São Paulo, RMSP, devendo beneficiar mais de 4,0 milhões de pessoas e garantir o abastecimento da RMSP nos próximos anos, pois os sistemas produtores atuais já são insuficientes para atender a demanda atual, estimada em $70 \mathrm{~m}^{3} / \mathrm{s}$. 


\section{Objetivos}

O estudo teve como objetivos:

a. verificar a existência de compartimentação espacial no reservatório e o comportamento sazonal de variáveis limnológicas

b. avaliar o processo de eutrofização do reservatório através da concentração de nutrientes.

c. estabelecer alternativas de manejo com vistas à preservação da represa. 


\subsection{Caracterização da Área de Estudo}

A represa de Ponte Nova, situada no Rio Tietê, foi concluída em 1972, para fins de abastecimento, controle de enchentes e condições de navegabilidade do rio. Localiza-se entre os municípios de Salesópolis e Biritiba Mirim (23 $33^{\prime} \mathrm{S}$ e $45^{\circ} 50^{\prime} \mathrm{W}$ ), a uma altitude de $765 \mathrm{~m}$, com uma área de drenagem de $320 \mathrm{Km}^{2}$. Sua área de inundação é de 25,7 $\mathrm{Km}^{2}$, a capacidade de armazenamento de 336 milhões de $\mathrm{m}^{3}$ e uma vazão média anual de $3,4 \mathrm{~m}^{3} \mathrm{~s}^{-1}$. O Rio Tietê e o Rio Claro representam seus principais contribuintes.

Segundo a classificação de Koppen o clima predominante é do tipo Cwb, temperado com estação seca no inverno e temperatura média anual de $16^{\circ} \mathrm{C}$ (Nimer, 1989). A precipitação anual média acumulada é de cerca de $1400 \mathrm{~mm}$, com concentração entre os meses de novembro e março.

Localizada no Planalto Atlântico, apresenta formação geológica predominante de rochas granitóides de origem Proterozóica e ocorrência de depósitos de sistemas de leques aluviais da Formação Resende, de origem Cenozóica Terciária, na margem esquerda da represa (Macedo, 1998).

A região localiza-se dentro do Domínio de Mata Atlântica, com apenas $1,3 \%$ de mata natural e um mosaico de diversos estágios sucessionais de Floresta Ombrófila Densa (Mantovani et al., 1990). A região do Alto Tietê-Cabeceiras apresenta um relevo acidentado em que as atividades horti-fruti-granjeiras e reflorestamentos abrangem $60 \%$ da bacia (CETESB, 1995).

Na represa Ponte Nova não ocorreu desmatamento prévio ao enchimento, o que implicou no afogamento da vegetação, o que acarreta liberações 
intensivas de elementos minerais e orgânicos provenientes do processo de decomposição (Garzon, 1984). A decomposição da matéria orgânica no sedimento exerce forte influência no metabolismo do ecossistema aquático.

Apesar do sistema estar situado em áreas protegidas e não receber, portanto, contribuição de fontes poluidoras, sofre influência da vegetação submersa por ocasião do enchimento, apresentando grande quantidade de matéria orgânica no fundo.

Segundo Maier (1985), ocorre estratificação da coluna d'água nos meses de novembro e dezembro, e circulação nos meses de junho e julho.

A Represa de Ponte Nova se caracteriza pelas baixas concentrações de nutrientes e como local de detenção de compostos nitrogenados e fosfatados que provavelmente são retidos ao longo do seu corpo central. Esse papel regulador na descarga de nutrientes é muito importante para todo o sistema do Alto Tietê.

Esta represa estava incluída entre os 17 reservatórios estudados em 1979 pelo Instituto de Pesca no projeto "Tipologia de Reservatórios do Estado de São Paulo" (iniciativa FAPESP), tendo sido determinados fatores abióticos e bióticos (Basile-Martins et al., 1985; Cipoli \& Amorim, 1980; Esteves \& Sendacz, 1988; Maier \& Takino, 1985 a, b; Maier, 1985; Sendacz et al., 1985;Xavier et al., 1985). A represa de Ponte Nova apresentava, na ocasião, níveis tróficos baixos, comparativamente às demais represas estudadas. A eutrofização e aspectos da produção primária nesta represa foram analisados por Jureidini et al. (1983).

\subsection{Coleta e obtenção de dados}

O trabalho de campo do projeto foi realizado ao longo de um período de 12 meses, através de coletas mensais de amostras de água em estações de 
coletas estabelecidas segundo as áreas de maior influência das atividades em torno da represa e também do seu principal tributário. Considerou-se também, na delimitação dos pontos de coleta, as características morfométricas do reservatório.

As estações de coletas na represa estão divididos em dois transectos, um ao longo da represa (eixo maior) com 4 pontos (M1, M2, M3 e M4) e outro no eixo menor perpendicular, no local mais largo do reservatório, onde desemboca o seu maior tributário, o Rio Claro, com 03 pontos (Margem Direita -MD-, braço do Rio Claro- ME, e M2) (figura 1).

As estações ao longo do eixo maior do reservatório estão situadas de maneira equidistante de ambas as margens, a distâncias de cerca de 250 m (M1), 2100m (M2), 5250 m (M3) e 6300 m (M4) do eixo da barragem. Entre as estações M3 e M4, existe a presença de um aterro, construído com a finalidade de promover a travessia do reservatório; desta maneira, verificou-se artificialmente a formação de um compartimento, separando o trecho situado próximo às cabeceiras do rio Tietê do corpo central do reservatório, com papel semelhante a uma barragem.

$\mathrm{O}$ eixo perpendicular é formado pelo ponto M2, pelo ponto MD, a cerca de $500 \mathrm{~m}$ da margem direita e pelo ponto braço do Rio Claro, a cerca de $1000 \mathrm{~m}$ da margem esquerda. 


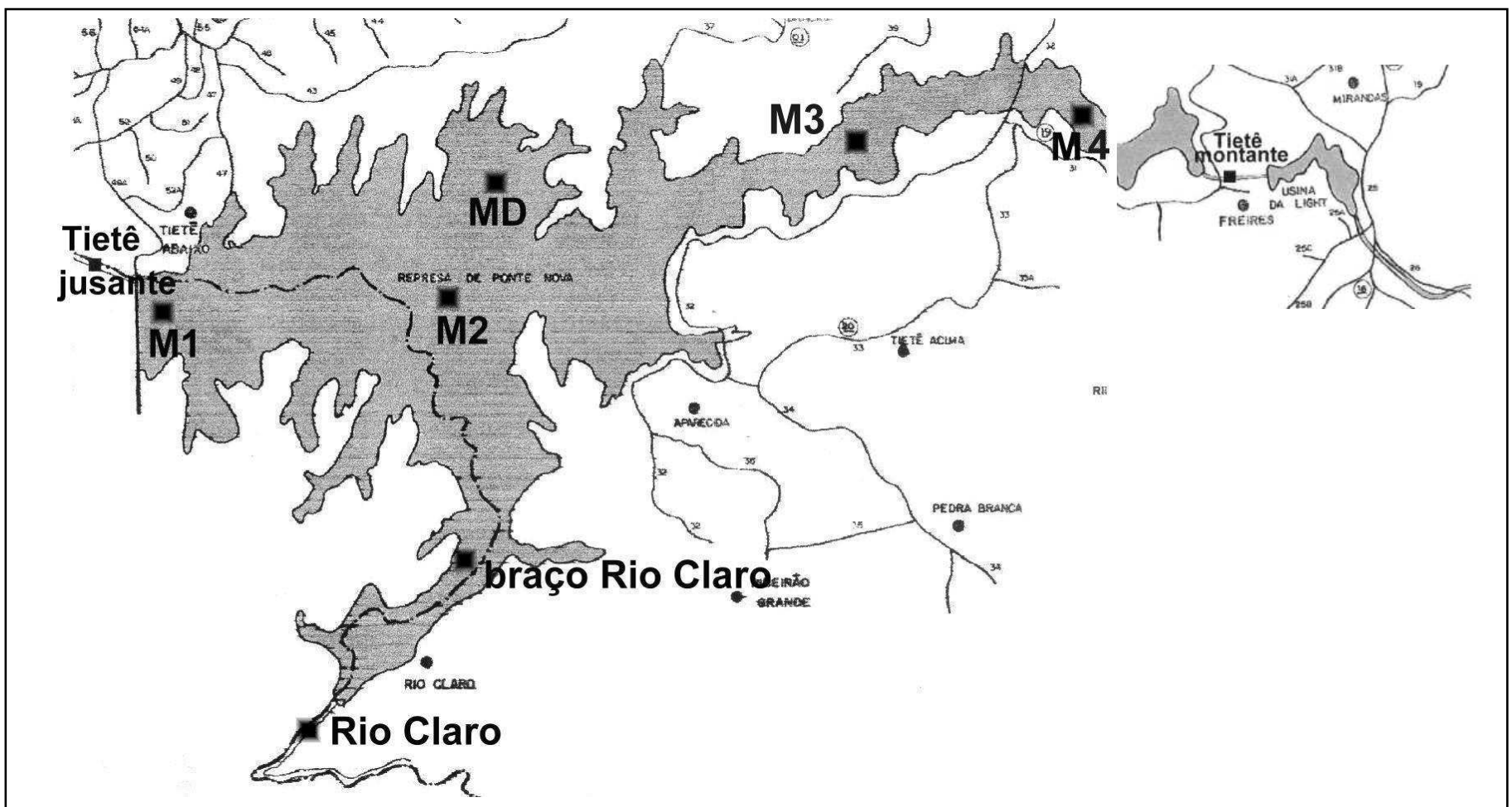

Figura 1 - Localização das estações de coletas de amostras de água

Em cada estação, para estudo da compartimentação vertical da represa, foram coletadas amostras mensais em pelo menos cinco diferentes profundidades, da superfície até o fundo, de acordo com a porcentagem de penetração de luz $(100 \%, 50 \%, 25 \%, 10 \%, 1 \%$, zona afótica e fundo), com exceção dos principais tributários - Tietê montante e Rio Claro e do ponto a jusante - Tietê jusante, que foram amostrados apenas na superfície.

As seguintes variáveis físicas e químicas foram determinadas, utilizandose métodos do Standard Methods (APHA, 1998):

Tabela 1: Síntese da metodologia analítica utilizada

\begin{tabular}{lll} 
Temperatura da água & Medida direta & Horiba U-10 \\
\hline PH & Medida direta & Horiba U-10 \\
\hline Condutividade elétrica & Medida direta & Horiba U-10 \\
\hline
\end{tabular}




\begin{tabular}{|c|c|c|}
\hline Turbidez & Medida direta & Horiba U-10 \\
\hline Oxigênio dissolvido & Medida direta & Horiba U-10 \\
\hline Alcalinidade total & Acidimétrico & com indicador metil orange \\
\hline DBO & Medida direta & oxímetro DIGIMED DMO-2 \\
\hline Sólidos totais em suspensão & Gravimetria & balança analítica Mettler AE 240 \\
\hline Cor & Colorimetria & colorímetro HACH \\
\hline Ferro total & Colorimetria & método da orto-fenantrolina \\
\hline Oxigênio consumido & Titulometria & método do permanganato de potássio \\
\hline Cloreto & Titulometria & com $\mathrm{Ag}+$, indicador cromato de potássio \\
\hline Dureza total & Titulometria & com EDTA e indicador negro de eriocromo $\mathrm{T}$ \\
\hline Dureza do cálcio & Titulometria & com EDTA e indicador murexida \\
\hline Sódio & Fotometria de chama & fotômetro CELM FC-280 \\
\hline Potássio & Fotometria de chama & fotômetro CELM FC-280 \\
\hline Amônia & Colorimetria & reativo de Nessler \\
\hline Nitrito & Colorimetria & método do n-naftil \\
\hline Nitrato & Colorimetria & redução com cádmio \\
\hline Fósforo inorgânico dissolvido & Colorimetria & método do ácido ascórbico \\
\hline Sílica "reativa" & Colorimetria & método do molibdato de amônio \\
\hline Fósforo total & Colorimetria & digestão com persulfato de potássio \\
\hline Nitrogênio total & Colorimetria & digestão com persulfato de potássio \\
\hline Clorofila a e feofitina & Colorimetria & extração com etanol \\
\hline
\end{tabular}

\subsection{Organização dos dados:}

Os dados obtidos, seja aqueles obtidos em campo, como os que resultaram de procedimentos de laboratório, foram organizados em um banco de dados, utilizando para isso o programa Microsoft Access. Dessa forma ficou facilitada a recuperação dos dados da forma desejada para a confecção de tabelas e gráficos, assim como para a análise por testes estatísticos.

\subsection{Tratamento dos resultados:}


Os resultados obtidos foram analisados em termos de sua magnitude e variação espacial e sazonal, procurando-se esboçar um quadro de funcionamento do sistema e das principais funções de força atuantes sobre ele, além de compará-los aos obtidos em sistemas similares existentes na literatura.

Foram calculados os valores médios, os desvios-padrão e os coeficientes de variação (CV) das variáveis analisadas por estação de coleta e por ocasião de amostragem. Para evidenciar a variação sazonal de algumas variáveis nas estações do corpo central do reservatório foram calculados seus valores relativos, ou seja, a diferença entre o valor médio na coluna d'água e a média anual dividida pela média anual, conforme proposto por Håkanson \& Peters (1995). A variação ao longo do tempo foi mostrada também por diagramas profundidade-tempo construídos com a utilização do programa Surfer 8.0. A compartimentação espacial do reservatório foi analisada através de técnicas da estatística multivariada (Ter Braak, 1987; Legendre \& Legendre, 1983) utilizando a análise dos componentes principais com o programa PC-ORD 4.0.

A Resistência Térmica Relativa (RTR adimensional) foi calculada de acordo com Schäfer (1985), com base na diferença entre a densidade de 2 profundidades $\left(\mathrm{d}_{2}-\mathrm{d}_{1}\right)$, distantes de $0,5 \mathrm{~m}$, dividida pela diferença de densidade da água à temperatura de $5^{\circ} \mathrm{C}$ e $4^{\circ} \mathrm{C}\left(8 \times 10^{-6}\right)$. Foram utilizados os dados de densidade da água constantes em Hutchinson (1957).

$$
\mathrm{RTR}=\left(\mathrm{d}_{2}-\mathrm{d}_{1}\right) / 8 \times 10^{-6}
$$

A zona de mistura, considerada aquela de mistura turbulenta, foi calculada aquela que se estende da superfície até aquela em que o gradiente de densidade ultrapassou 0,02Kg.m ${ }^{-4}$ (Reynolds, 1984).

Foi calculado também o índice de estado trófico de Carlson modificado por Toledo et al. (1983), ajustado para ambientes tropicais. O Índice foi 
calculado a partir das concentrações de fósforo total na água, utilizando a fórmula:

$$
\operatorname{IET}(\mathrm{PT})=10\left(6-\frac{\ln (80,32 / \mathrm{PT})}{\ln 2}\right)
$$

Para a classificação do estado trófico dos pontos de amostragem nas ocasiões das coletas foram utilizados os limites estabelecidos por Salas \& Martino (1990).

Tabela 2: Classificação de Salas \& Martino (1990) para o IET(PT)

\begin{tabular}{ll}
\hline Ultra - oligotrófico & $<20$ \\
\hline Oligotrófico & $21-40$ \\
\hline Mesotrófico & $41-50$ \\
\hline Eutrófico & $51-60$ \\
\hline Hipereutrófico & $>61$ \\
\hline
\end{tabular}




\section{1 Características hidrológicas do reservatório}

Na Figura 2 são apresentados os valores de precipitação acumulada mensal do reservatório no período de estudo, evidenciando uma estação chuvosa de outubro a março e uma estação seca de abril a setembro. No período de nov/2000 a out/2001 a precipitação total acumulada foi de $1390 \mathrm{~mm}$.

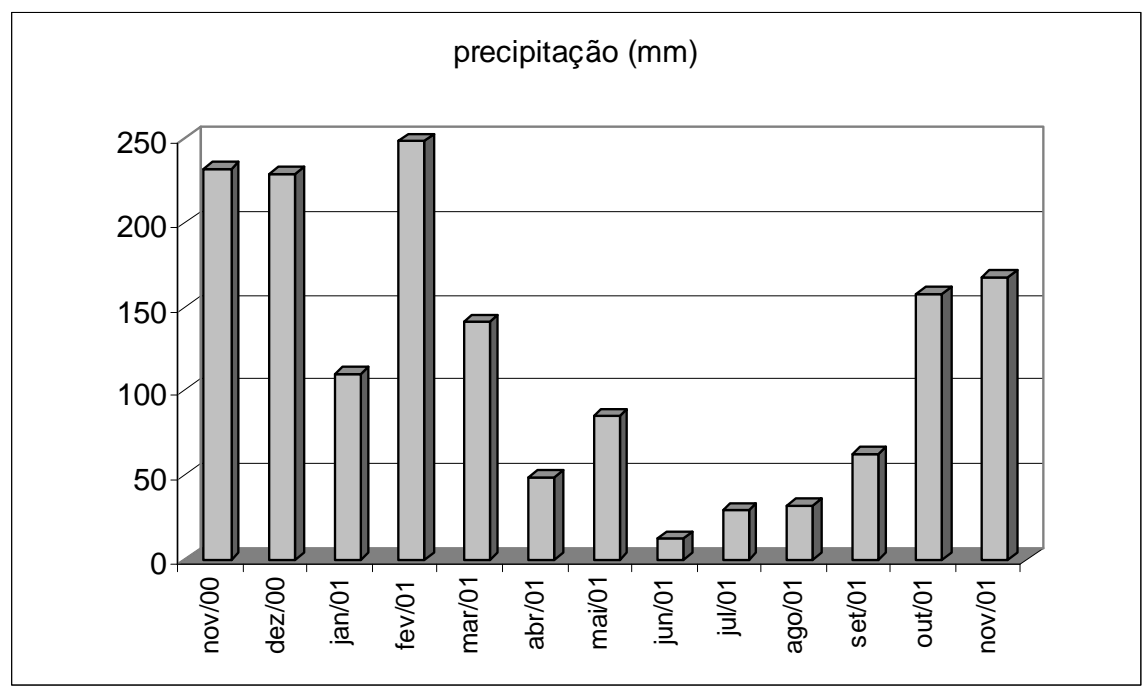

Fonte: DAEE

Figura 2: Precipitação mensal na área do reservatório no período de amostragem

A operação do reservatório de Ponte Nova é condicionada às necessidades de oferta de água do Sistema Produtor Alto Tietê (SPAT) operado pela SABESP. A água lançada por Ponte Nova no Rio Tietê é, em parte, captada pela Estação Elevatória de Biritiba e daí transferida, por um sistema de canais e túneis, para o Reservatório de Jundiaí e posteriormente para o de Taiaçupeba, onde é feita a captação pela SABESP (Sendacz et al., 2005). Ponte Nova opera, portanto, acumulando água no período de chuvas e liberando água no período de estiagem. As vazões lançadas a jusante no período de estudo estão na Figura 3 e a Figura 4 mostra a variação do volume do reservatório. 


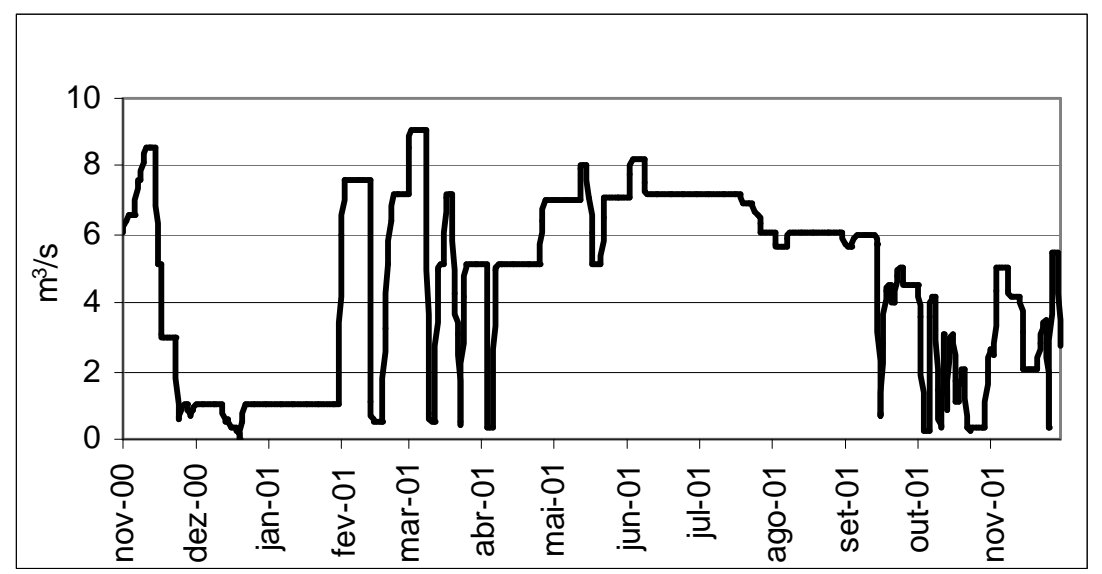

Fonte: DAEE

Figura 3: Variação das descargas diárias do reservatório no período de amostragem

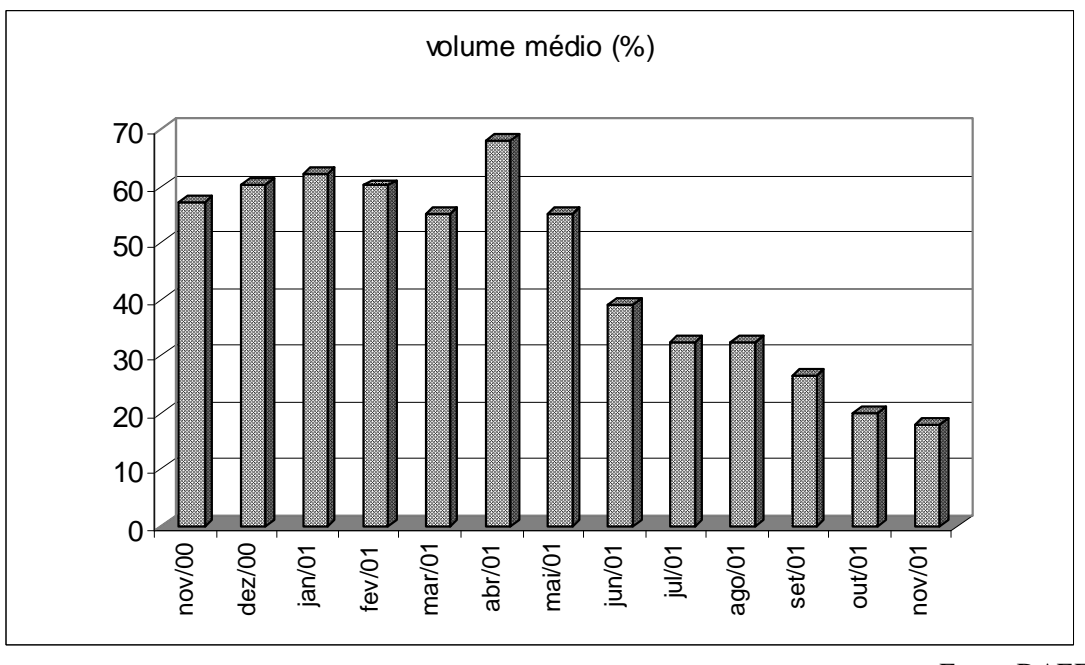

Figura 4: Volume médio mensal no reservatório no período de amostragem

As vazões de saída variaram entre 0 e $9,06 \mathrm{~m}^{3} \cdot \mathrm{s}^{-1}$ e o volume médio entre $68 \%$ em abri/2001 e 18\% em novembro/2001, o que implicou no deplecionamento acentuado do reservatório, com exposição de grandes áreas marginais e redução da profundidade dos locais de coleta.

Na Figura 5 são mostrados os tempos de residência da água a cada mês, no período de estudo, com variação entre 5 e 79 dias. Os valores mais elevados corresponderam aos períodos de maior precipitação em função do regime de operação do reservatório atuar no sentido de acumular água nesse período. 


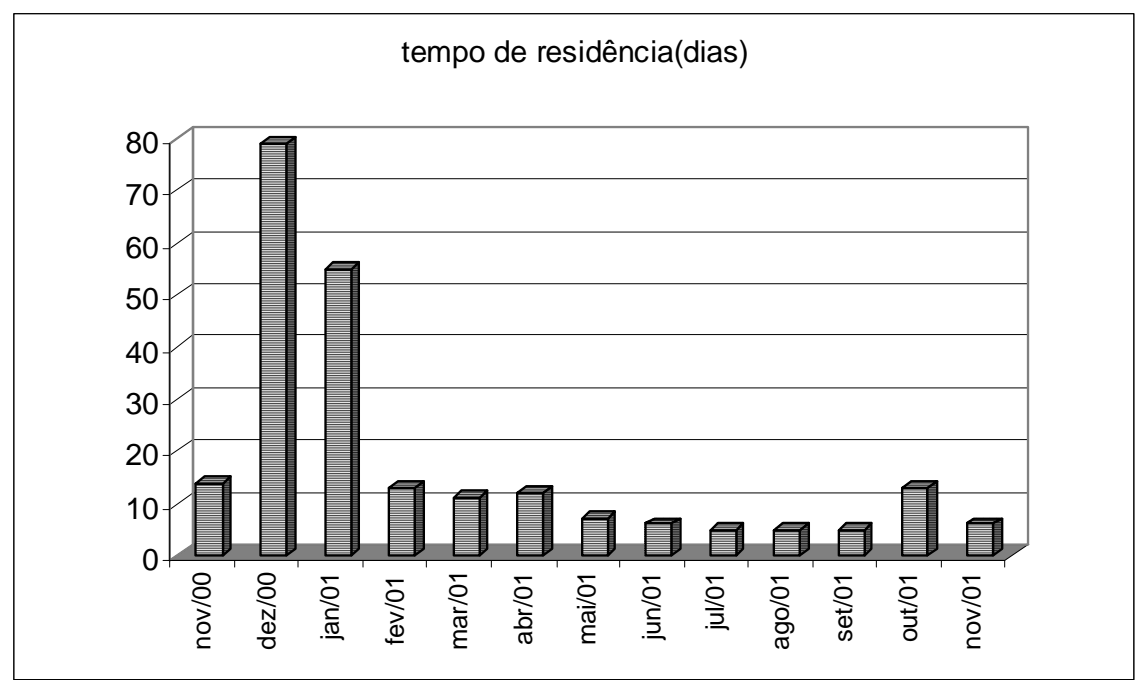

Figura 5: Tempo de residência da água no reservatório no período de amostragem

\section{2. Padrões de circulação no reservatório}

Na Figura 6 são mostradas as variações da transparência nos pontos do reservatório no período de estudo.

Os valores variaram entre $1,70 \mathrm{~m}$ e 3,70 $\mathrm{m}$ em M1, entre 2,0 e 3,60 m em M2, entre 0,50 e 2,10m em M3 e entre 0,60 e 1,50m em M4 numa clara tendência de diminuição da zona eufótica ao longo do eixo longitudinal do reservatório, ou seja, da barragem até a entrada do rio Tietê. No eixo transversal estudado, correspondendo à região de maior largura do reservatório, as medidas foram um pouco inferiores (entre 1,70 e 3,20m em MD e entre 0,90 e 3,00m no braço do Rio Claro) ao corpo central (M2). 

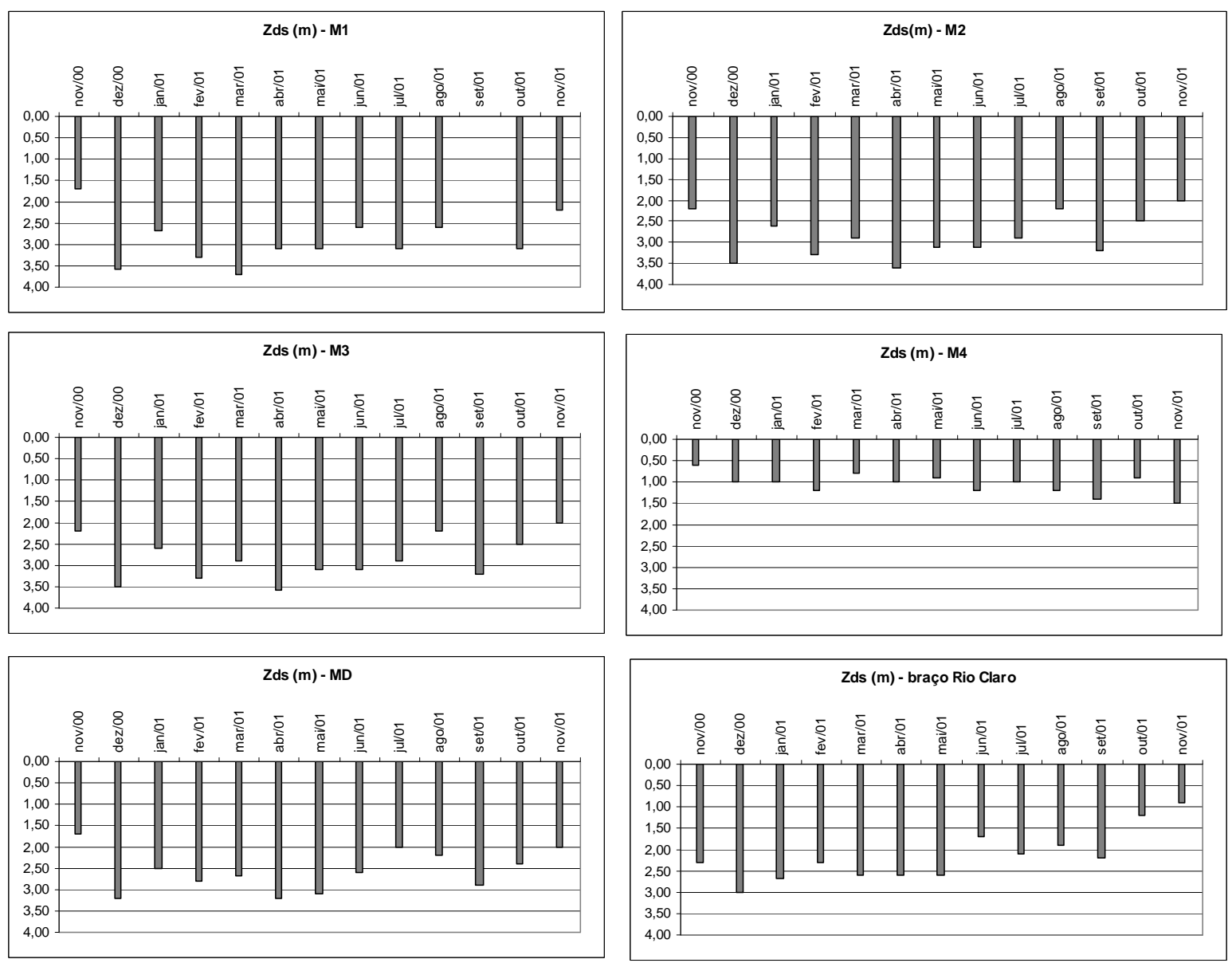

Figura 6: Variação mensal da transparência (Secchi) nas estações do reservatório

A relação profundidade do disco de Secchi/profundidade do ponto (Zds/Zmax) mostrou valores mais elevados nos locais menos profundos e uma tendência de elevação com o deplecionamento da represa (Figuras 7 e 8 .

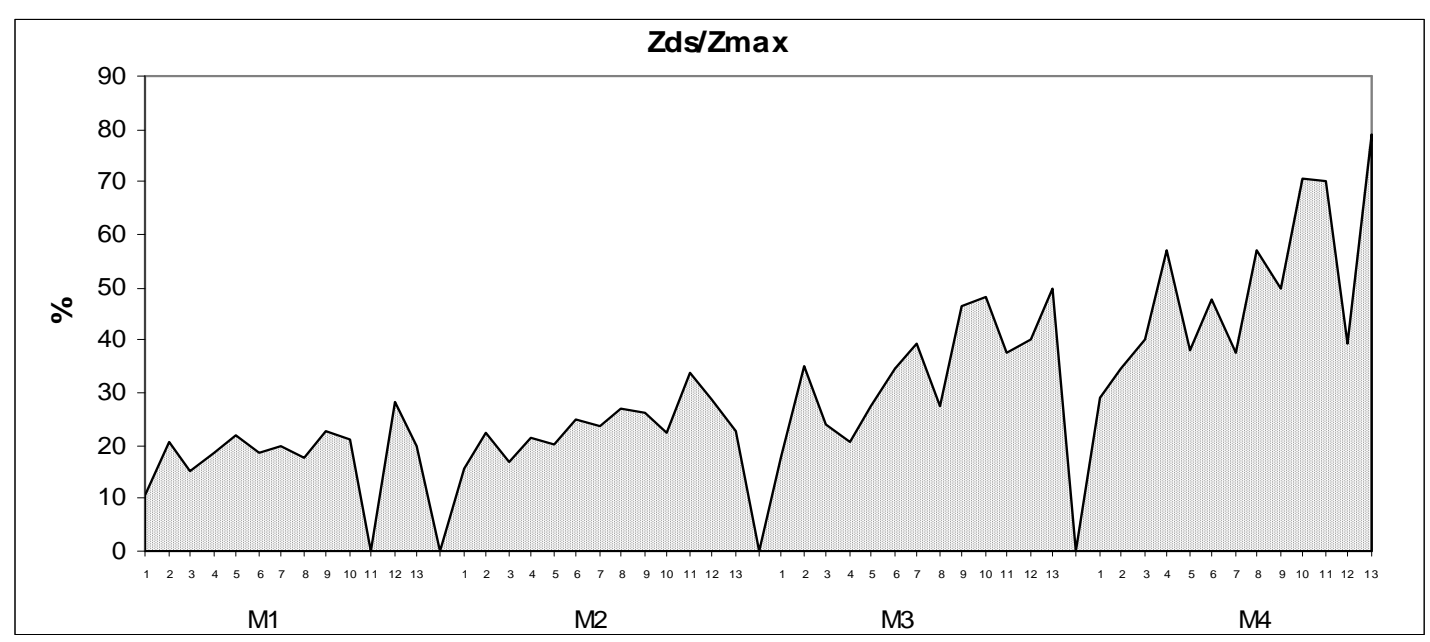

Figura 7: Relação transparência/profundidade no eixo longitudinal do reservatório 


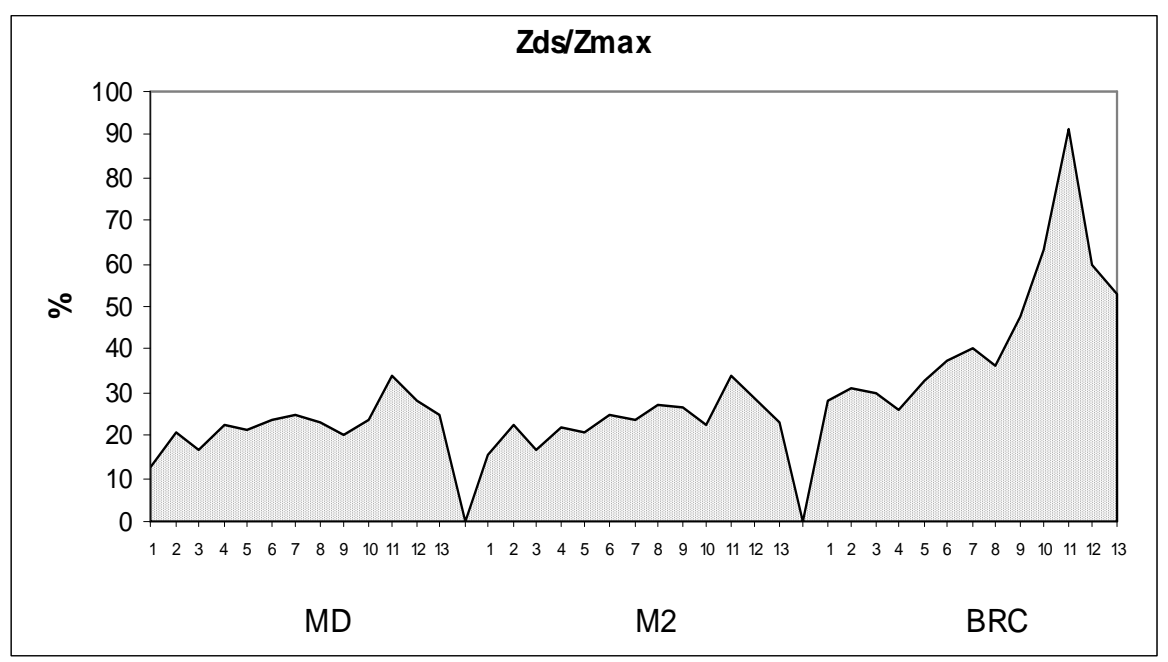

Figura 8: Relação transparência/profundidade no eixo transversal do reservatório

O perfil térmico nas estações de coleta é mostrado nos diagramas profundidade-tempo das figuras 9 e 10.

Nota-se a presença de estratificação térmica bem marcada entre novembro de 2000 a março de 2001. A partir de abril o sistema passou a ter circulação completa, voltando a estratificar em novembro/2001. A estratificação térmica se mostrou mais marcada nas estações de maior profundidade, M1, M2 e MD. Nos locais de menor profundidade, M3 e braço do Rio Claro (BRC), as diferenças de temperatura entre superfície e fundo foram menores. No BRC, além da ação do vento, a entrada do Rio Claro, o segundo maior tributário da represa, representou um fator de instabilidade na estrutura vertical do sistema.

Esse comportamento quanto a períodos de estratificação e circulação, embora tenha existido, não foi tão marcado em M4, uma vez que nesse local a represa se acha parcialmente isolada pela existência de um aterro, o que provocou uma variação menor do nível d'água quando comparada ao restante da represa. Isso conferiu a esse compartimento uma tendência de estratificação no fundo nos períodos em que havia circulação nos outros pontos da represa, apesar da baixa profundidade da coluna d'água. 

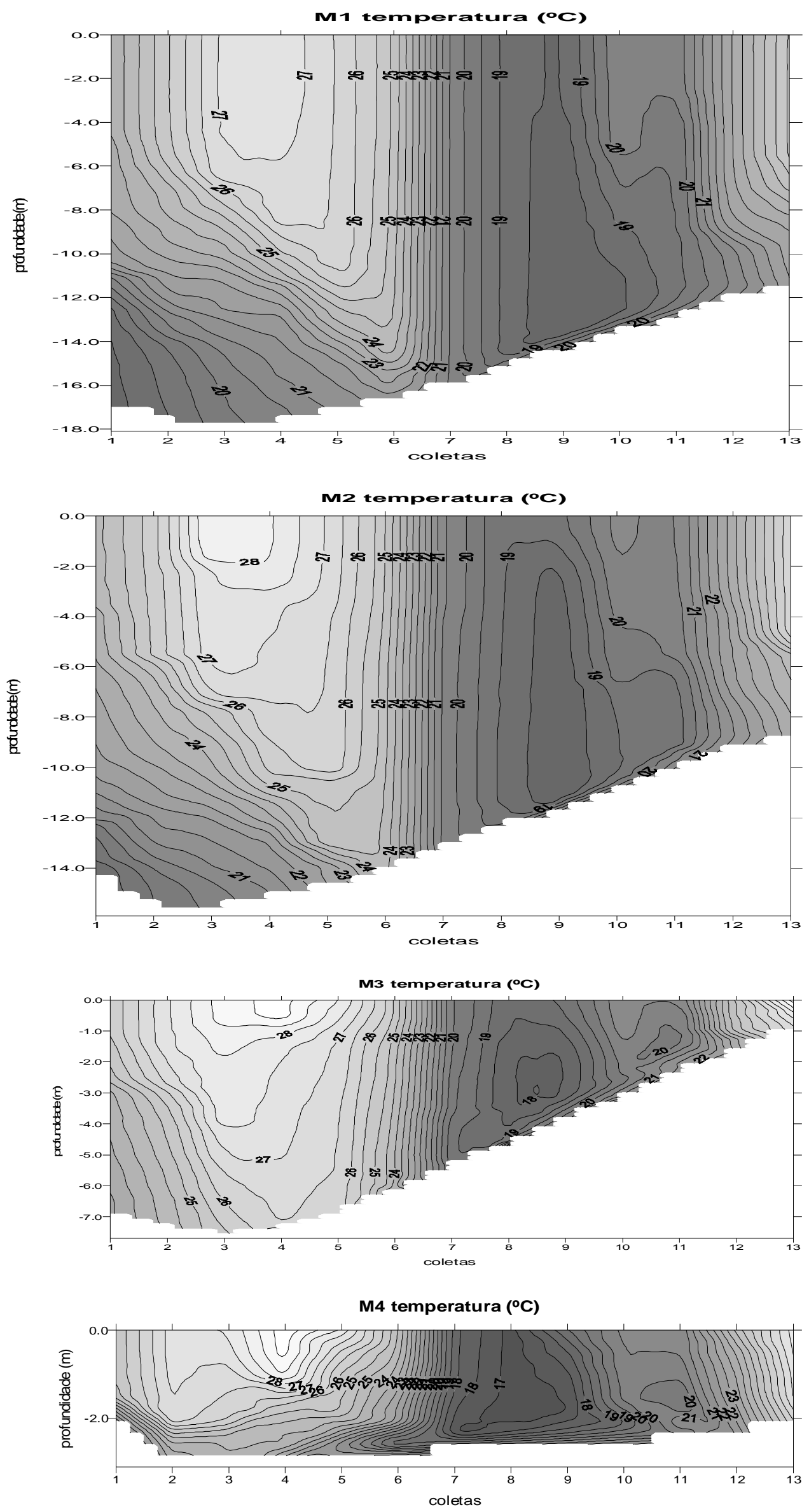

Figura 9: Diagrama profundidade-tempo da temperatura no eixo longitudinal 

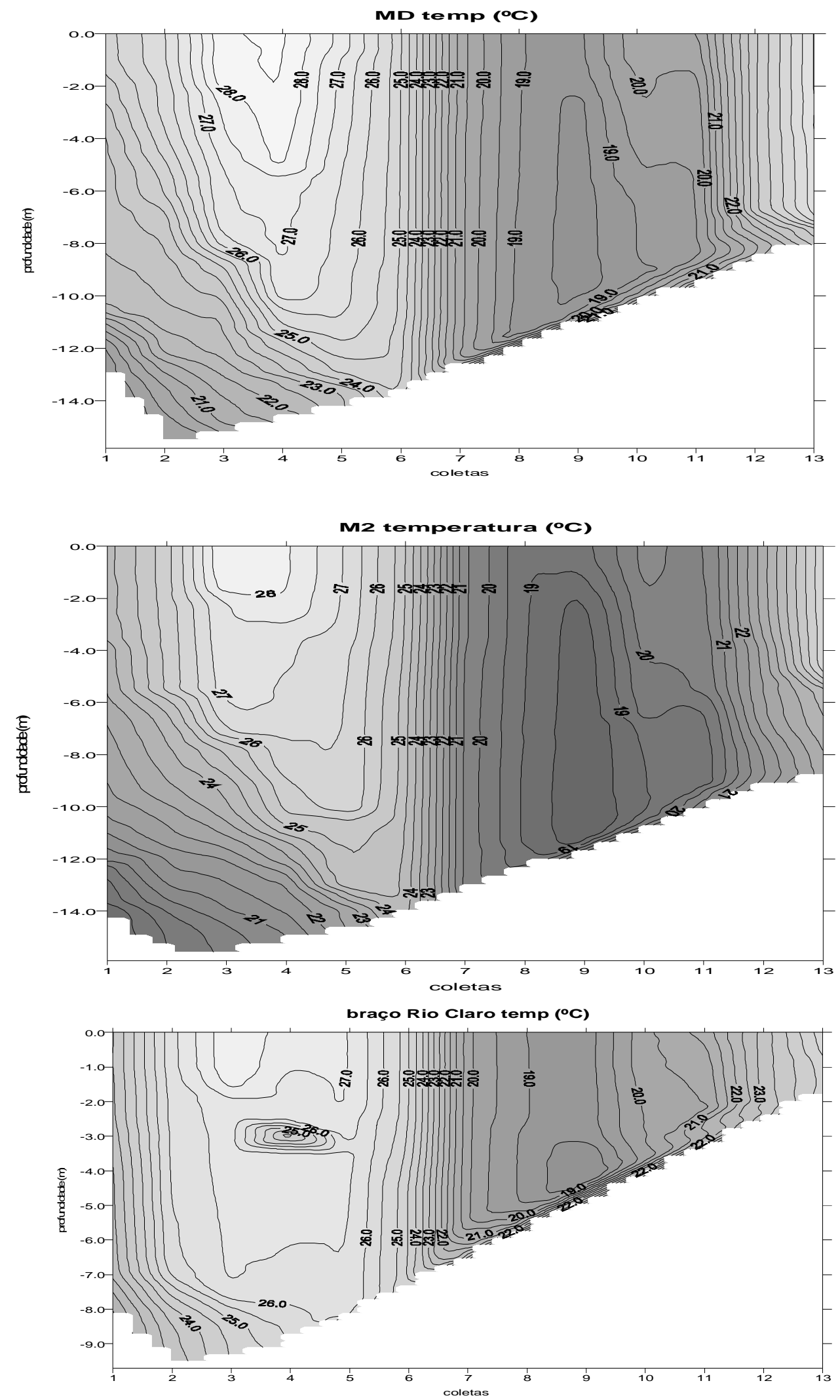

Figura 10: Diagrama profundidade-tempo da temperatura no eixo tansversal 
A Resistência Térmica Relativa nos pontos M1, M2, M3 e M4 é apresentada nas Figuras 11, 12, 13 e 14. Os dados indicam a grande resistência à mistura das camadas de água do epilímnio e hipolímnio no período de novembro a março. Entre abril e outubro, a instabilidade do sistema é evidente, permitindo a circulação verificada nos dados de temperatura.

Na Figura 15 observa-se a profundidade de mistura da coluna d'água calculada a partir dos dados de temperatura e densidade da água. $\mathrm{Na}$ Figura 16 a profundidade de mistura em cada estação do eixo longitudinal do reservatório é apresentada em termos de porcentagem da coluna d'água. Os dados indicam maior tendência à estratificação no período chuvoso e de circulação completa no período seco. Quando se observa circulação a partir da superfície, se estendendo a uma pequena profundidade, trata-se, provavelmente, de uma estratificação superficial de caráter diário. Nesses casos, quando ocorridos no período chuvoso, gradientes mais significativos de densidade são observados em profundidades maiores. Nos ocorridos no período seco, normalmente foram observadas condições homogêneas abaixo dessa camada superficial. 
NOV/00

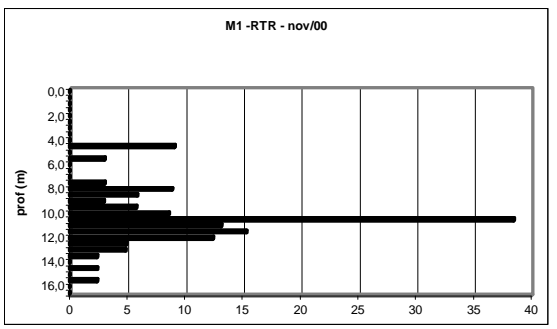

DEZ/2000

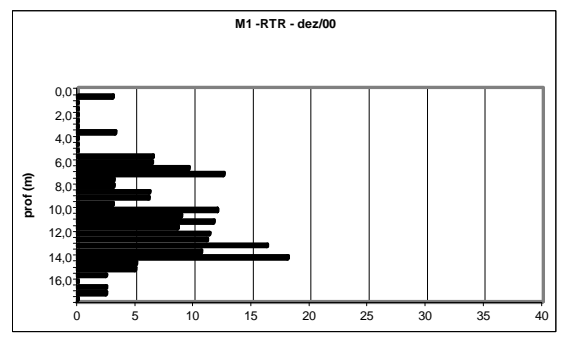

JAN/2000

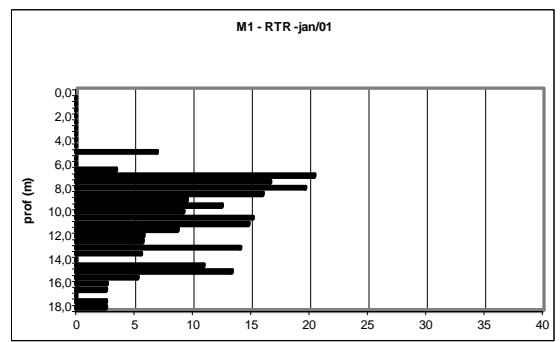

FEV/2000

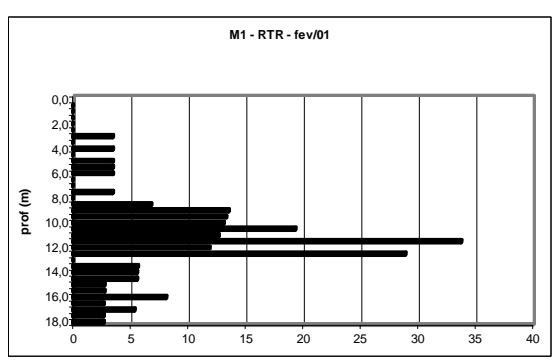

$\mathrm{MAR} / 2000$

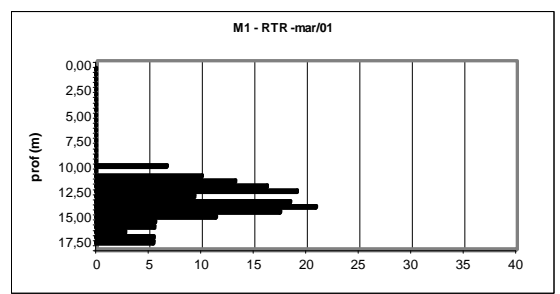

$\mathrm{ABR} / 200$

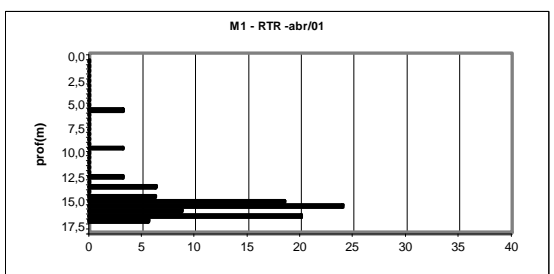

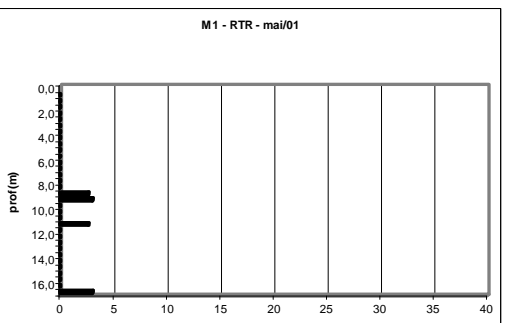

MAI/2000

JUN/2000
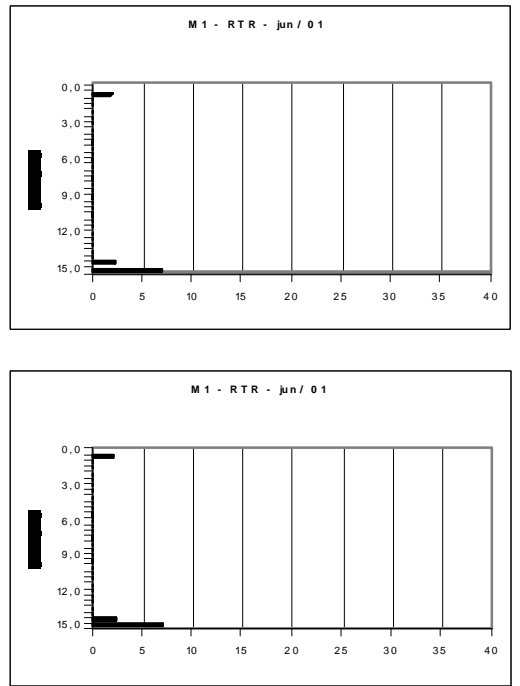

$\mathrm{JUL} / 2000$
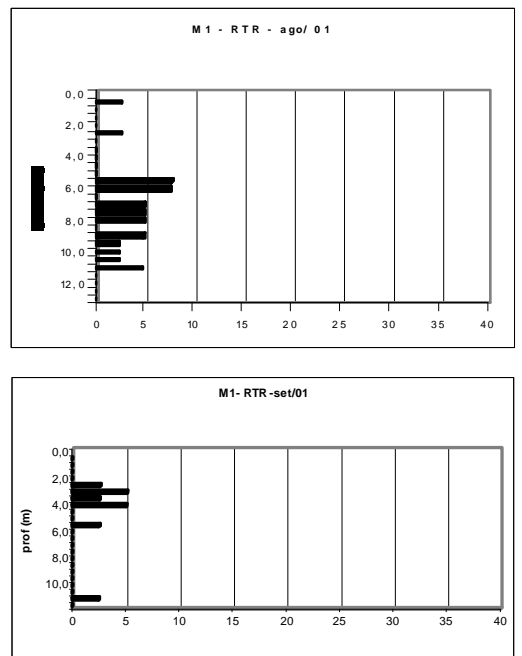

SET/2000

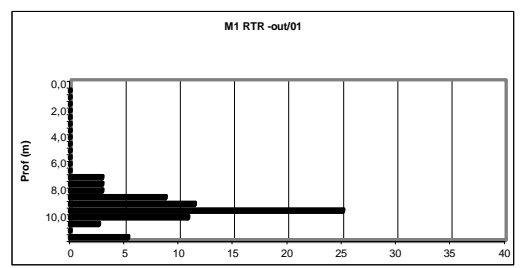

$\mathrm{AGO} / 2000$

OUT/2000

Figura 11: Resistência Térmica Relativa (RTR) na estação M1 


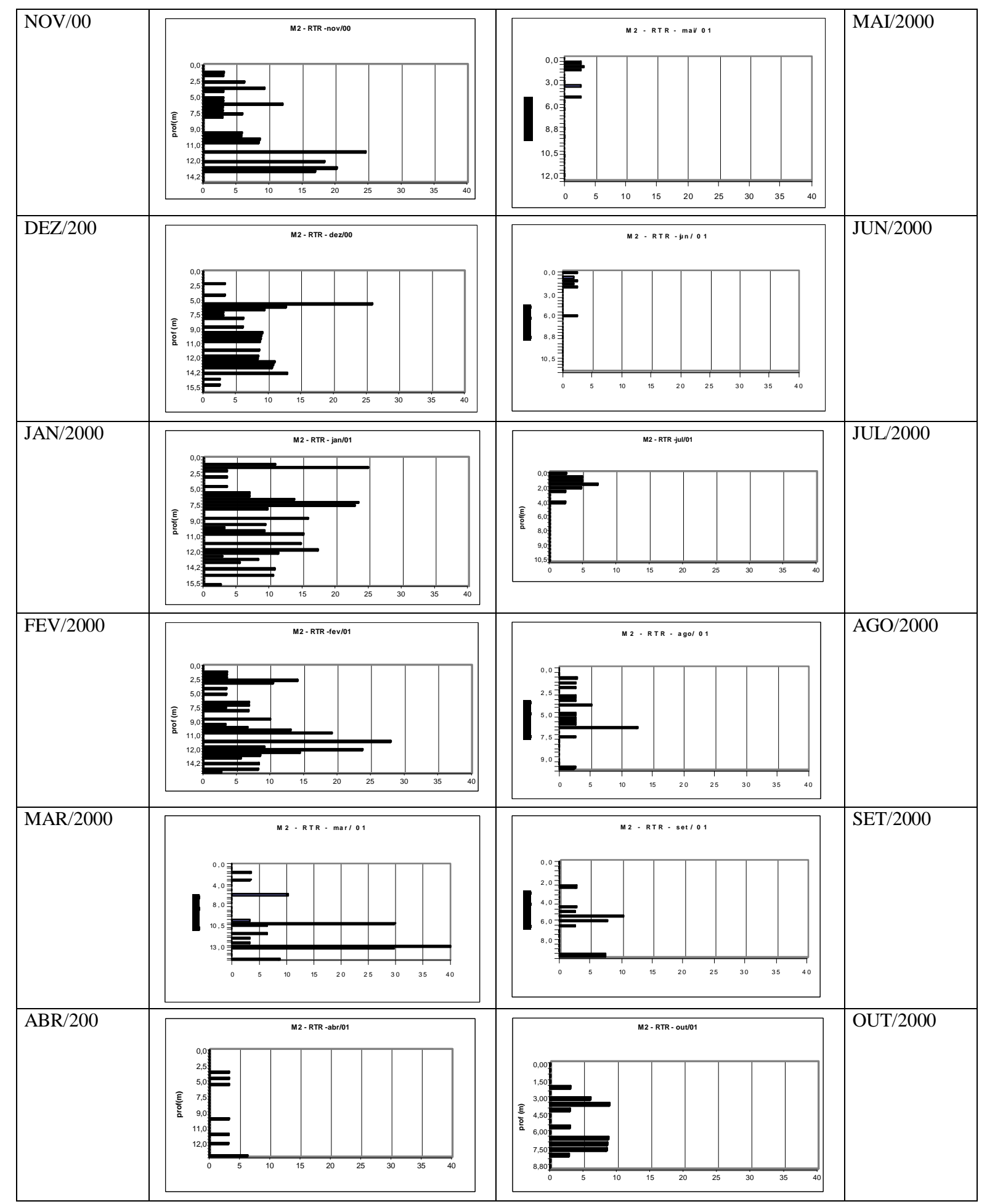

Figura 12: Resistência Térmica Relativa (RTR) na estação M2 


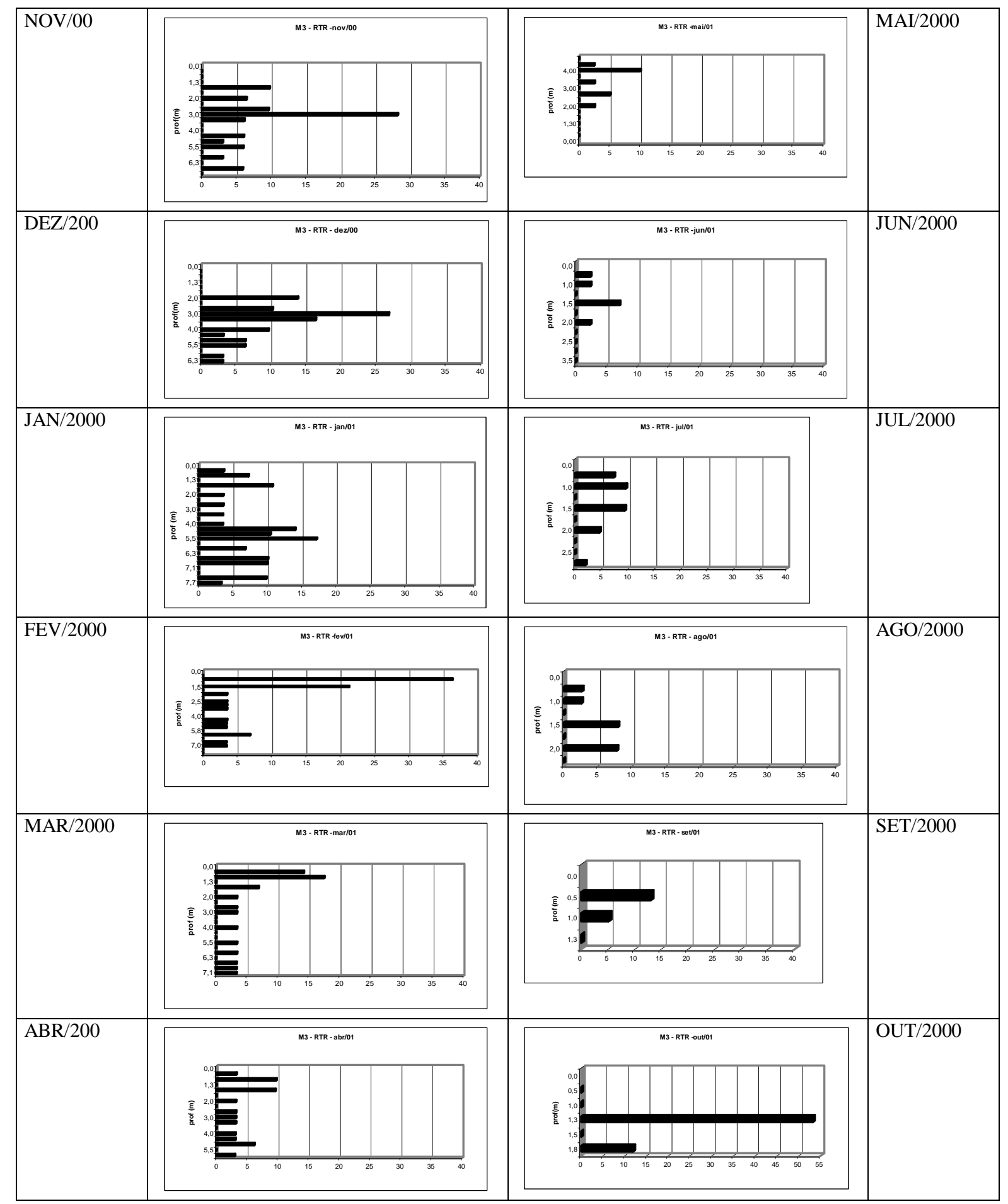

Figura 13: Resistência Térmica Relativa (RTR) na estação M3 


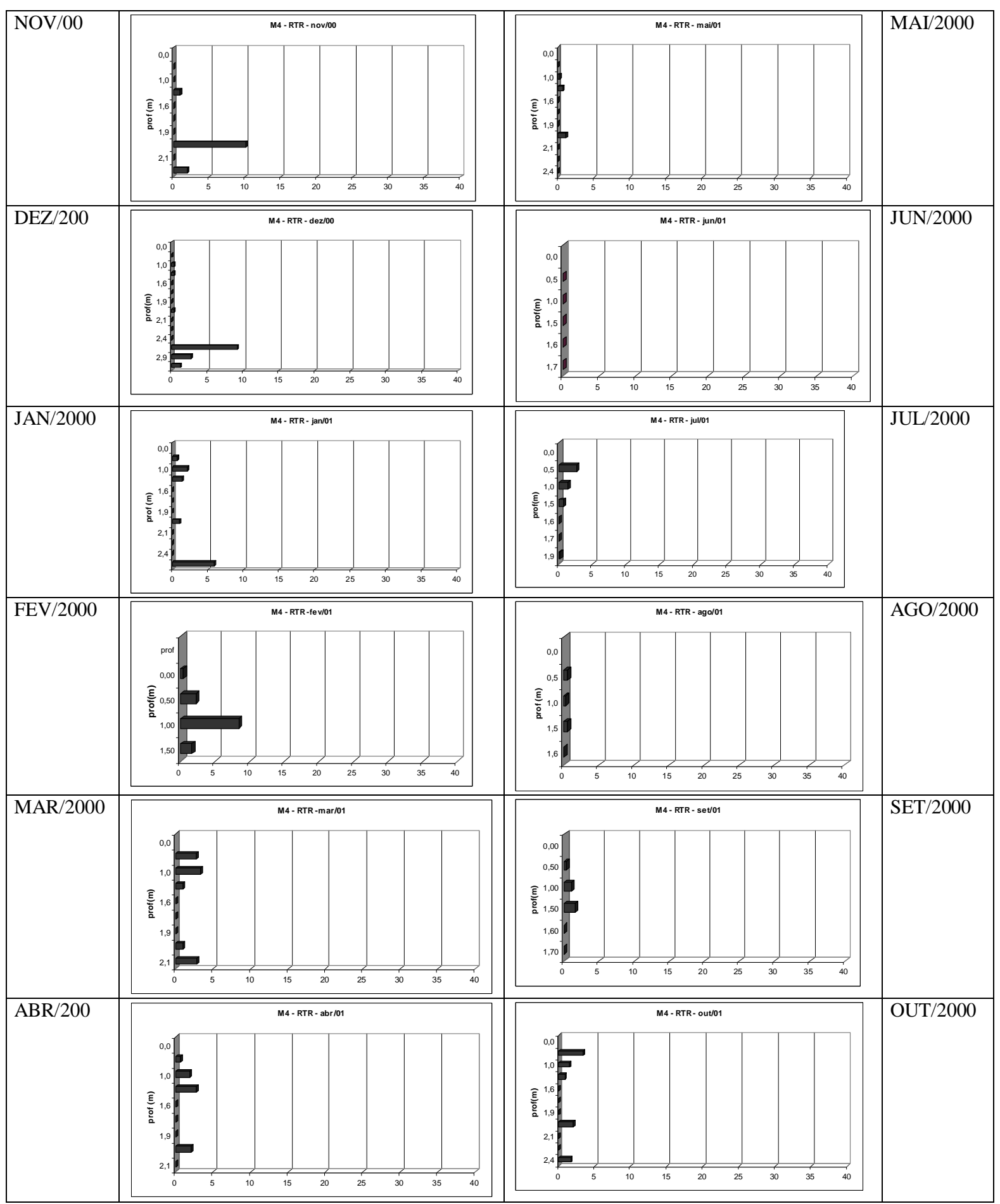

Figura 14 : Resistência Térmica Relativa (RTR) na estação M4 


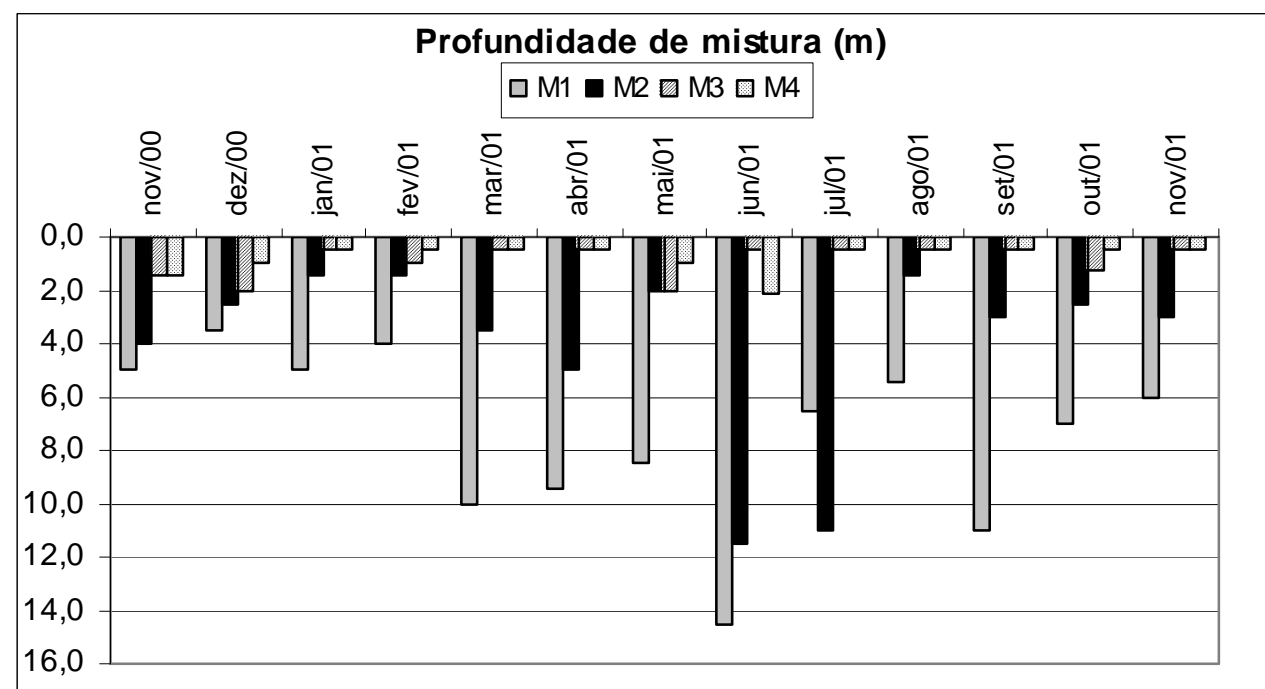

Figura 15 Profundidade de mistura da coluna d'água

Profundidade de mistura (\% da coluna dágua) - M1

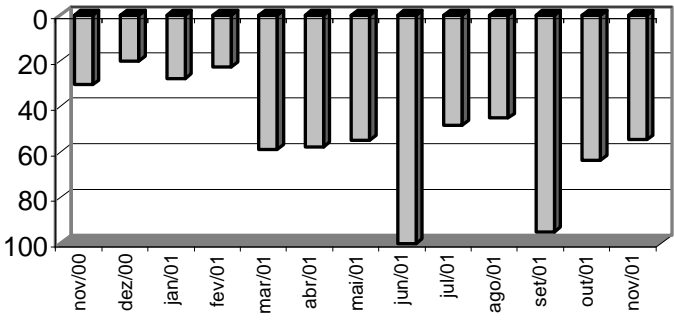

Profundidade de mistura (\% da coluna d'água) - M3

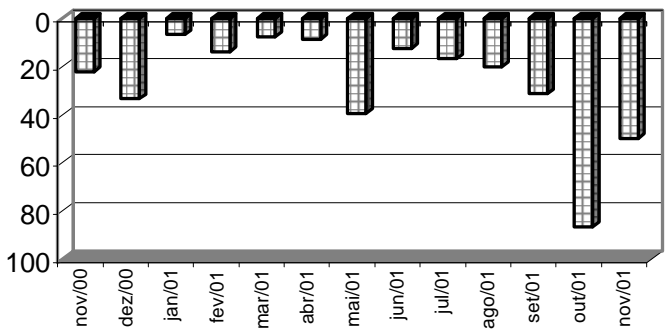

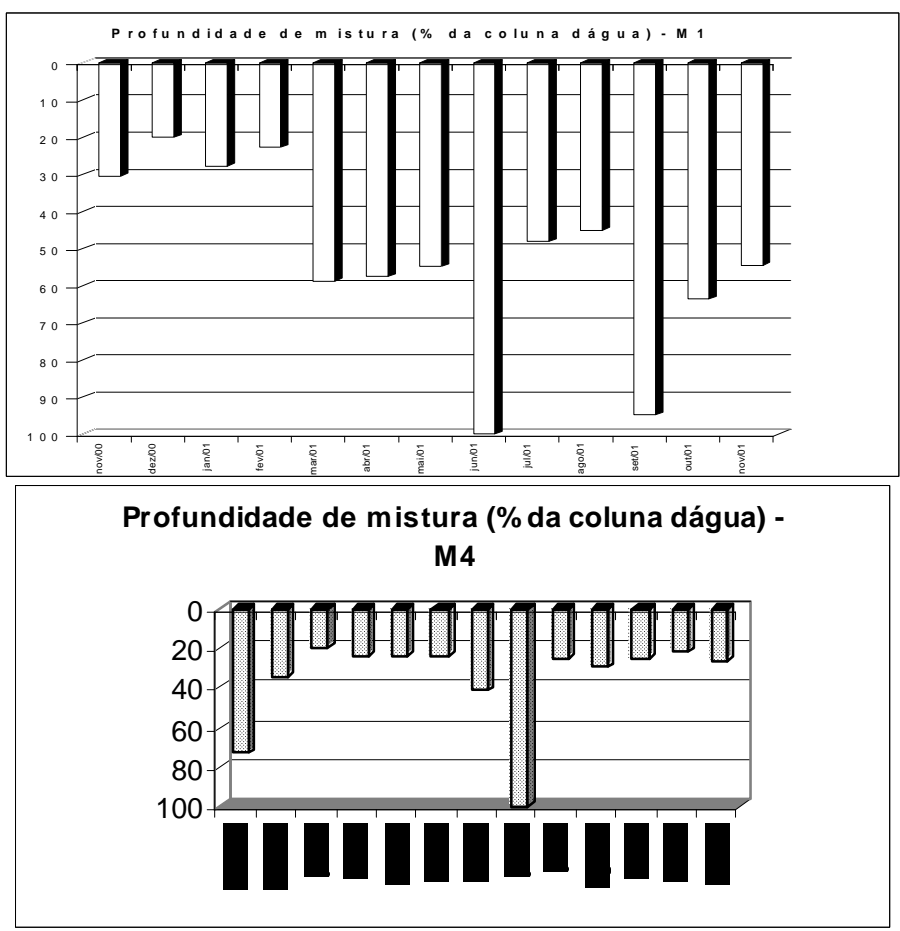

Figura 16: Profundidade de mistura em termos de porcentagem da coluna d'água nos pontos do eixo longitudinal do reservatório

Nas Figuras 17 a 20 são mostrados os perfis verticais de temperatura, $\mathrm{pH}$, oxigênio dissolvido e potencial de oxi-redução nos pontos do eixo longitudinal do reservatório nos meses de novembro de 2000 a abril de 2001, mostrando a estratificação térmica e química do sistema, com forte condição redutora no fundo. 


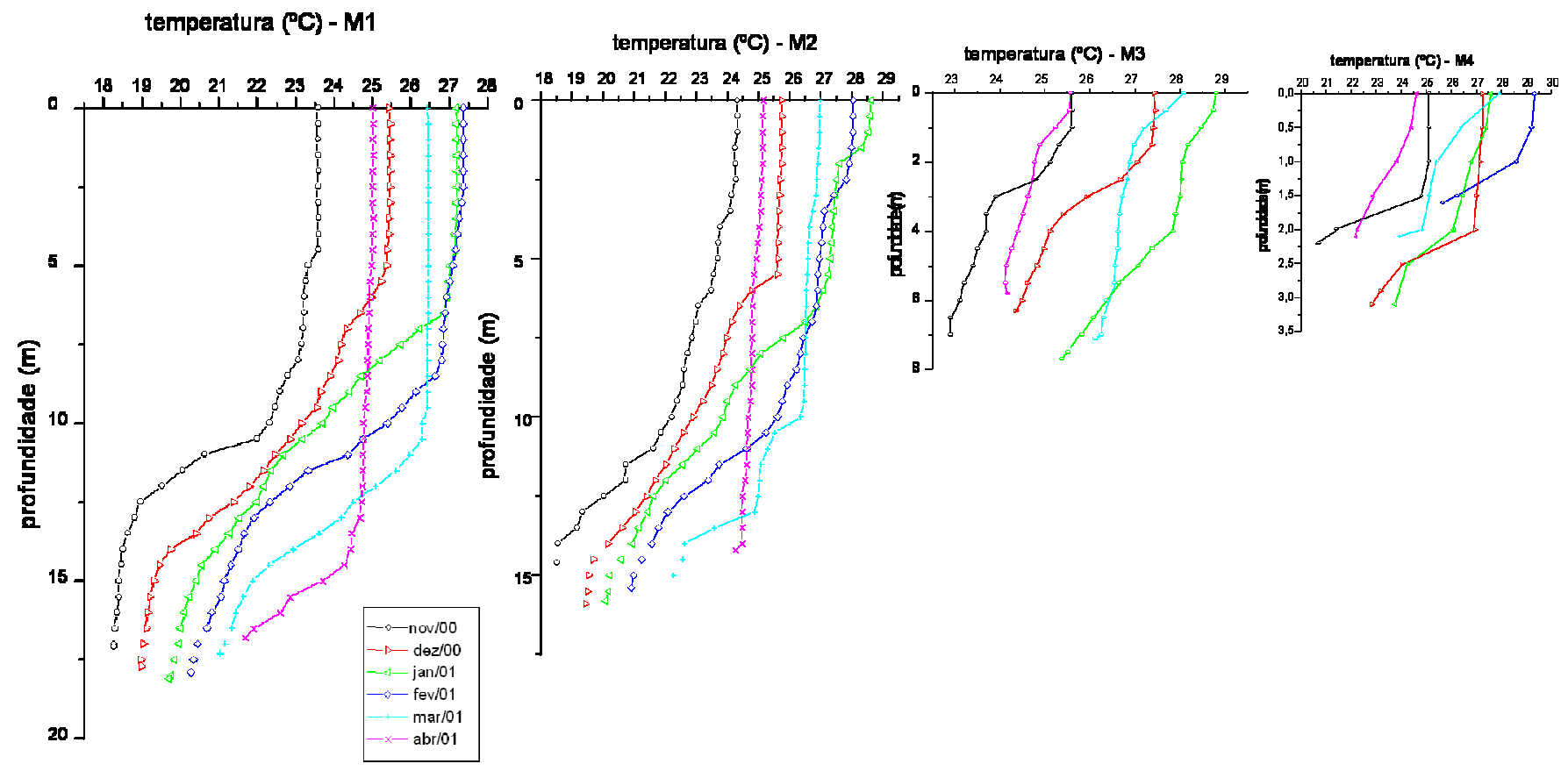

Figura 17 - Perfis verticais de temperatura no eixo longitudinal do reservatório nos meses em que ocorreu estratificação

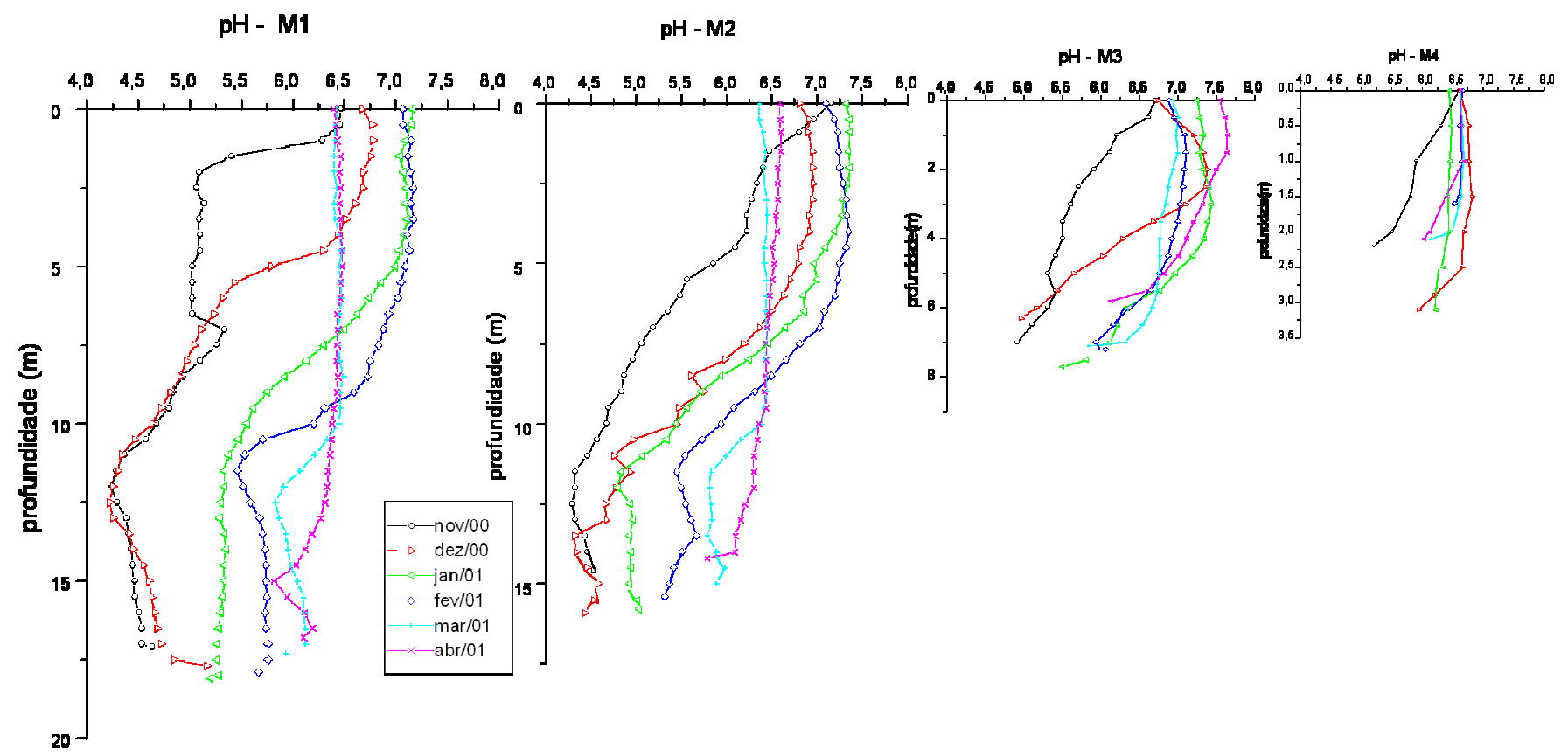

Figura 18 Perfis verticais de $\mathrm{pH}$ no eixo longitudinal do reservatório nos meses em que ocorreu estratificação 


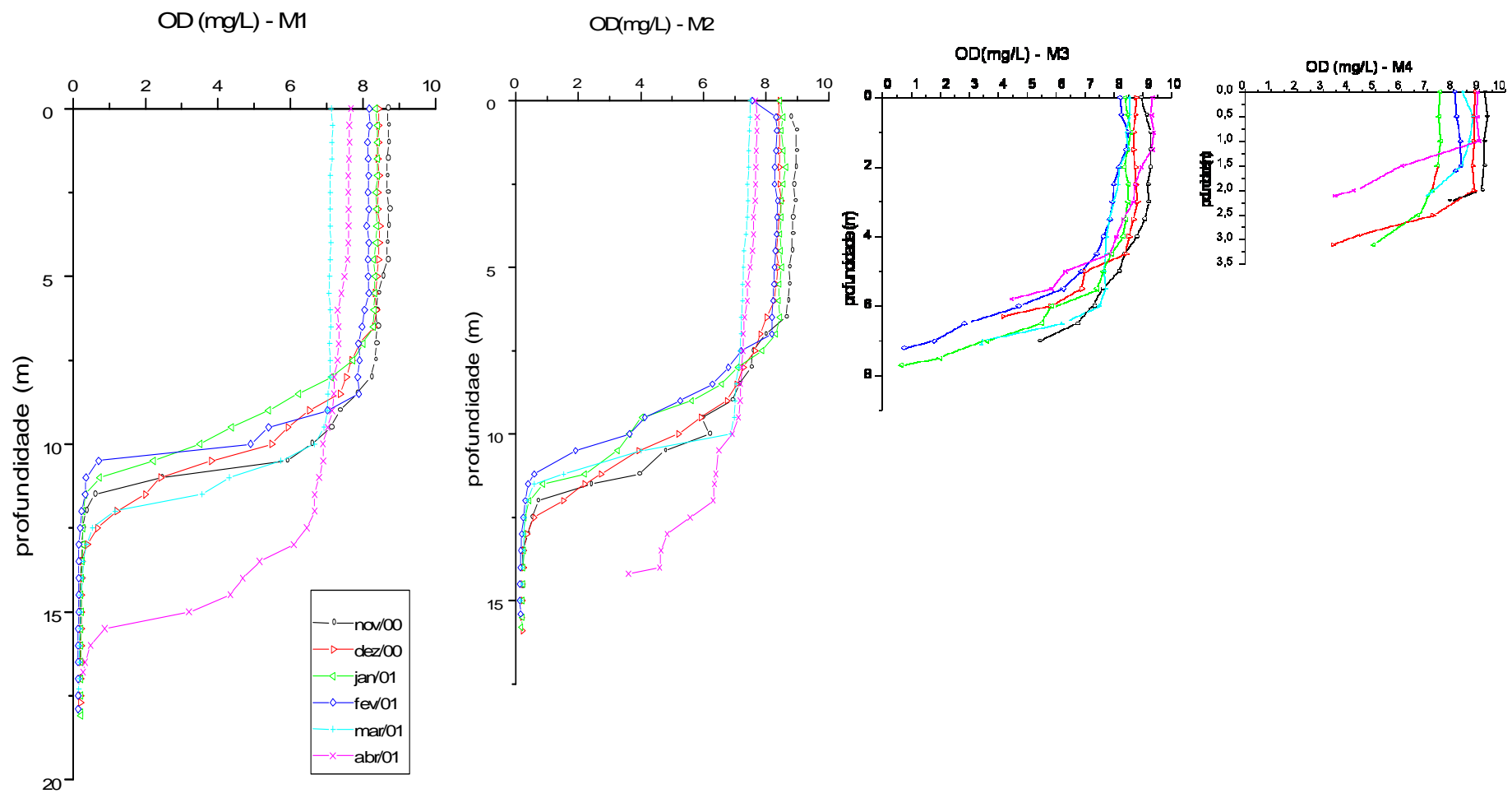

Figura 19 - Perfis verticais de oxigênio dissolvido no eixo longitudinal do reservatório nos meses em que ocorreu estratificação

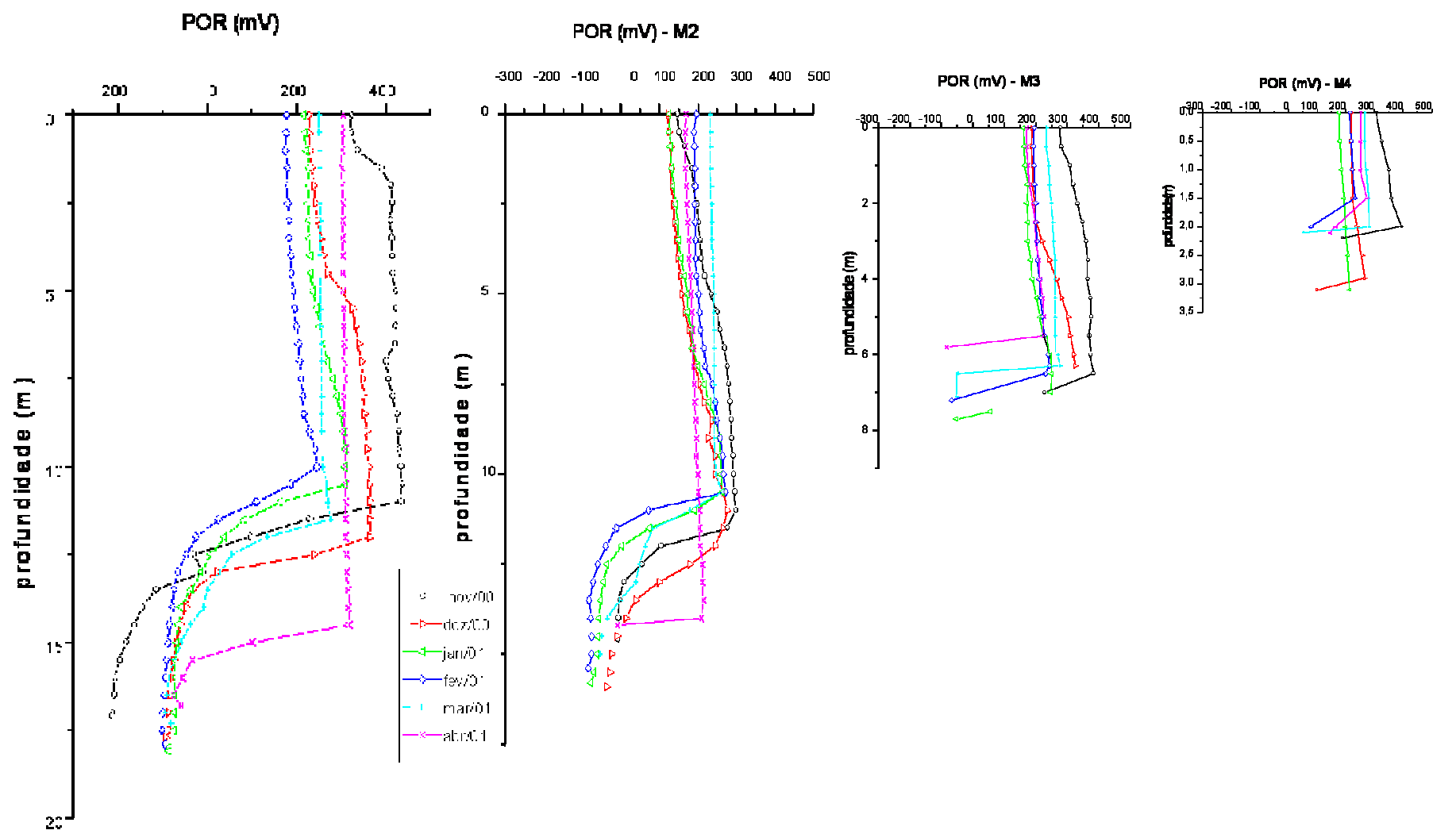

Figura 20 - Perfis verticais de potencial de oxi-redução no eixo longitudinal do reservatório nos meses em que ocorreu estratificação 
Nas Figuras 21 a 32 são apresentados os diagramas profundidade-tempo das variáveis $\mathrm{pH}$, condutividade elétrica, oxigênio dissolvido, potencial de oxi-redução, amônia e fósforo total das estações ao longo do eixo longitudinal do reservatório (M1, M2, M3 e M4) e do eixo transversal (MD, M2 e braço do Rio Claro).

Pode-se notar, em todas as variáveis apresentadas uma clara tendência à estratificação química da coluna d'água entre os meses de novembro a março e a circulação do sistema entre abril e outubro, particularmente nas estações de maior profundidade. Essa tendência se manteve, no ciclo seguinte, a julgar pelos dados de novembro/2001, apesar do grande deplecionamento do reservatório no período de estudo.

O pH no reservatório variou de 4,22 a 8,08 sendo que a estação M4 foi a que apresentou menor amplitude de variação $(5,20$ a 6,97). Os menores valores estiveram sempre associados a condições de fundo e os maiores valores à superfície.

A condutividade elétrica variou entre 27 e 290 uS/cm, com maior amplitude de variação no ponto M3 (28 a 290uS/cm). Foram registradas concentrações mais elevadas no fundo, mesmo no período de circulação completa na coluna d'água.

A variação das concentrações de oxigênio dissolvido se deu entre 0,13 a $10,71 \mathrm{mg} / \mathrm{L}$. As estações de maior profundidade apresentaram concentrações muito reduzidas em boa parte da coluna d'água na maioria das coletas.

O potencial de oxi-redução no reservatório variou de -215 a $437 \mathrm{mV}$. As condições fortemente redutoras do fundo no período de estratificação favoreceu o acúmulo de nutrientes nas águas profundas, particularmente as concentrações elevadas de amônia. 

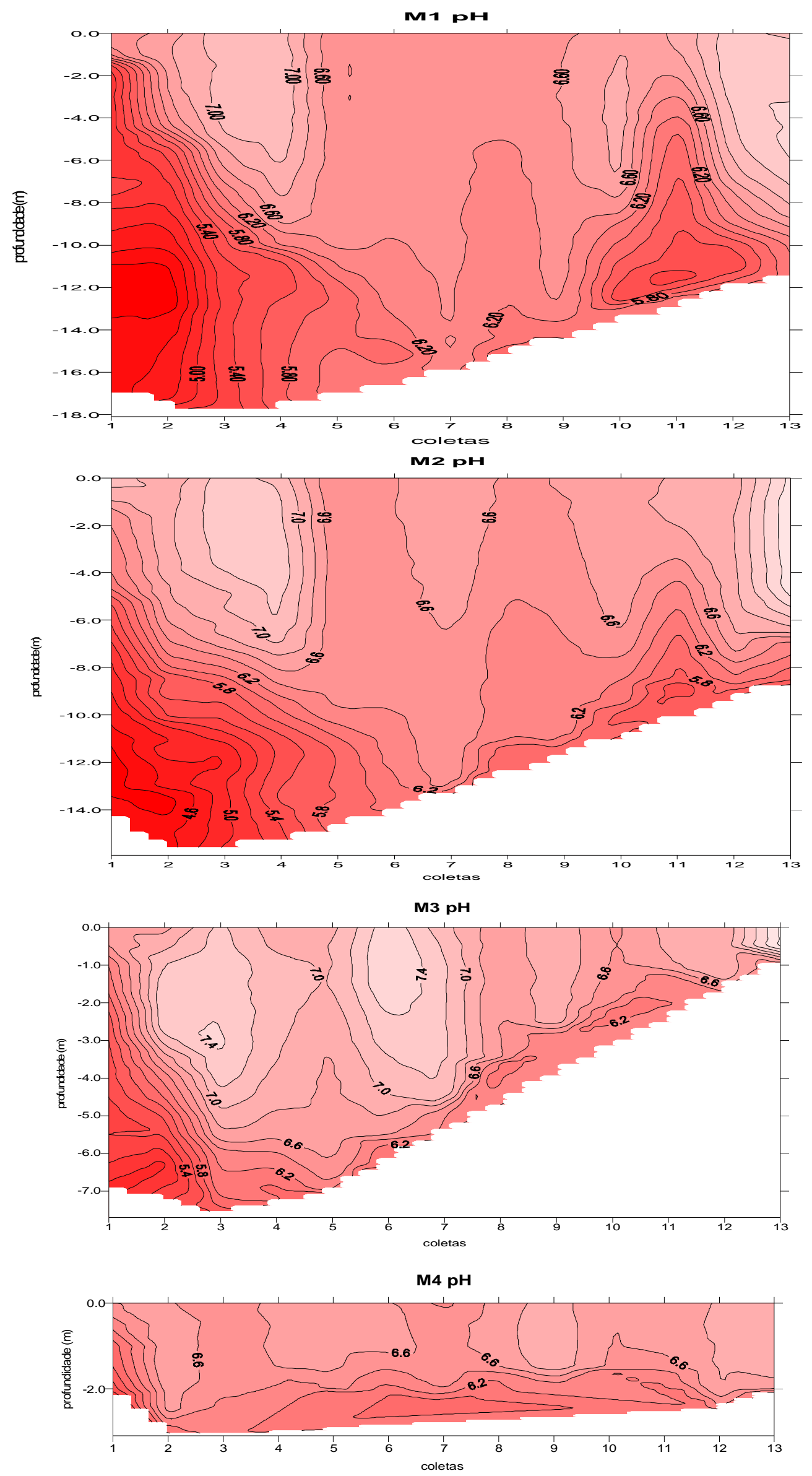

Figura 21: Diagrama profundidade-tempo do pH no eixo longitudinal do reservatório 

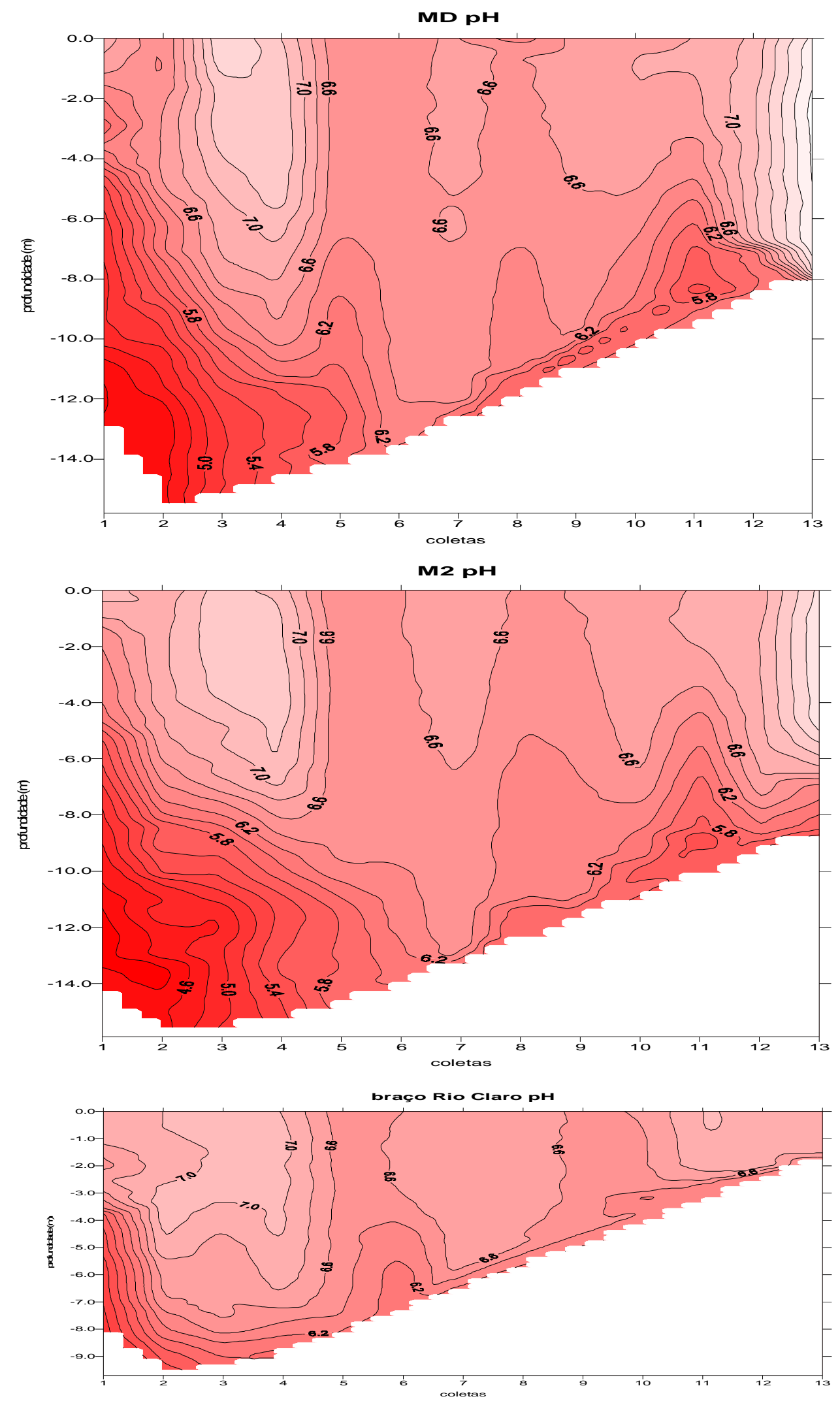

Figura 22: Diagrama profundidade-tempo do $\mathrm{pH}$ no eixo transversal do reservatório 

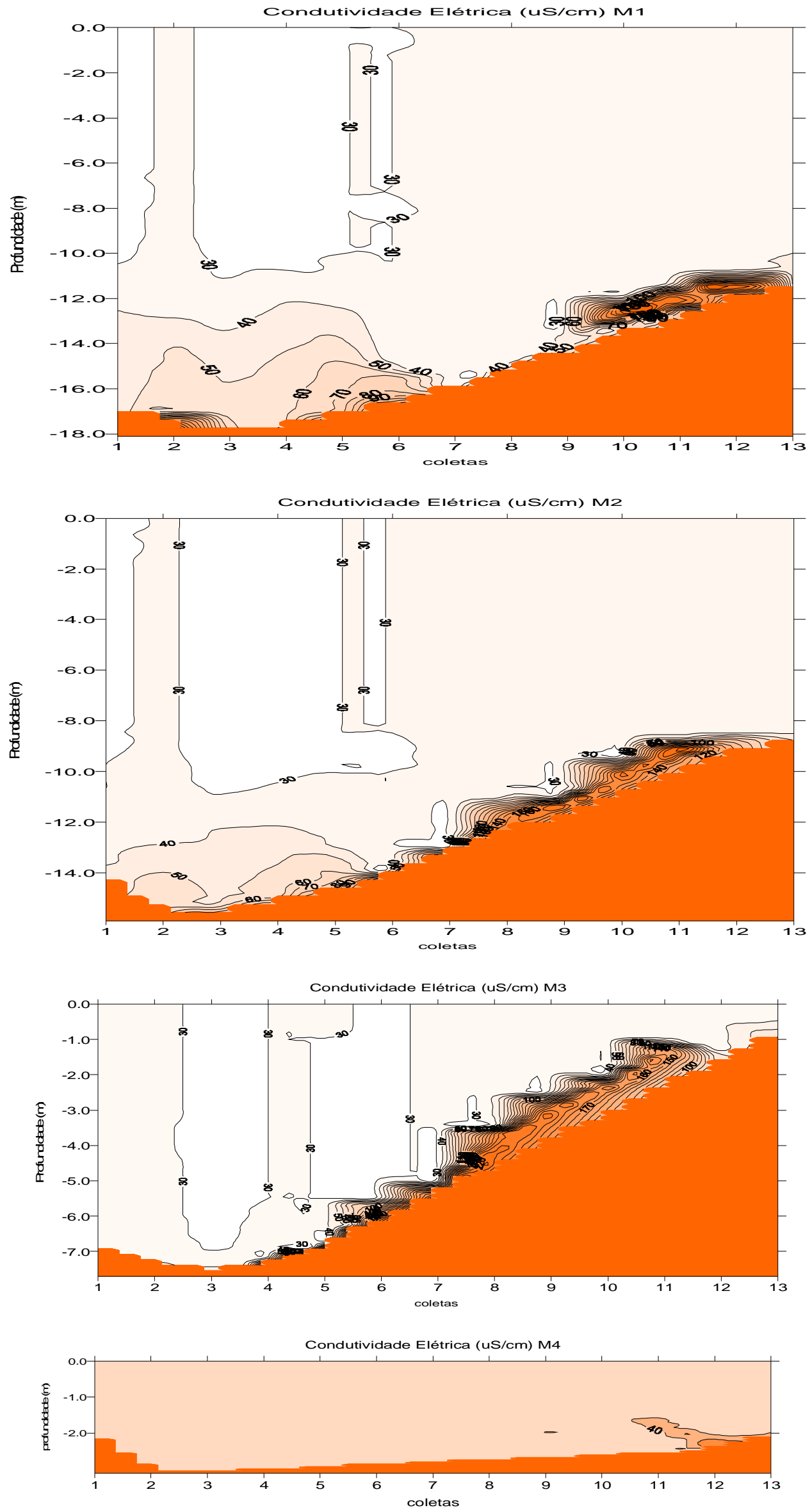

Figura 23: Diagrama profundidade-tempo da condutividade elétrica no eixo longitudinal do reservatório 

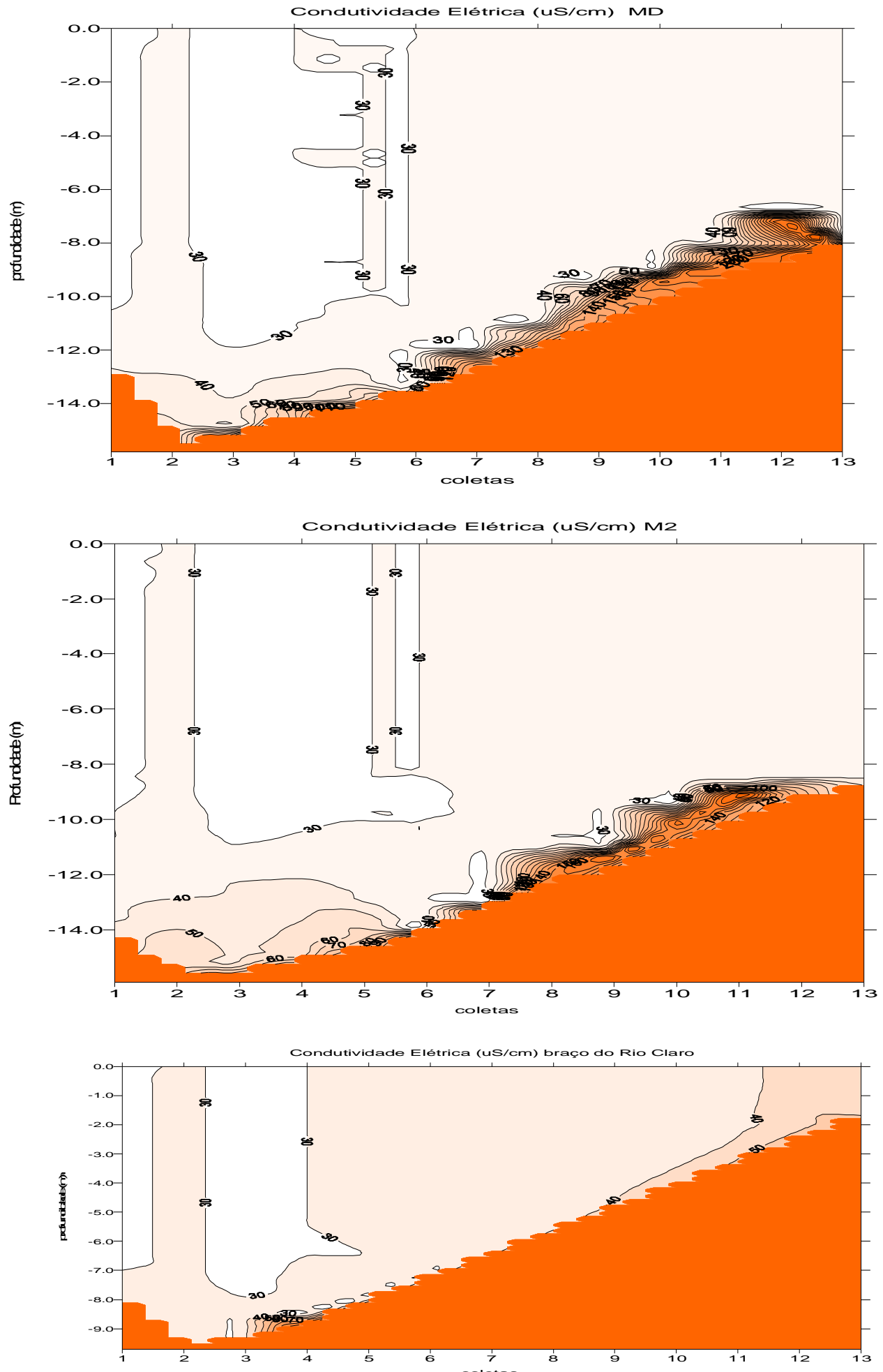

Figura 24: Diagrama profundidade-tempo da condutividade elétrica no eixo transversal do reservatório 

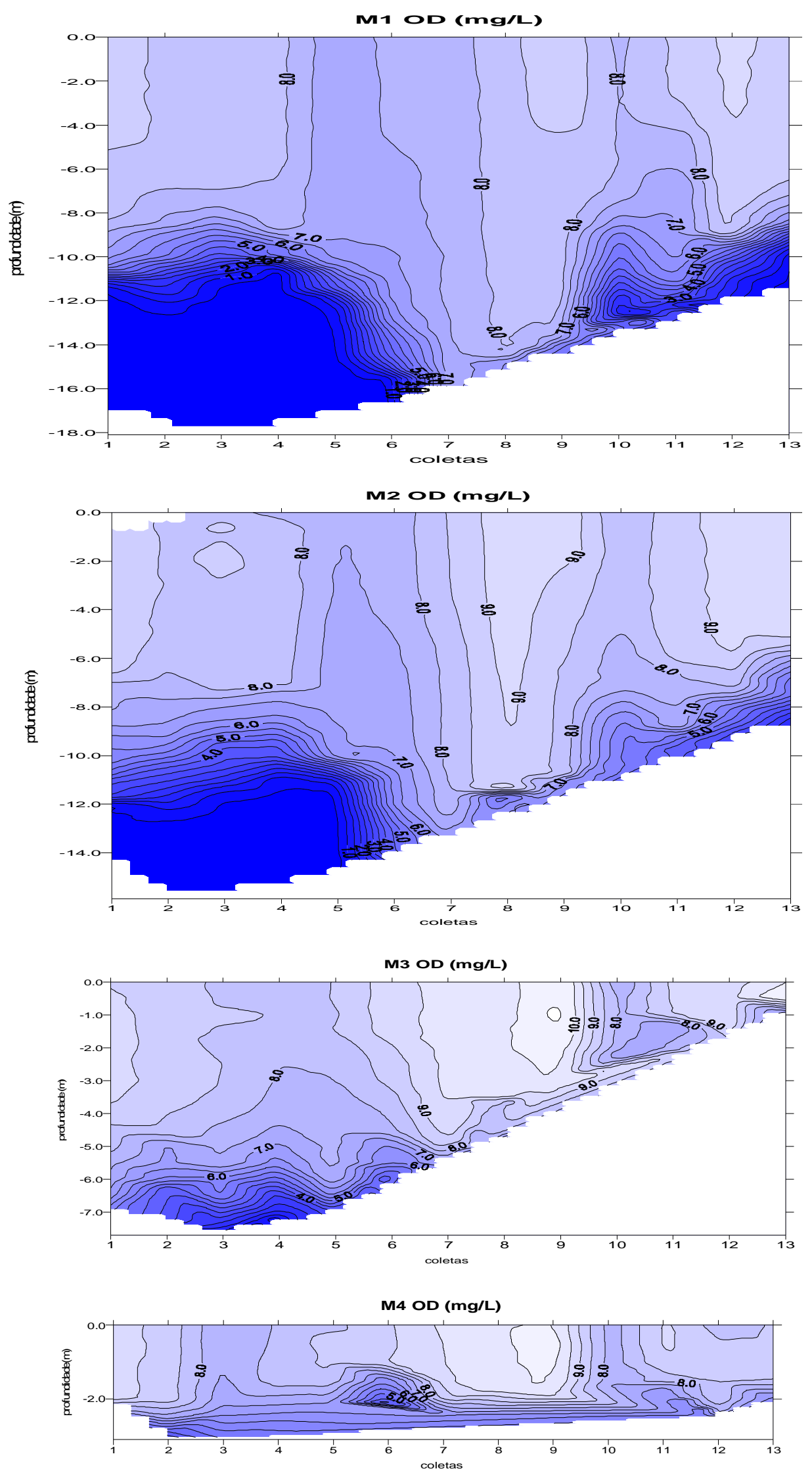

Figura 25: Diagrama profundidade-tempo do oxigênio dissolvido no eixo longitudinal do reservatório 

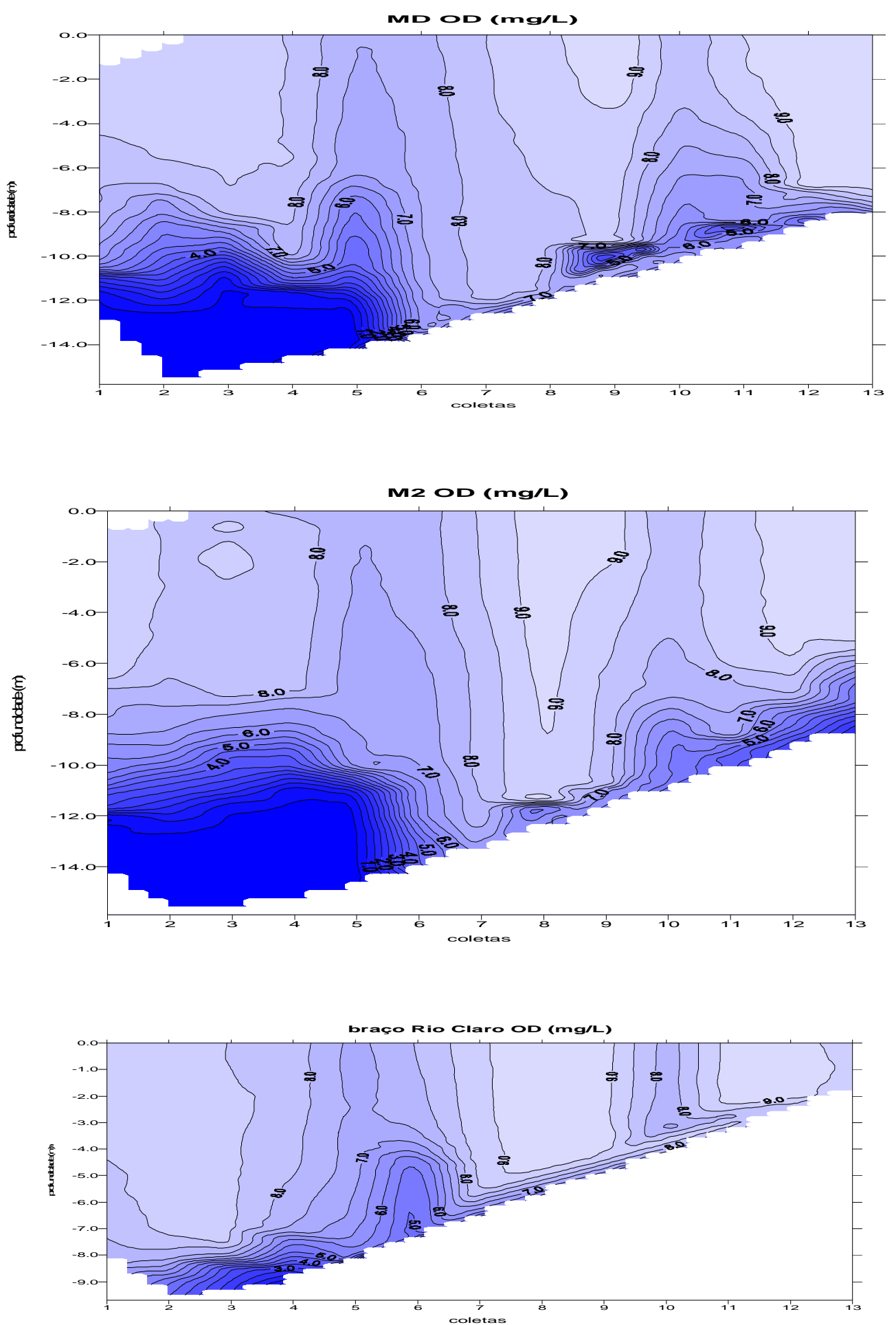

Figura 26: Diagrama profundidade-tempo do oxigênio dissolvido no eixo transversal do reservatório 

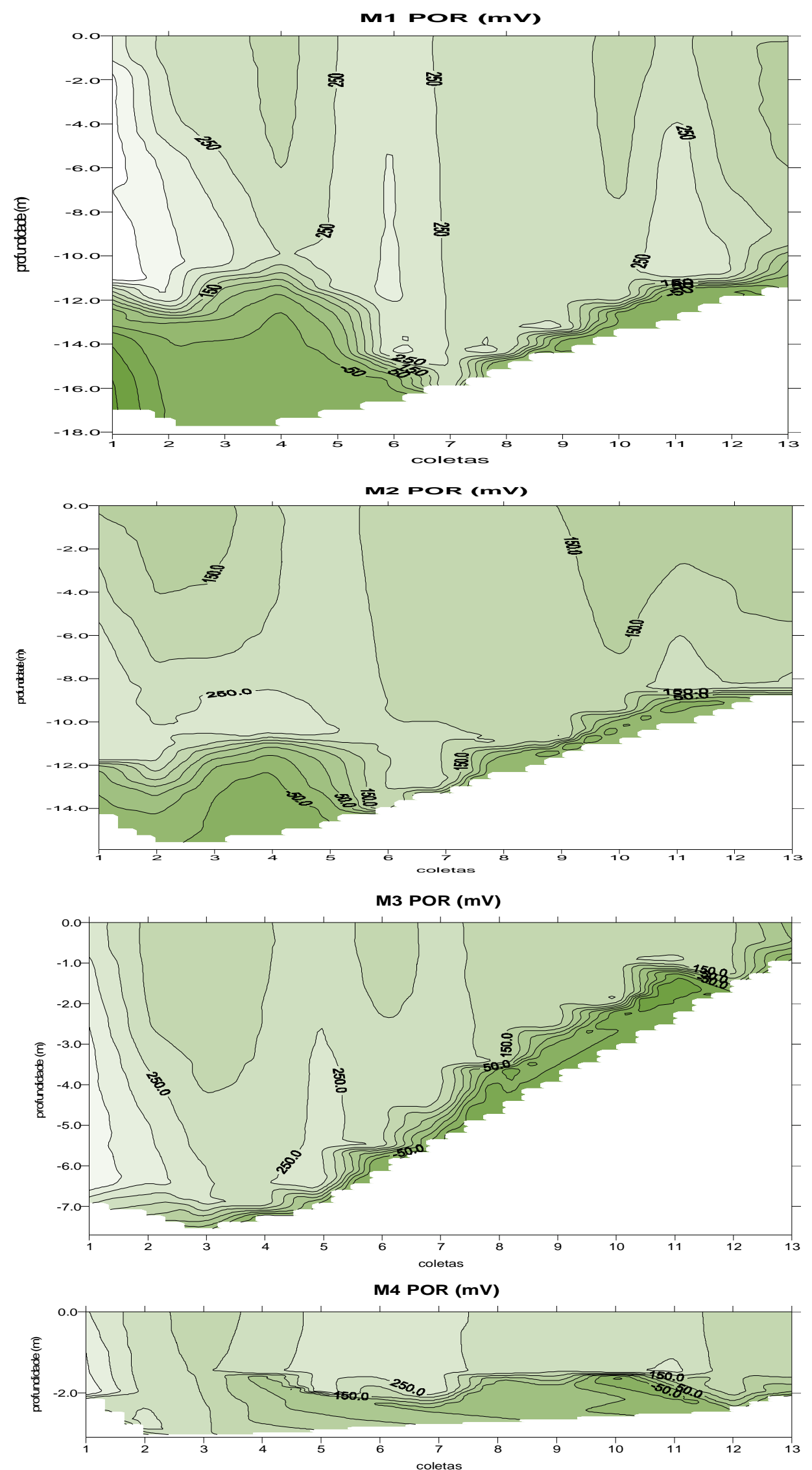

Figura 27: Diagrama profundidade-tempo do potencial de oxi-redução no eixo longitudinal do reservatório 

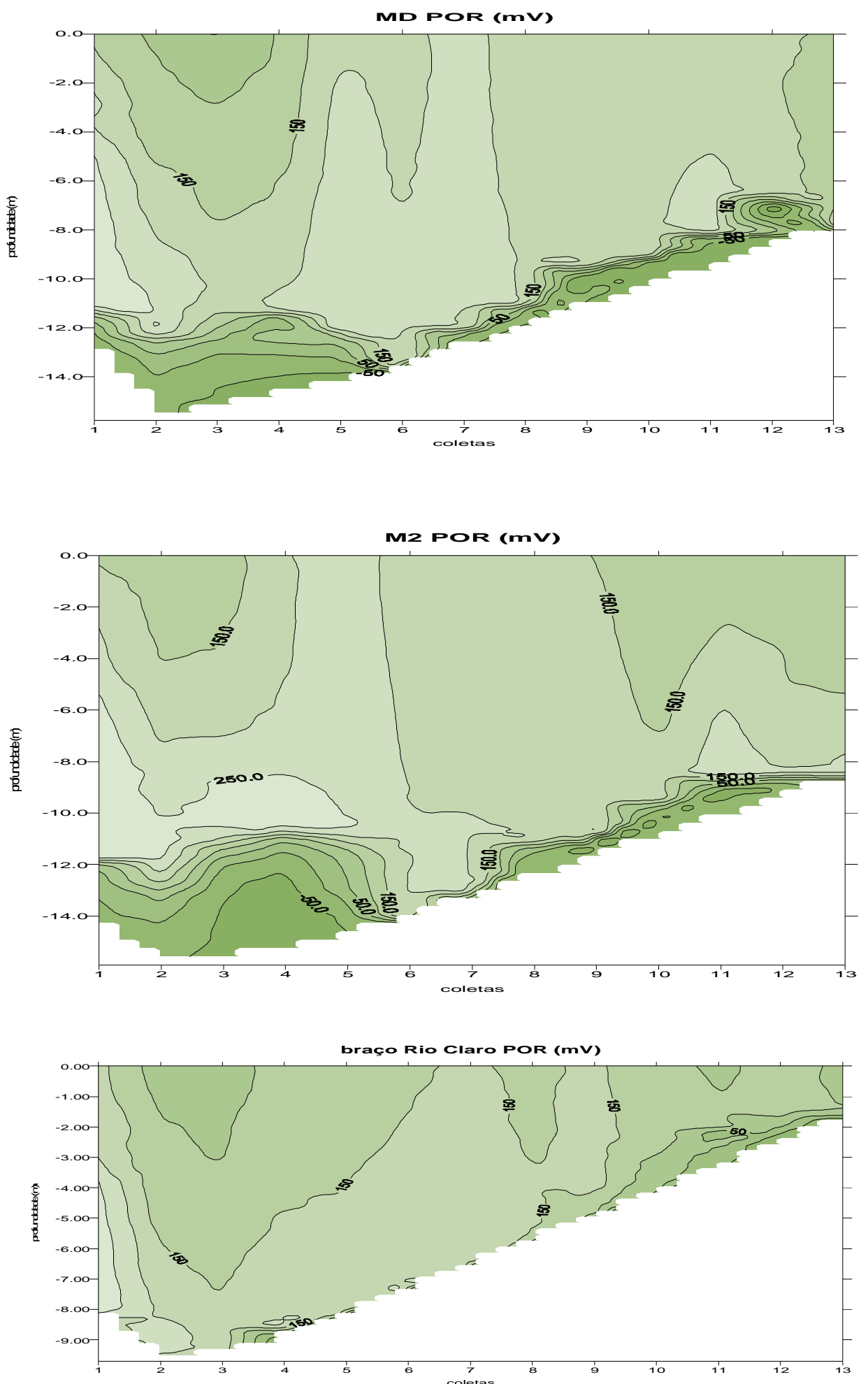

Figura 28: Diagrama profundidade-tempo do potencial de oxi-redução no eixo transversal do reservatório 

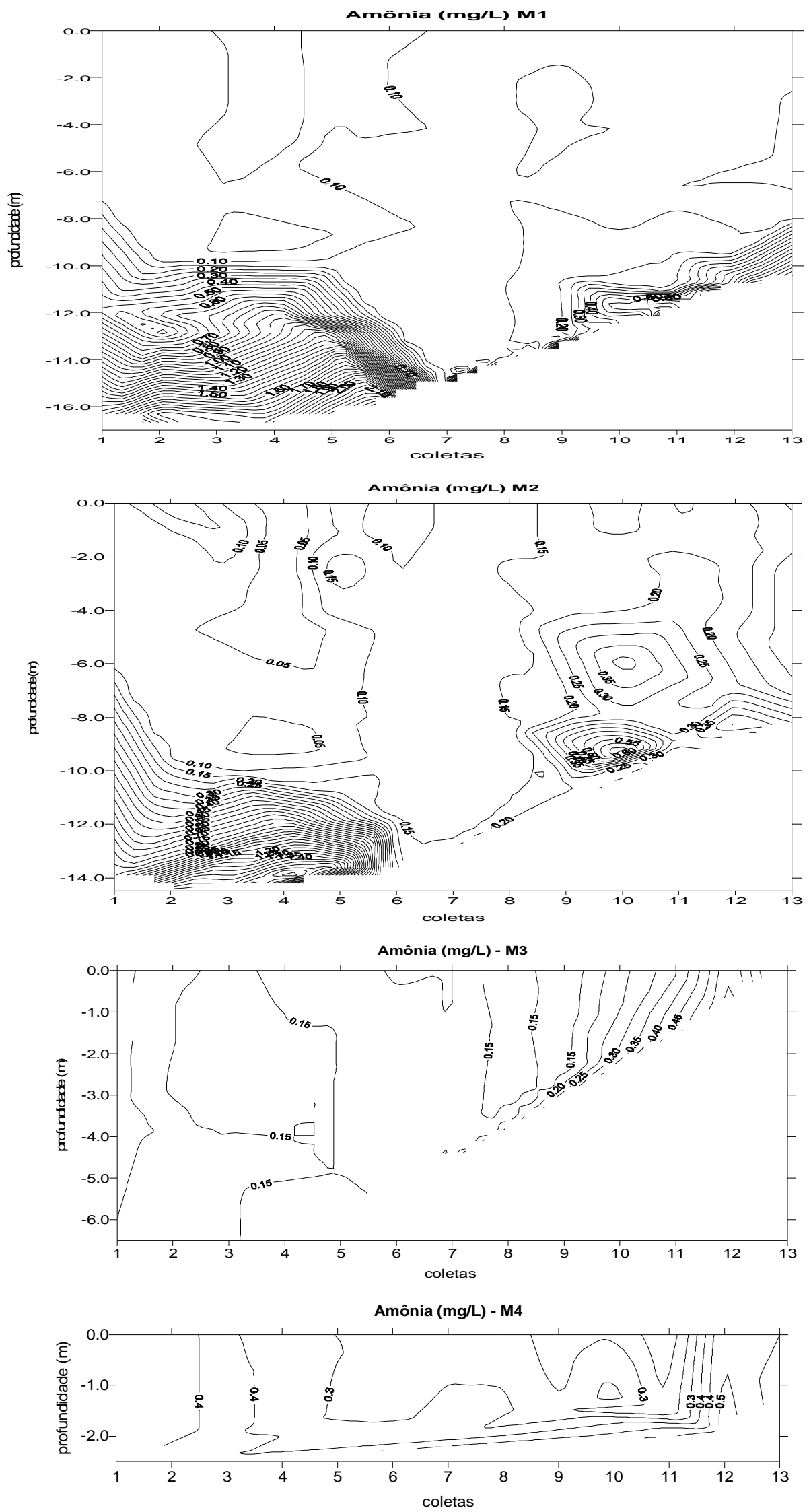

Figura 29: Diagrama profundidade-tempo de amônia no eixo longitudinal do reservatório 

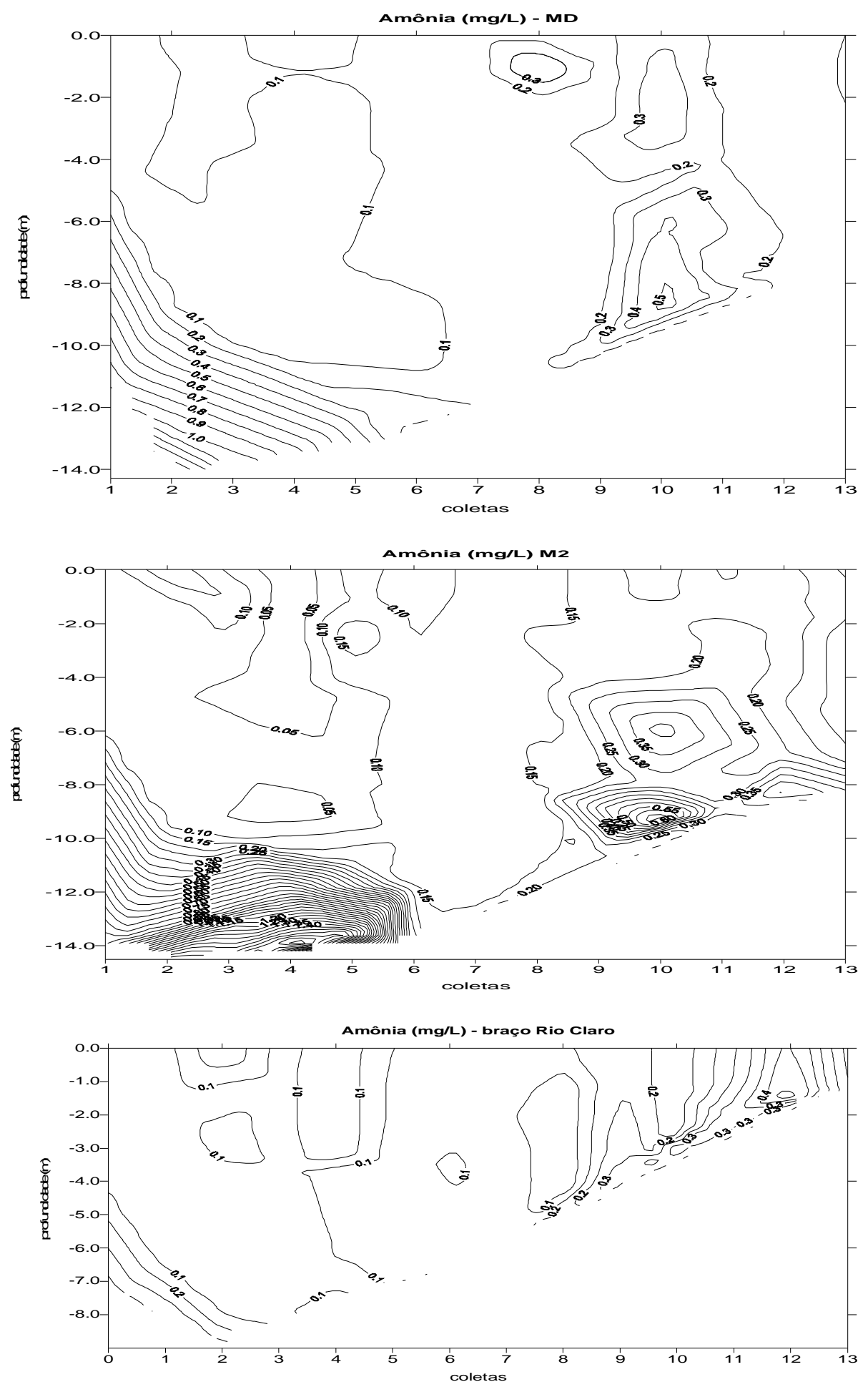

Figura 30: Diagrama profundidade-tempo de amônia no eixo transversal do reservatório 

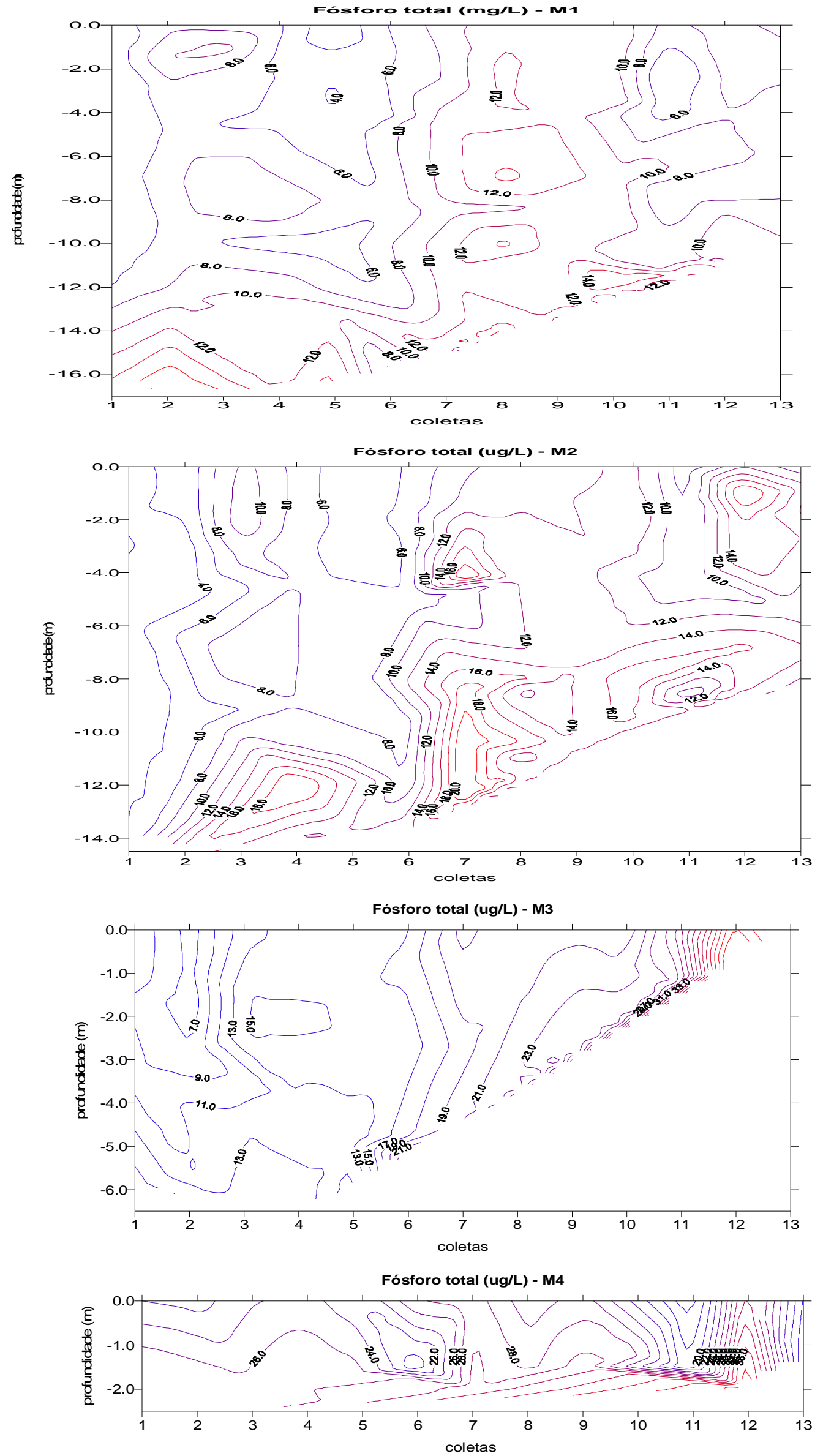

Figura 31 Diagrama profundidade-tempo do fósforo total no eixo longitudinal do reservatório 

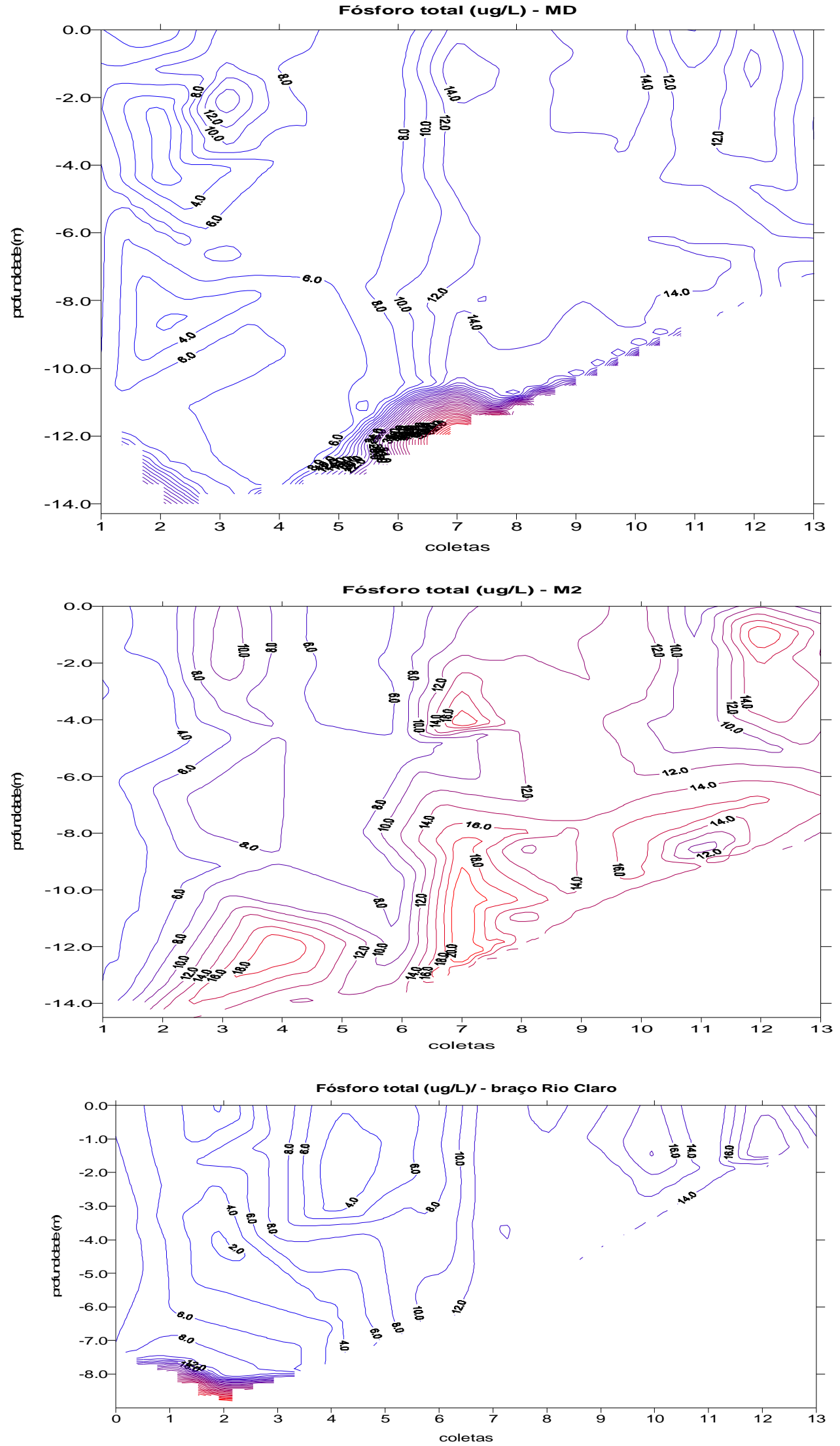

Figura 32: Diagrama profundidade-tempo do fósforo total no eixo transversal do reservatório 
4.3 Variação sazonal e compartimentação espacial no reservatório:

Na Tabela 3 são apresentados os valores médios, o desvio padrão e os coeficientes de variação das variáveis de qualidade da água analisadas nos pontos de coleta do reservatório (M1, M2, M3, M4, MD e braço do

Rio Claro), considerando todos os dados em conjunto e também separados no eixo longitudinal e transversal da represa.

Tabela 3: Valores médios, desvio padrão e coeficiente de variação de variáveis físicas, químicas e biológicas nas estações do reservatório

\begin{tabular}{|c|c|c|c|c|c|c|c|c|c|c|c|c|c|c|c|c|c|c|c|c|c|c|c|c|c|c|}
\hline & & $\mathrm{pH}$ & Cond & Tur & OD & temp & STD & POR & DurT & $\mathrm{Ca}$ & $\mathrm{Mg}$ & $\mathrm{Cl}$ & Alcal. & DBO & $\mathrm{OC}$ & Amon & Nitrito & Nitrato & $\mathrm{FeT}$ & $\mathrm{Si}$ & $\mathrm{Na}$ & $\mathrm{K}$ & STS & Pig.T & PID & PT \\
\hline & & & & & & & & & & & & & & & & & & & & & & & & & & \\
\hline \multicolumn{27}{|c|}{ RESERVATÓRIO TOTAL } \\
\hline & & & & & & & & & & & & & & & & & & & & & & & & & & \\
\hline \multirow[t]{3}{*}{ Reservatório } & Média & 6,4 & 37,0 & 10,1 & 7,0 & 22,9 & 24,2 & 170,8 & 8,0 & 1,8 & 0,9 & 4,1 & 10,6 & 0,7 & 3,8 & 0,2 & 4,1 & 5,8 & 0,4 & 0,5 & 2,1 & 1,3 & \begin{tabular}{|l|}
4,9 \\
\end{tabular} & 6,8 & 3,8 & 12,4 \\
\hline & desvio padrão & 0,7 & 24,5 & 26,8 & 2,7 & 3,2 & 16,4 & \begin{tabular}{ll|}
104,3 \\
\end{tabular} & 1,0 & 0,4 & 0,2 & 0,4 & 2,3 & 0,5 & 1,5 & 0,3 & 2,1 & 4,3 & 0,6 & 0,7 & 0,3 & 0,2 & 10,0 & 5,3 & 6,2 & 8,8 \\
\hline & CV $(\%)$ & 11 & 66 & 266 & 39 & 14 & 68 & \begin{tabular}{|l|}
61 \\
\end{tabular} & 12 & 21 & 26 & 11 & 21 & 75 & 39 & 143 & 52 & 75 & 150 & 139 & 13 & 16 & 206 & 78 & 162 & 70 \\
\hline & & & & & & & & & & & & & & & & & & & & & & & & & & \\
\hline \multicolumn{27}{|c|}{ EIXO LONGITUDINAL } \\
\hline & & & & & & & & & & & & & & & & & & & & & & & & & & \\
\hline \multirow[t]{3}{*}{ M1 } & Média & 6,1 & 38,0 & 8,3 & 6,1 & 22,2 & 25,2 & 189,2 & 8,0 & 1,8 & 0,9 & 4,2 & 10,8 & 0,7 & 3,8 & 0,3 & 3,9 & 5,2 & 0,3 & 0,3 & 2,1 & 1,2 & 3,6 & 5,8 & 3,4 & 8,9 \\
\hline & desvio padrão & 0,8 & 23,9 & 16,0 & 3,1 & 2,9 & 17,1 & 139,6 & 0,9 & 0,4 & 0,2 & 0,4 & 3,4 & 0,4 & 0,8 & 0,5 & 1,9 & 1,8 & 0,7 & 0,3 & 0,2 & 0,2 & 1,9 & 5,7 & 4,0 & 3,4 \\
\hline & $\mathrm{CV}(\%)$ & 12 & 63 & 192 & 51 & 13 & 68 & 74 & 11 & 22 & 24 & 10 & 31 & 65 & 21 & 176 & 49 & 35 & 213 & 101 & 9 & 13 & 52 & 98 & 117 & 38 \\
\hline & & & & & & & & & & & & & & & & & & & & & & & & & & \\
\hline \multirow[t]{4}{*}{$\mathrm{M} 2$} & Média & 6,3 & 36,8 & 8,1 & 6,8 & 22,7 & 23,9 & 155,9 & 7,9 & 1,7 & 0,9 & 4,1 & 10,3 & 0,6 & 3,1 & 0,2 & 4,0 & 4,8 & 0,3 & 0,3 & 2,1 & 1,3 & 3,3 & 6,0 & 4,7 & 10,6 \\
\hline & desvio padrão & 0,8 & 21,2 & 8,6 & 2,9 & 3,1 & 13,8 & 86,1 & 0,8 & 0,4 & 0,2 & 0,4 & 2,1 & 0,4 & 0,9 & 0,4 & 1,8 & 1,7 & 0,6 & 0,2 & 0,2 & 0,2 & 2,0 & 4,6 & 11,8 & 4,7 \\
\hline & CV (\%) & 12 & 58 & 107 & 43 & 14 & 58 & 55 & 10 & 20 & 25 & 10 & 20 & 71 & 30 & 149 & 45 & 36 & 187 & 81 & 9 & 12 & 62 & 77 & 252 & 44 \\
\hline & & & & & & & & & & & & & & & & & & & & & & & & & & \\
\hline \multirow[t]{4}{*}{ M3 } & Média & 6,7 & 40,5 & 10,1 & 8,0 & 24,2 & 26,5 & 192,7 & 7,8 & 1,7 & 0,9 & 3,9 & 10,3 & 0,9 & 4,0 & 0,2 & 3,6 & 4,8 & 0,5 & 0,7 & 2,1 & 1,4 & 5,5 & 10,1 & 3,4 & 17,9 \\
\hline & desvio padrão & 0,6 & 40,1 & 11,7 & 1,9 & 3,4 & 26,1 & 110,5 & 0,4 & 0,3 & 0,2 & 0,5 & 1,5 & 0,5 & 1,1 & 0,1 & 1,9 & 1,7 & 0,2 & 0,5 & 0,3 & 0,2 & 3,5 & 3,8 & 2,8 & 9,8 \\
\hline & CV (\%) & 9 & 99 & 116 & 24 & 14 & 99 & \begin{tabular}{|l|}
57 \\
\end{tabular} & 6 & 17 & 20 & 12 & 14 & 58 & 27 & 67 & 53 & 36 & 50 & 70 & 14 & \begin{tabular}{|l|}
17 \\
\end{tabular} & 62 & 38 & 81 & 55 \\
\hline & & & & & & & & & & & & & & & & & & & & & & & & & & \\
\hline \multirow[t]{3}{*}{ M4 } & Média & 6,5 & 34,7 & 22,9 & 8,1 & 22,9 & 22,5 & 198,5 & 8,3 & 1,7 & 1,0 & 3,8 & 12,0 & 1,3 & 6,9 & 0,3 & 5,1 & 6,5 & 1,6 & 2,7 & 2,6 & 1,6 & 6,7 & 14,1 & 4,7 & 25,2 \\
\hline & desvio padrão & 0,3 & 4,7 & 44,7 & 1,5 & 3,7 & 3,0 & 92,4 & 0,8 & 0,3 & 0,2 & 0,7 & 1,4 & 0,5 & 1,8 & 0,1 & 2,5 & 2,8 & 0,4 & 0,7 & 0,5 & 0,3 & 2,0 & 5,5 & 3,0 & 5,9 \\
\hline & CV (\%) & 5 & 14 & 196 & 19 & 16 & 13 & 47 & 10 & 17 & 22 & 19 & 12 & 40 & 27 & 21 & 49 & 43 & 25 & 24 & \begin{tabular}{|l|}
18 \\
\end{tabular} & 16 & 30 & 39 & 63 & 23 \\
\hline & & & & & & & & & & & & & & & & & & & & & & & & & & \\
\hline \multicolumn{27}{|c|}{ EIXO TRANSVERSAL } \\
\hline & & & & & & & & & & & & & & & & & & & & & & & & & & \\
\hline \multirow[t]{3}{*}{$\mathrm{MD}$} & Média & 6,4 & 37,1 & 8,3 & 7,1 & 23,0 & 24,1 & 159,2 & 7,9 & 1,8 & 0,8 & 4,1 & 10,5 & 0,5 & 3,4 & 0,2 & 4,4 & 5,3 & 0,3 & 0,3 & 2,1 & 1,3 & 6,6 & 5,6 & 3,5 & 11,8 \\
\hline & desvio padrão & 0,8 & 27,3 & 16,5 & 2,6 & 3,2 & 17,8 & 79,6 & 1,2 & 0,3 & 0,3 & 0,4 & 1,7 & 0,4 & 1,4 & 0,2 & 2,6 & 2,1 & 0,5 & 0,2 & 0,2 & 0,2 & 19,6 & 4,8 & 2,5 & 10,0 \\
\hline & CV (\%) & 12 & 74 & 197 & 37 & 14 & \begin{tabular}{|l|}
74 \\
\end{tabular} & 50 & 15 & 20 & 34 & \begin{tabular}{|l|}
9 \\
\end{tabular} & 16 & 80 & 41 & 118 & 60 & 39 & 170 & 77 & 9 & 14 & 299 & 87 & 73 & 85 \\
\hline & & & & & & & & & & & & & & & & & & & & & & & & & & \\
\hline \multirow[t]{4}{*}{ M2 } & Média & 6,3 & 36,8 & 8,1 & 6,8 & 22,7 & 23,9 & 155,9 & 7,9 & 1,7 & 0,9 & 4,1 & 10,3 & 0,6 & 3,1 & 0,2 & 4,0 & 4,8 & 0,3 & 0,3 & 2,1 & 1,3 & 3,3 & 6,0 & 4,7 & 10,6 \\
\hline & desvio padrão & 0,8 & 21,2 & 8,6 & 2,9 & 3,1 & 13,8 & 86,1 & 0,8 & 0,4 & 0,2 & 0,4 & 2,1 & 0,4 & 0,9 & 0,4 & 1,8 & 1,7 & 0,6 & 0,2 & 0,2 & 0,2 & 2,0 & 4,6 & 11,8 & 4,7 \\
\hline & CV $(\%)$ & 12 & 58 & 107 & 43 & 14 & 58 & 55 & 10 & 20 & 25 & 10 & 20 & 71 & 30 & 149 & 45 & 36 & 187 & 81 & 9 & 12 & 62 & 77 & 252 & 44 \\
\hline & & & & & & & & & & & & & & & & & & & & & & & & & & \\
\hline braço & Média & 6,6 & 33,4 & 16,3 & 7,9 & 23,7 & 21,7 & 148,4 & 8,4 & 1,9 & 0,9 & 4,3 & 10,4 & 0,4 & 3,6 & 0,1 & 4,0 & 9,5 & 0,3 & 0,4 & 2,0 & 1,2 & 5,3 & 5,2 & 3,8 & 11,2 \\
\hline \multirow[t]{2}{*}{ Rio Claro } & desvio padrão & 0,5 & 12,2 & 61,5 & 1,6 & 3,0 & 8,0 & 54,8 & 1,3 & 0,5 & 0,2 & 0,4 & 1,6 & 0,4 & 1,4 & 0,1 & 2,0 & 9,7 & 0,3 & 0,3 & 0,2 & 0,2 & 9,2 & 3,2 & 3,9 & 10,3 \\
\hline & CV (\%) & 7 & 37 & 377 & 20 & 12 & 37 & 37 & 15 & 25 & 22 & 10 & 15 & 102 & 39 & 71 & 49 & 102 & 100 & 73 & 9 & 15 & 174 & 62 & 102 & 93 \\
\hline
\end{tabular}

Nas Figuras 33 a 36 são mostradas a média e o desvio-padrão de algumas das variáveis estudadas no eixo longitudinal e no eixo vertical do reservatório, considerando o período seco (abril a setembro e o período chuvoso (outubro a março). 
Os resultados indicam, ao longo do reservatório, uma tendência de aumento da turbidez, dos sólidos totais em suspensão, do fósforo total, da sílica reativa, do ferro total, do oxigênio dissolvido e dos pigmentos totais. Em relação à condutividade elétrica e ao potencial de oxi-redução não se observou um padrão definido de comportamento.

No eixo transversal foram observadas algumas diferenças entre as margens e destas em relação ao corpo central, particularmente quanto aos sólidos em suspensão, e à turbidez.

Nas Figuras 37 e 38 é apresentada a variação sazonal da amônia, do nitrato, do fosfato inorgânico dissolvido e do fósforo total na superfície e no fundo das estações do reservatório.

Diferenças evidentes nas concentrações de superfície e fundo são notadas principalmente no período de estratificação do reservatório, principalmente nas estações com maior profundidade (M1, M2 e MD). Um outro aspecto relevante a ser ressaltado é aumento evidente das concentrações ao longo do tempo na estação M3, justamente a que maior variação relativa de profundidade apresentou ao longo do período de estudo, com redução de mais de $70 \%$ ao longo dos estudos. 

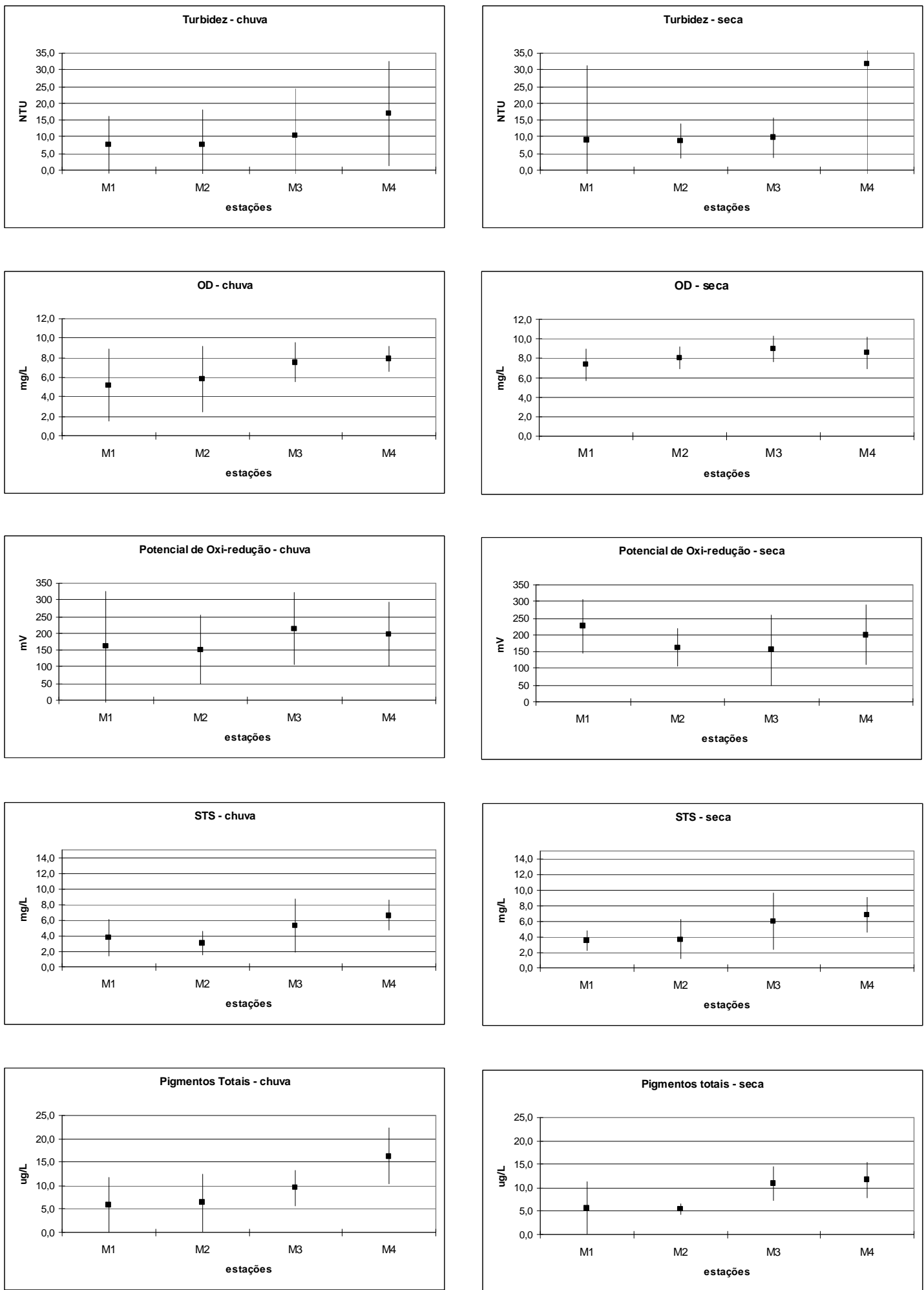

Figura 33: Média e desvio-padrão dos valores de turbidez, oxigênio dissolvido, potencial de oxi-redução, sólidos totais em suspensão e pigmentos totais nas estações ao longo do eixo longitudinal do reservatório. 

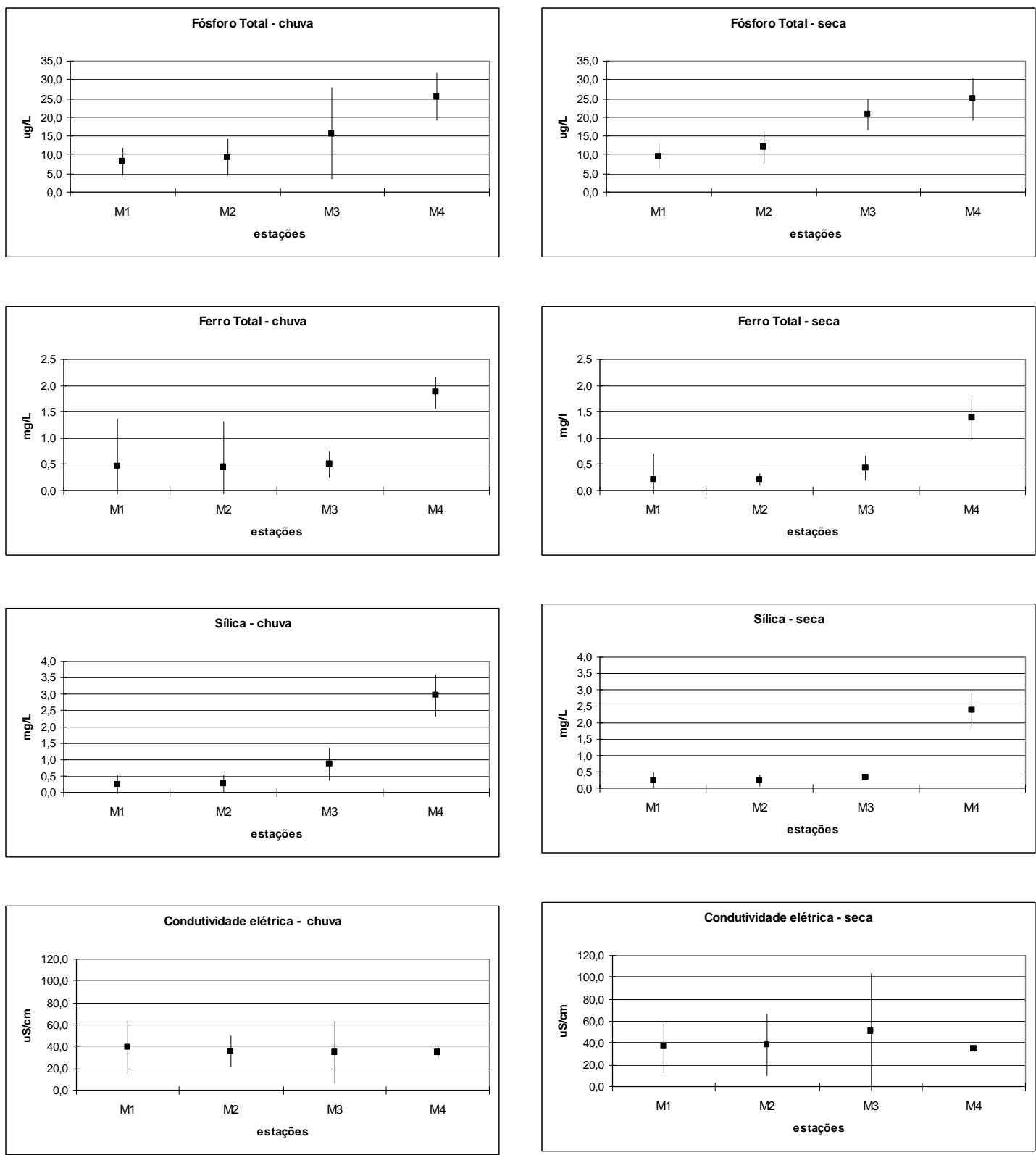

Figura 34: Média e desvio-padrão dos valores de fósforo total, ferro total, sílica reativa e condutividade elétrica nas estações ao longo do eixo longitudinal do reservatório. 

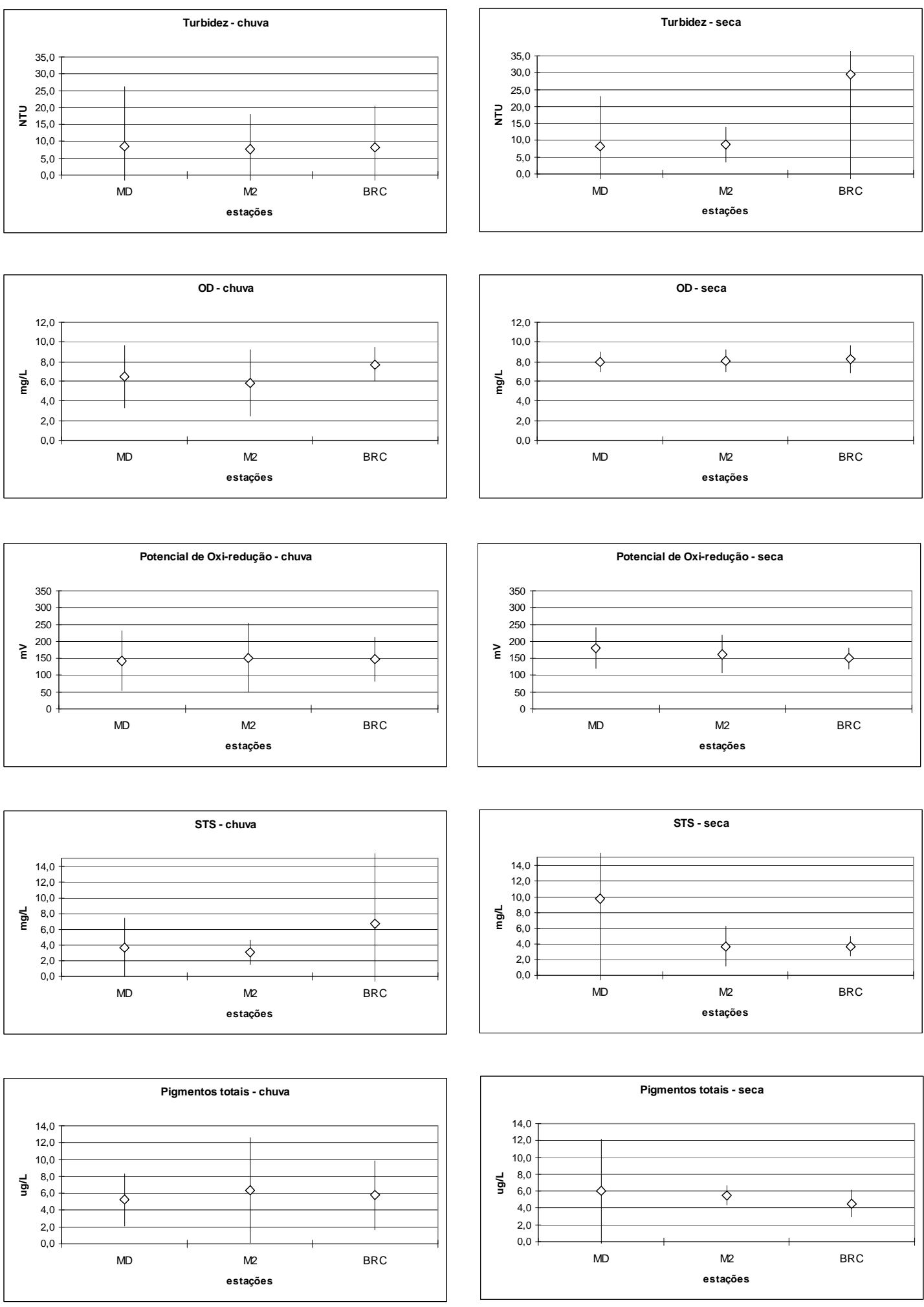

Figura 35: Média e desvio-padrão dos valores de turbidez, oxigênio dissolvido, potencial de oxi-redução, sólidos totais em suspensão e pigmentos totais nas estações ao longo do eixo longitudinal do reservatório 

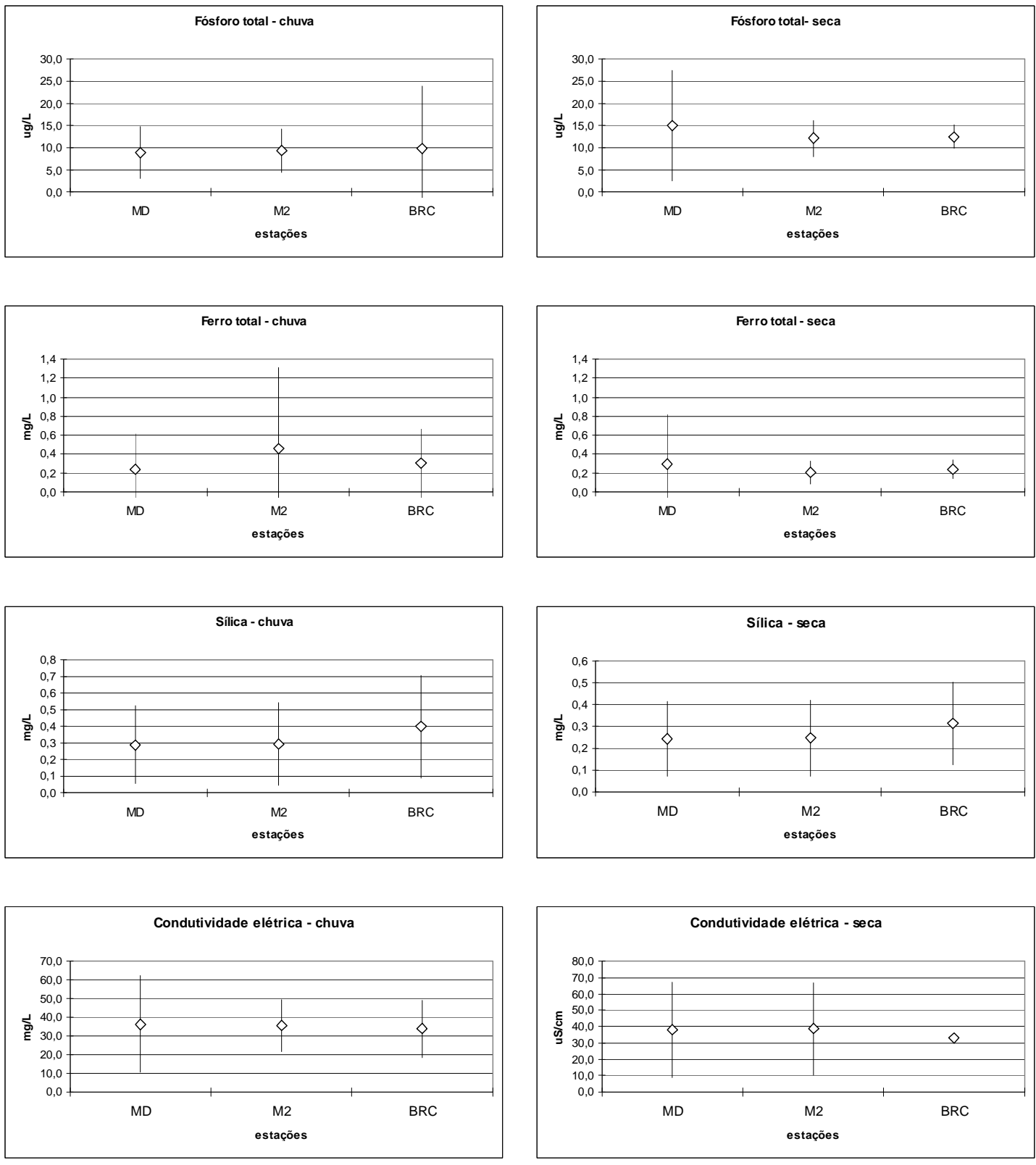

Figura 36: Média e desvio-padrão dos valores de fósforo total, ferro total, sílica reativa e condutividade elétrica nas estações ao longo do eixo transversal do reservatório. 

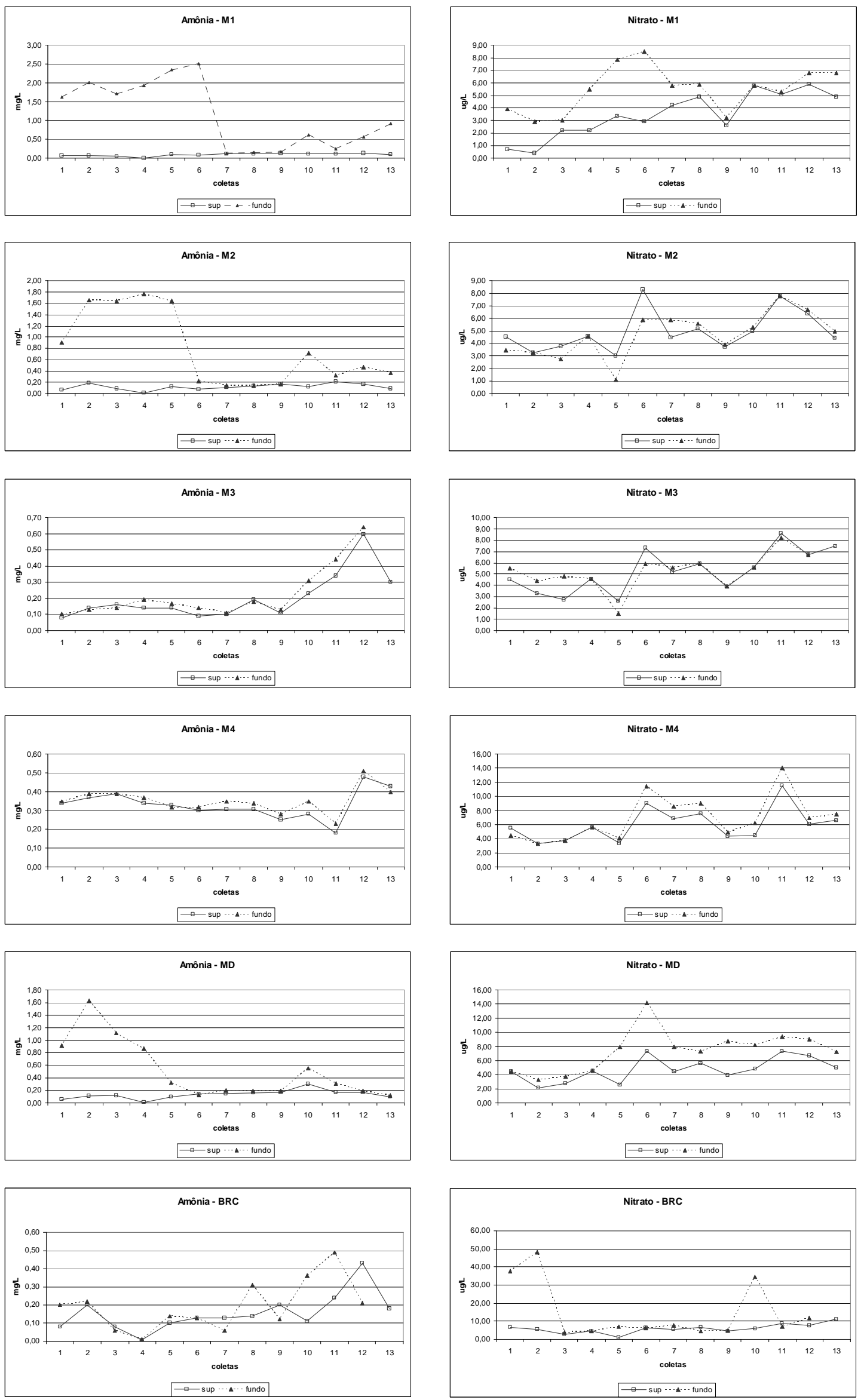

Figura 37: Variação temporal na superfície e fundo de amônia e nitrato nas estações do reservatório 

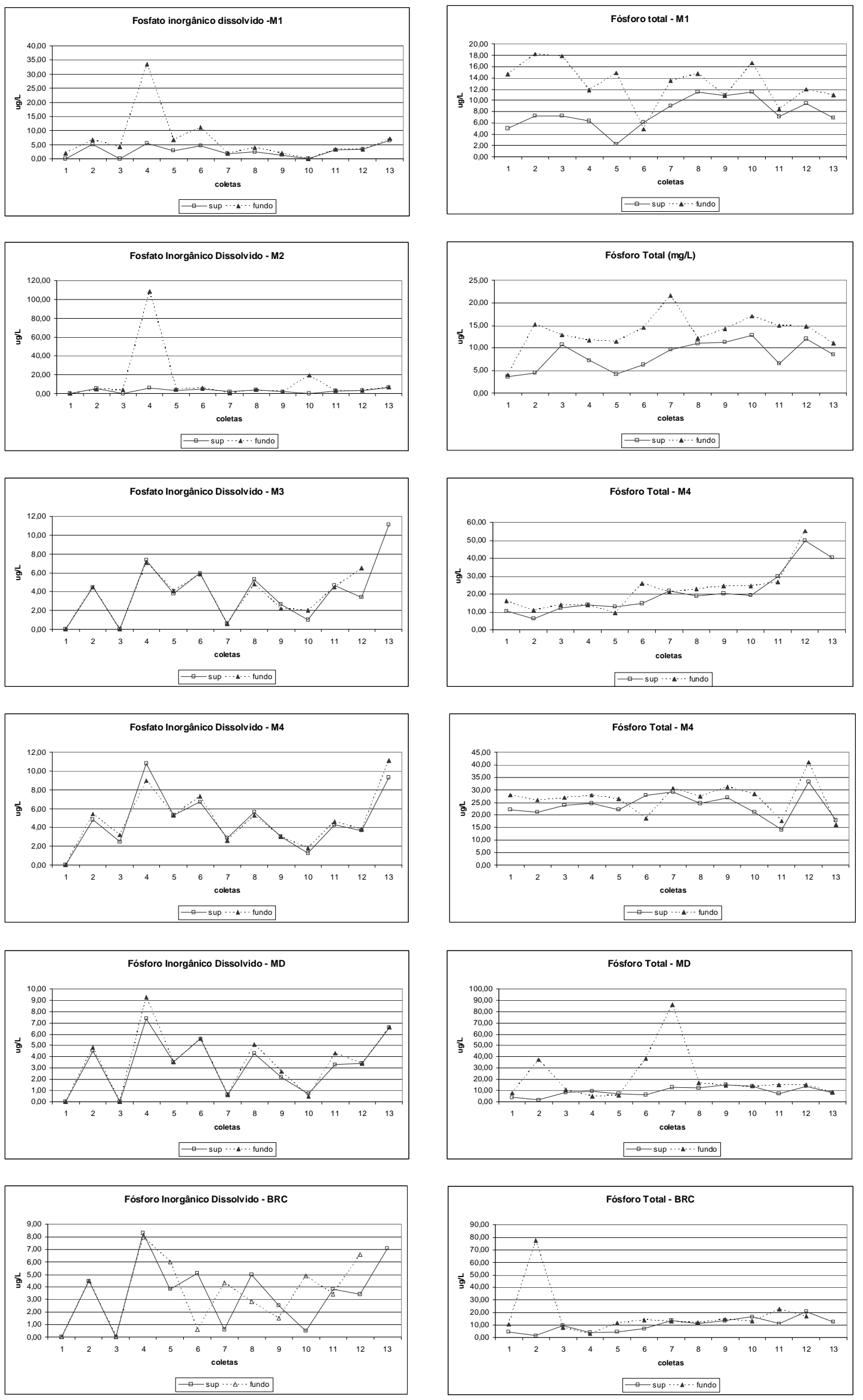

Figura 38 Variação temporal na superfície e fundo de fosfato dissolvido e fósforo total nas estações do reservatório 
Nas Figuras 39 e 40 é mostrada a variabilidade dos valores médios de temperatura, $\mathrm{pH}$, condutividade elétrica, oxigênio dissolvido e potencial de oxi-redução nos pontos M1 a M4. Temperatura e oxigênio dissolvido foram as variáveis que apresentaram um padrão sazonal mais evidente e o potencial de oxi-redução o que apresentou maior variabilidade dos valores médios na coluna d'água, de até $106 \%$. 

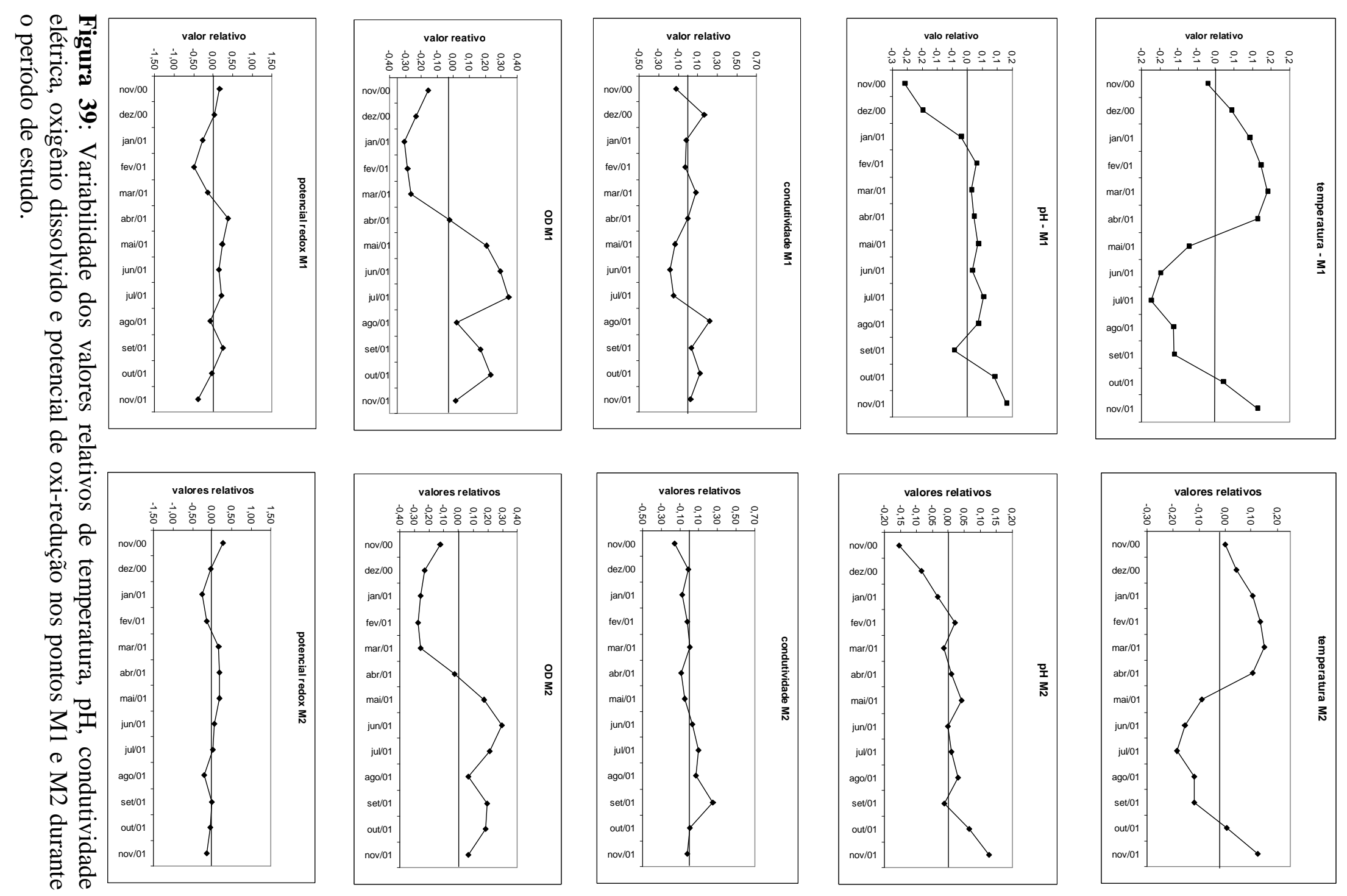

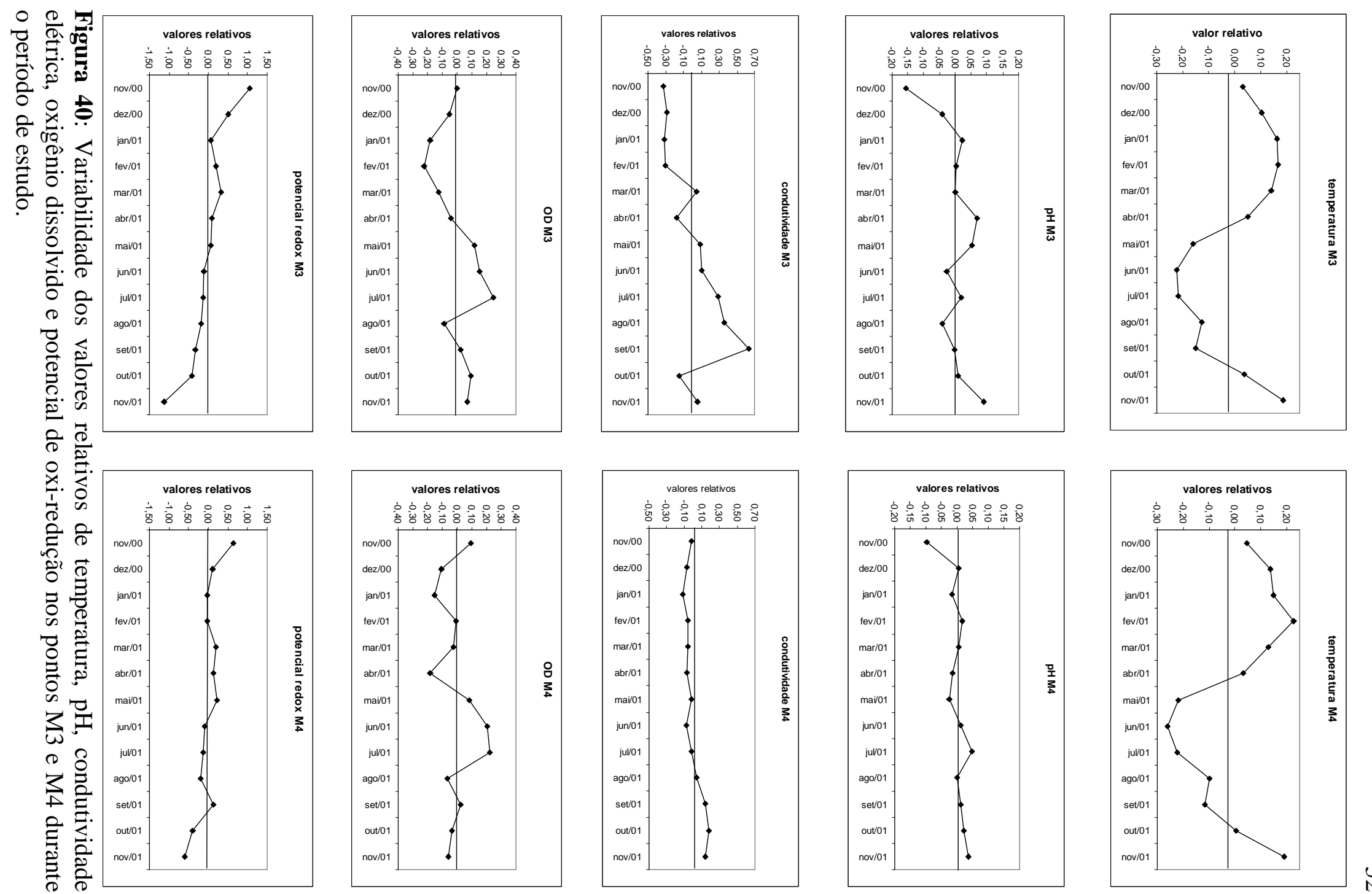
Para avaliar as principais tendências de variação dos fatores limnológicos, considerando os valores médios na coluna d'água ao longo do tempo (13 coletas) e os pontos de coleta do reservatório, separados em eixo longitudinal e eixo transversal, foi realizada uma análise multivariada exploratória.

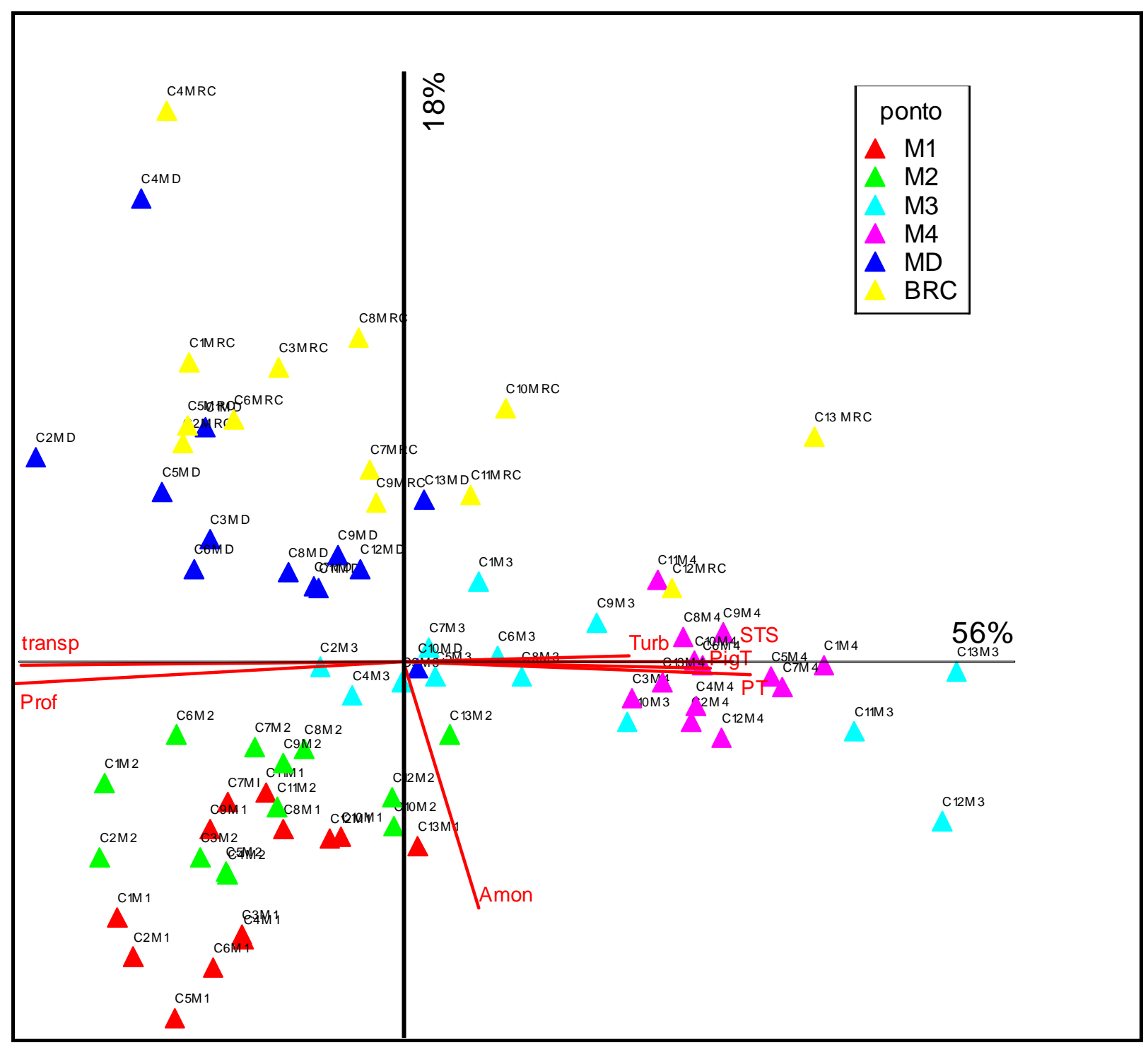

Figura 41 "Biplot" da ACP com a ordenação nos eixos 1 e 2 dos pontos de amostragem no reservatório em 12 amostragens.

A análise do conjunto de estações do reservatório resumiu $74 \%$ da variabilidade das médias em seus dois primeiros eixos de ordenação (Figura 41). A tabela das variáveis com os eixos da ACP (Tabela 4) permitiu observar que a separação das estações de amostragem esteve 
relacionada à profundidade e à transparência e às variáveis a elas associadas como turbidez, STS, fósforo total e pigmentos totais. Por sua vez a amônia foi a principal responsável pela separação dos pontos mais profundos das estações das margens (MD e BRC).

Tabela 4 : Correlação das variáveis nas estações do reservatório com os componentes principais 1 e 2

\begin{tabular}{lcc}
\hline & Autovetores & \\
\hline & $\mathbf{1}$ & $\mathbf{2}$ \\
\hline profundidade & $-0,4371$ & $-0,1843$ \\
\hline transparência & $-0,4287$ & $-0,0766$ \\
\hline turbidez & 0,392 & 0,0951 \\
\hline amônia & 0,1912 & $-0,6134$ \\
\hline STS & 0,3987 & 0,0240 \\
\hline P total & 0,4087 & $-0,1404$ \\
\hline Pigmentos totais & 0,3848 & $-0,0971$ \\
\hline
\end{tabular}

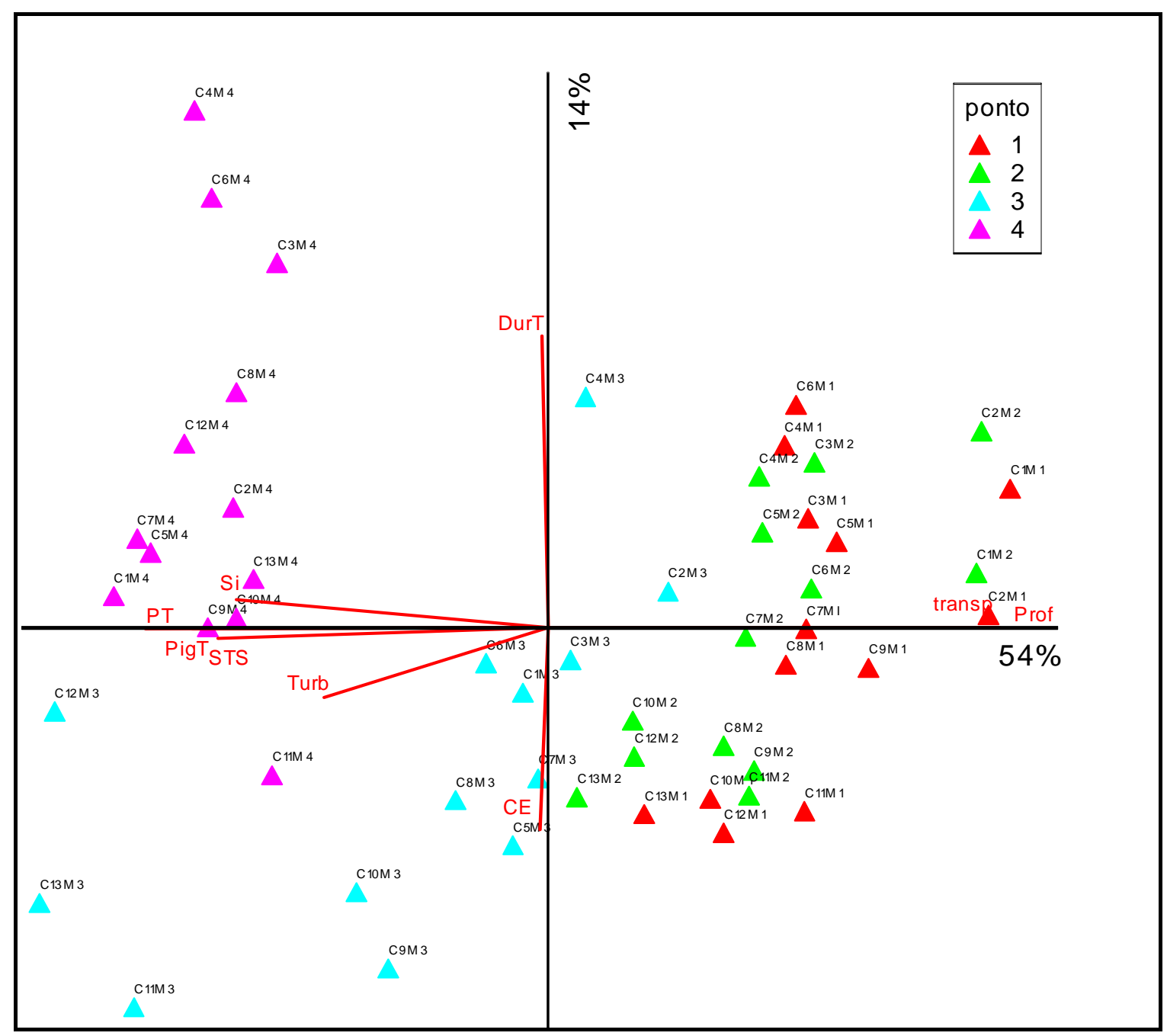


Figura 42 "Biplot" da ACP com a ordenação nos eixos 1 e 2 dos pontos de amostragem no eixo longitudinal do reservatório em 12 amostragens.

Tabela 5 : Correlação das variáveis no eixo longitudinal com os componentes principais 1 e 2 .

\begin{tabular}{lcc}
\hline & Autovetores & \\
\hline profundidade & $\mathbf{1}$ & $\mathbf{2}$ \\
\hline transparência & 0,3959 & $-0,0048$ \\
\hline condutividade elétrica & 0,3739 & 0,0106 \\
\hline turbidez & $-0,0525$ & $-0,5347$ \\
\hline dureza total & $-0,2785$ & 0,3142 \\
\hline amônia & $-0,0491$ & 0,6408 \\
\hline STS & $-0,0985$ & 0,3436 \\
\hline P total & $-0,3381$ & $-0,1247$ \\
\hline pigmentos totais & $-0,3735$ & $-0,406$ \\
\hline sílica reativa & $-0,3516$ & $-0,0423$ \\
\hline
\end{tabular}

A análise no eixo longitudinal do reservatório (Figura 42) resumiu 68\% da variação observada nos dois primeiros eixos de ordenação. Houve uma clara separação dos pontos mais próximos à barragem (M1 e M2) dos mais distantes em função da profundidade e transparência, cujos valores aumentaram a partir de montante para jusante e da turbidez, STS, fósforo total, pigmentos totais e sílica, cujos valores diminuíram nesse sentido.

A análise no eixo transversal do reservatório (Figura 43 e Tabela 6) explicou $61 \%$ da variação observada nos dois primeiros eixos de ordenação. Nessa análise, a amônia representou um papel importante na separação do corpo central (M2) dos pontos das margens e mostrou a maior semelhança do ponto da margem direita (MD) em relação ao corpo central do que o ponto da margem esquerda (BRC), que, por sinal, recebe a influência da entrada do Rio Claro no reservatório. 


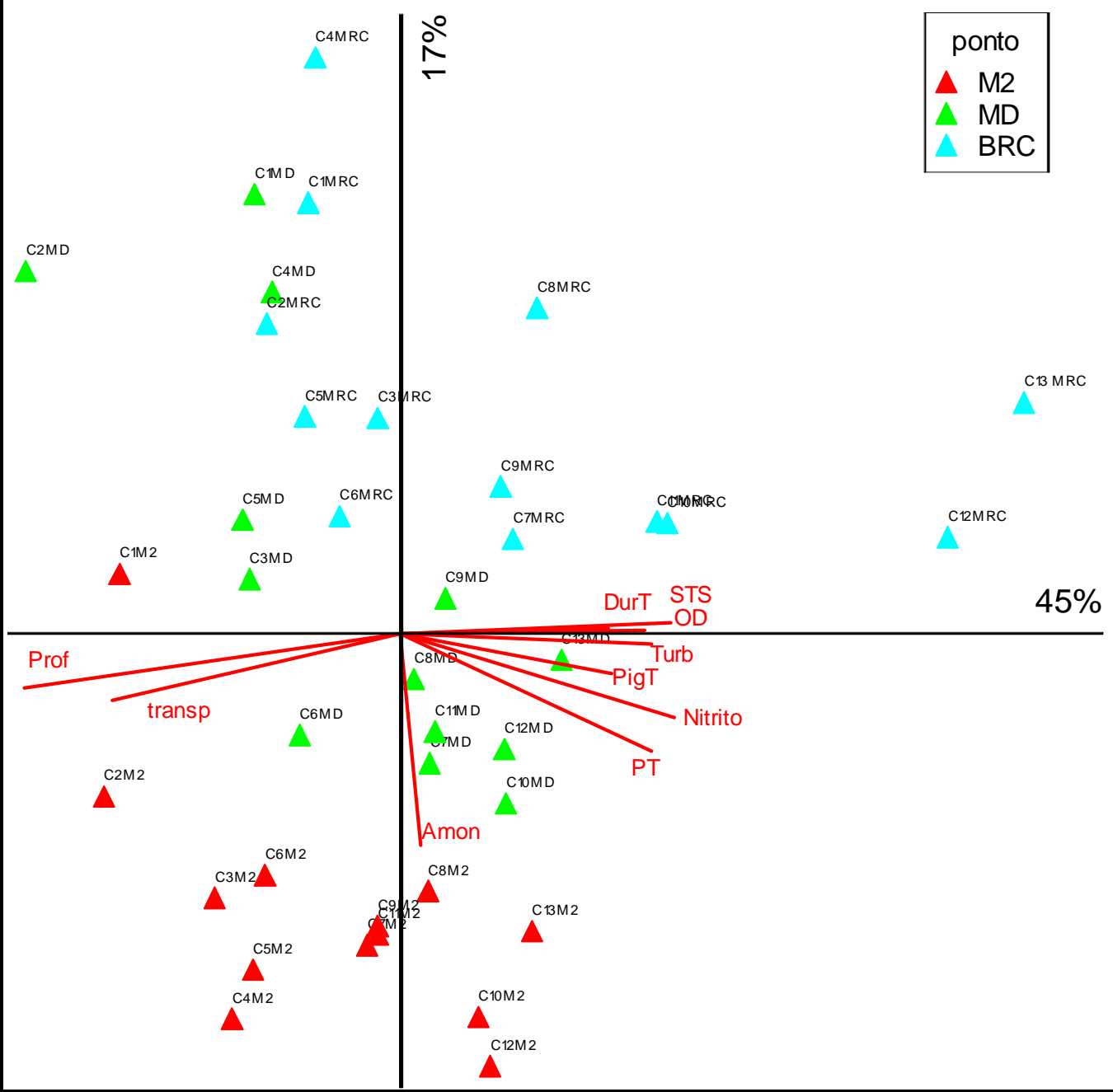

Figura 43 "Biplot" da ACP com a ordenação nos eixos 1 e 2 dos pontos de amostragem no eixo transversal do reservatório em 12 amostragens.

Tabela 6 : Correlação das variáveis no eixo transversal com os componentes principais 1 e 2 .

\begin{tabular}{lcc}
\hline & Autovetores & \\
\hline & $\mathbf{1}$ & $\mathbf{2}$ \\
\hline profundidade & $-0,3918$ & $-0,2410$ \\
\hline transparência & $-0,3424$ & $-0,2670$ \\
\hline oxigênio dissolvido & 0,3151 & 0,0650 \\
\hline turbidez & 0,3202 & $-0,1079$ \\
\hline dureza total & 0,2910 & 0,0708 \\
amônia & 0,0905 & $-0,4798$ \\
\hline nitrito & 0,3340 & $-0,3013$ \\
\hline STS & 0,3325 & 0,1064 \\
\hline P total & 0,3197 & $-0,3559$ \\
pigmentos totais & 0,2937 & $-0,2081$ \\
\hline
\end{tabular}


Considerou-se também, na análise realizada, a ordenação dos pontos em função do volume de ocupação do reservatório. Ao longo do estudo houve, em função da operação do reservatório uma grande redução do volume d'água armazenado. Uma análise de correlação simples de algumas variáveis com o volume armazenado mostrou maior relação das características da água com o volume ocupado do reservatório do que com a precipitação e mesmo com o tempo de residência (Tabela 7).

Tabela 7: Correlação das variáveis limnológicas com o tempo de residência, volume ocupado do reservatório e precipitação

\begin{tabular}{|c|c|c|c|c|c|c|c|c|c|c|c|c|c|c|c|c|}
\hline \multirow{7}{*}{$\begin{array}{l}\text { Tempo } \\
\text { de Residência }\end{array}$} & & transp & $\mathrm{pH}$ & $\mathrm{CE}$ & OD & Turb & POR & DurT & Alcal & Amon & Nitrito & Nitrato & STS & PT & PigT & $\mathrm{Si}$ \\
\hline & M1 & 0,3 & $-0,5$ & 0,3 & $-0,6$ & $-0,3$ & $-0,2$ & 0,4 & $-0,6$ & 0,4 & $-0,7$ & $-0,3$ & $-0,3$ & 0,0 & $-0,3$ & $-0,3$ \\
\hline & $\mathrm{M} 2$ & 0,3 & $-0,5$ & $-0,3$ & $-0,6$ & $-0,3$ & $-0,3$ & 0,8 & 0,2 & 0,5 & $-0,6$ & $-0,3$ & $-0,4$ & $-0,4$ & $-0,4$ & $-0,3$ \\
\hline & M3 & 0,5 & $-0,2$ & $-0,5$ & $-0,4$ & $-0,3$ & 0,4 & $-0,2$ & $-0,4$ & $-0,2$ & $-0,6$ & $-0,4$ & $-0,3$ & $-0,4$ & $-0,3$ & $-0,1$ \\
\hline & M4 & $-0,2$ & $-0,1$ & $-0,4$ & $-0,5$ & $-0,4$ & 0,1 & 0,0 & $-0,3$ & 0,4 & $-0,5$ & $-0,5$ & $-0,1$ & $-0,1$ & 0,3 & 0,1 \\
\hline & $\mathrm{MD}$ & 0,3 & $-0,4$ & $-0,2$ & $-0,7$ & $-0,2$ & $-0,6$ & 0,0 & $-0,4$ & $-0,2$ & $-0,6$ & $-0,4$ & $-0,5$ & $-0,6$ & $-0,3$ & $-0,3$ \\
\hline & BRC & 0,6 & 0,5 & 0,0 & $-0,3$ & $-0,2$ & $-0,2$ & 0,0 & $-0,2$ & $-0,4$ & $-0,2$ & $-0,6$ & $-0,3$ & $-0,2$ & $-0,4$ & $-0,2$ \\
\hline
\end{tabular}

\begin{tabular}{|c|c|c|c|c|c|c|c|c|c|c|c|c|c|c|c|c|}
\hline \multirow{7}{*}{$\begin{array}{l}\text { Volume } \\
\text { médio }\end{array}$} & & transp & $\mathrm{pH}$ & CE & OD & Turb & POR & DurT & Alcal & Amon & Nitrito & Nitrato & STS & PT & PigT & $\mathrm{Si}$ \\
\hline & M1 & 0,3 & $-0,5$ & $-0,2$ & $-0,6$ & $-0,8$ & 0,1 & 0,8 & 0,0 & 0,7 & $-0,7$ & $-0,2$ & $-0,3$ & $-0,3$ & $-0,3$ & 0,4 \\
\hline & M2 & 0,5 & $-0,6$ & $-0,6$ & $-0,7$ & $-0,8$ & 0,3 & 0,7 & $-0,2$ & 0,3 & $-0,7$ & $-0,4$ & $-0,4$ & $-0,5$ & $-0,7$ & 0,3 \\
\hline & M3 & 0,9 & $-0,2$ & $-0,6$ & $-0,6$ & $-0,8$ & 0,8 & 0,3 & $-0,9$ & $-0,7$ & $-0,8$ & $-0,6$ & $-0,7$ & $-0,8$ & $-0,6$ & 0,0 \\
\hline & M4 & $-0,5$ & $-0,5$ & $-0,9$ & $-0,3$ & $-0,6$ & 0,7 & 0,4 & $-0,7$ & 0,0 & $-0,8$ & $-0,4$ & 0,5 & $-0,2$ & 0,5 & 0,4 \\
\hline & $\mathrm{MD}$ & 0,5 & $-0,5$ & $-0,8$ & $-0,7$ & $-0,7$ & 0,2 & 0,7 & $-0,8$ & $-0,5$ & $-0,8$ & $-0,5$ & $-0,5$ & $-0,6$ & $-0,3$ & 0,4 \\
\hline & BRC & 0,9 & 0,9 & $-0,4$ & $-0,7$ & $-0,7$ & $-0,6$ & 0,7 & $-0,7$ & $-0,8$ & $-0,7$ & $-0,8$ & $-0,6$ & $-0,7$ & $-0,8$ & $-0,6$ \\
\hline
\end{tabular}

\begin{tabular}{|c|c|c|c|c|c|c|c|c|c|c|c|c|c|c|c|c|}
\hline \multirow{7}{*}{ Precipitação } & & transp & $\mathrm{pH}$ & CE & OD & Turb & POR & DurT & Alcal & Amon & Nitrito & Nitrato & STS & PT & PigT & $\mathrm{Si}$ \\
\hline & M1 & 0,0 & $-0,4$ & 0,2 & $-0,7$ & $-0,2$ & $-0,5$ & 0,2 & 0,0 & 0,5 & $-0,5$ & $-0,3$ & 0,2 & $-0,5$ & $-0,2$ & 0,0 \\
\hline & $\mathrm{M} 2$ & $-0,1$ & $-0,3$ & $-0,5$ & $-0,7$ & $-0,1$ & 0,0 & 0,3 & 0,3 & 0,5 & $-0,6$ & $-0,3$ & $-0,5$ & $-0,5$ & 0,0 & 0,0 \\
\hline & M3 & $-0,4$ & $-0,1$ & $-0,4$ & $-0,2$ & $-0,1$ & 0,2 & 0,0 & $-0,1$ & 0,4 & $-0,3$ & $-0,4$ & 0,3 & 0,2 & 0,6 & 0,4 \\
\hline & M4 & $-0,3$ & $-0,3$ & 0,0 & $-0,3$ & $-0,4$ & 0,2 & 0,1 & $-0,4$ & 0,5 & $-0,2$ & $-0,4$ & 0,2 & 0,1 & 0,7 & 0,5 \\
\hline & $\mathrm{MD}$ & $-0,1$ & $-0,1$ & $-0,2$ & $-0,4$ & 0,2 & $-0,3$ & $-0,3$ & $-0,4$ & $-0,6$ & $-0,5$ & $-0,3$ & $-0,3$ & $-0,7$ & $-0,1$ & 0,0 \\
\hline & BRC & 0,1 & $-0,2$ & 0,2 & $-0,2$ & $-0,2$ & 0,1 & 0,1 & $-0,5$ & $-0,1$ & $-0,4$ & $-0,1$ & 0,2 & $-0,5$ & 0,2 & 0,2 \\
\hline
\end{tabular}

A análise de componentes principais considerando todas as estações do reservatório no período de novembro de 2000 a abril de 2001, período no qual o reservatório possuía ocupação superior a 50\% de sua capacidade, resumiu 68\% de variação nos 2 primeiros eixos de ordenação (Figura 44 e Tabela 8). A ordenação dos pontos se deu principalmente em função da profundidade e transparência e a variáveis a elas relacionadas, como 
fósforo total, sílica, sólidos em suspensão e pigmentos totais. Esse período correspondeu ao período de estratificação na coluna d'água e a amônia esteve fortemente correlacionada aos pontos M1 e M2 em função das condições fortemente redutoras observadas na água de fundo nestas estações.

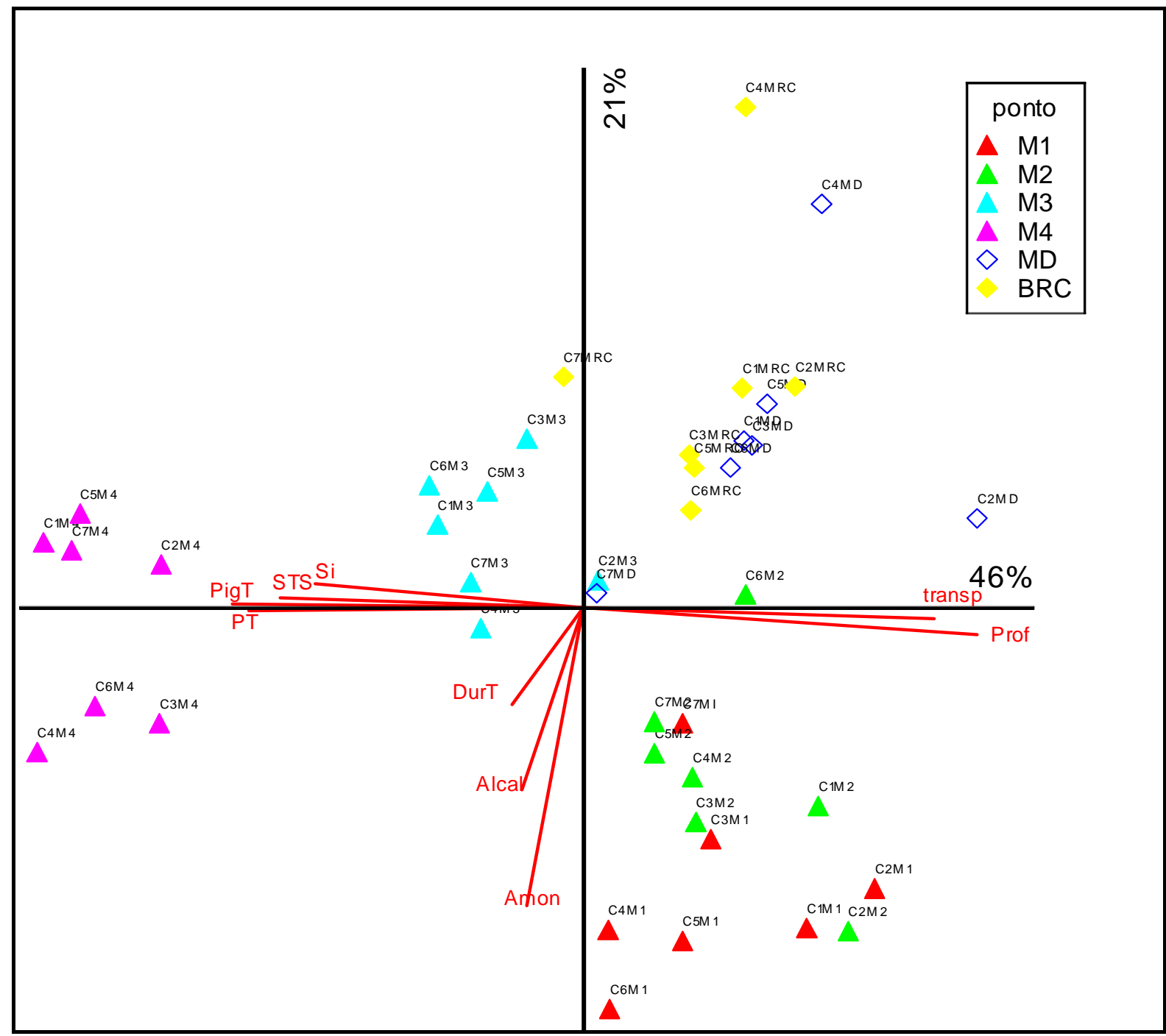

Figura 44 "Biplot" da ACP com a ordenação nos eixos 1 e 2 dos pontos de amostragem do reservatório nas amostragens em que o volume do reservatório era maior que $50 \%$ de sua capacidade 
Tabela 8: Correlação das variáveis no reservatório mais cheio com os componentes principais 1 e 2

\begin{tabular}{lcc}
\hline & Autovetores & \\
\hline profundidade & $\mathbf{1}$ & $\mathbf{2}$ \\
\hline transparência & 0,4243 & $-0,1685$ \\
\hline dureza total & 0,4003 & $-0,1068$ \\
\hline alcalinidade total & $-0,1794$ & $-0,3170$ \\
\hline amônia & $-0,1661$ & $-0,4355$ \\
STS & $-0,1610$ & $-0,5559$ \\
\hline P total & $-0,3717$ & 0,0990 \\
\hline pigmentos totais & $-0,3907$ & $-0,0617$ \\
\hline sílica reativa & $-0,4002$ & 0,0500 \\
\hline
\end{tabular}

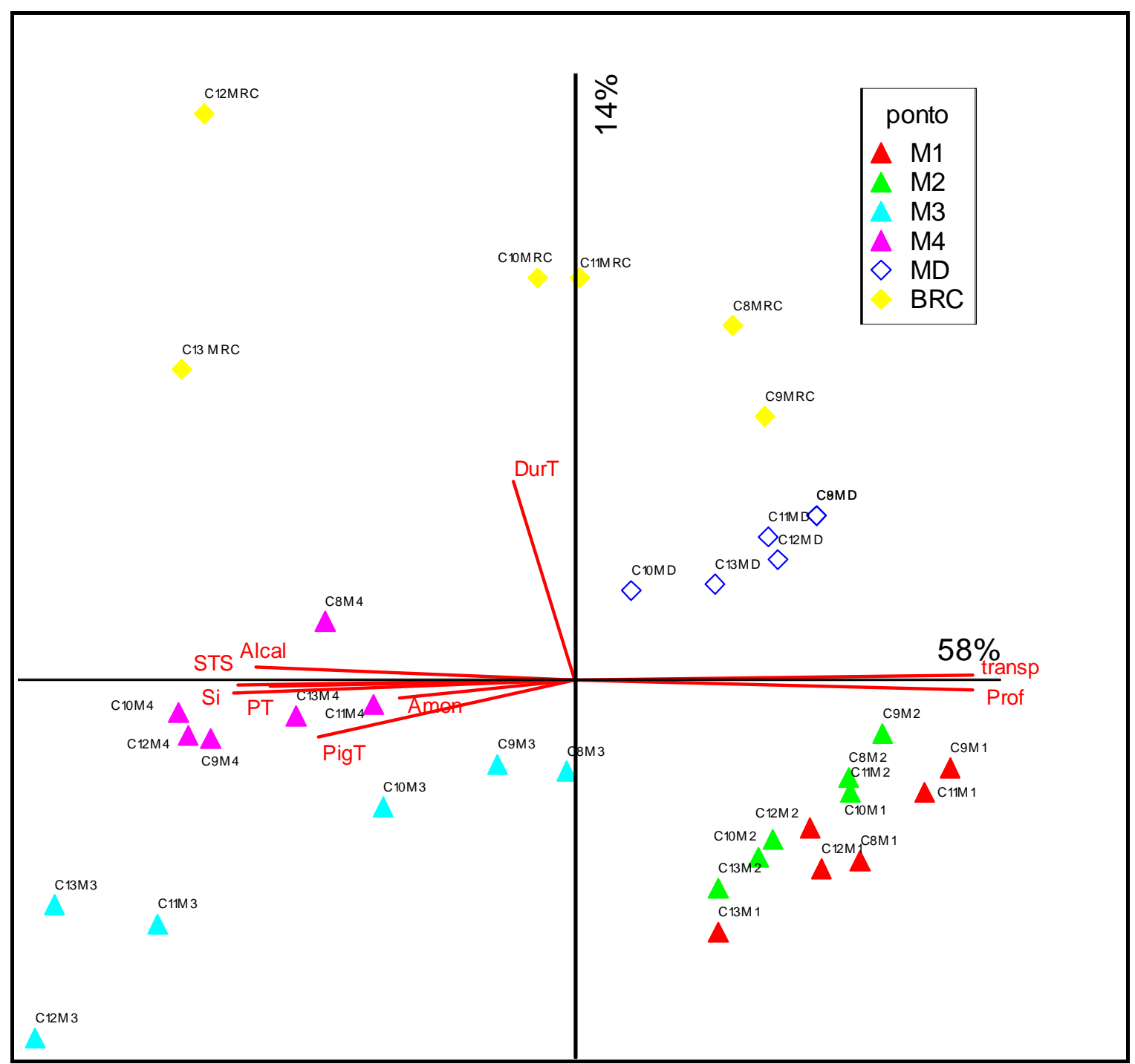

Figura 45: "Biplot" da ACP com a ordenação nos eixos 1 e 2 dos pontos de amostragem do reservatório nas amostragens em que o volume do reservatório era menor que $50 \%$ de sua capacidade 
Tabela 9 : Correlação das variáveis no reservatório mais vazio com os componentes principais 1 e 2

\begin{tabular}{lcc}
\hline & Autovetores & \\
\hline profundidade & $\mathbf{1}$ & $\mathbf{2}$ \\
\hline transparência & 0,3880 & $-0,1268$ \\
\hline dureza total & 0,3880 & 0,0886 \\
\hline alcalinidade total & $-0,1524$ & 0,5501 \\
\hline amônia & $-0,3477$ & 0,1384 \\
STS & $-0,2575$ & $-0,1677$ \\
\hline P total & $-0,3393$ & $-0,0977$ \\
\hline pigmentos totais & $-0,3596$ & $-0,1369$ \\
\hline sílica reativa & $-0,3114$ & $-0,2949$ \\
\hline
\end{tabular}

Na Figura 45 e Tabela 9 são apresentados os resultados da ACP para as estações do reservatório no período de menor volume armazenado, entre maio de 2000 e novembro de 2001, que sintetizou $71 \%$ da variação nos eixos 1 e 2. O agrupamento dos pontos de coleta observado mostra a importância das variáveis ligadas à profundidade, principalmente porque nesse período o reservatório apresentava condições de circulação total na coluna d'água.Um outro aspecto a ser ressaltado é forte relação do braço do Rio Claro com a dureza total, indicando, nesse período de menor volume de água a maior influência das águas afluentes do Rio Claro nesse ponto, uma vez que esse tributário apresenta composição iônica mais elevada que as águas do reservatório.

\section{4. Índice de Estado Trófico:}

Na Tabela 10 e Figura 46 são apresentados os Índices de Estado Trófico dos pontos do corpo central do reservatório.

Tabela 10: Índice de Estado Trófico de Carlson modificado por Toledo et al. (1983) calculado para o fósforo total

\begin{tabular}{lcccc}
\hline IET & M1 & M2 & M3 & M4 \\
\hline nov/00 & 23 & 16 & 31 & 43 \\
\hline dez/00 & 29 & 22 & 25 & 42 \\
\cline { 1 - 3 } jan/01 & 30 & 31 & 35 & 43 \\
\hline
\end{tabular}




\begin{tabular}{|c|c|c|c|c|}
\hline fev/01 & 26 & 30 & 35 & 44 \\
\hline mar/01 & 23 & 24 & 33 & 43 \\
\hline abr/01 & 22 & 27 & 38 & 42 \\
\hline mai/01 & 30 & 37 & 40 & 46 \\
\hline jun/01 & 34 & 32 & 41 & 44 \\
\hline jul/01 & 31 & 33 & 42 & 45 \\
\hline ago/01 & 33 & 35 & 41 & 43 \\
\hline set/01 & 25 & 28 & 45 & 37 \\
\hline out/01 & 29 & 37 & 54 & 49 \\
\hline nov/01 & 27 & 33 & 50 & 38 \\
\hline Média & 28 & 30 & 39 & 43 \\
\hline Desvio padrão & 4 & 6 & 8 & 3 \\
\hline $\mathrm{CV}(\%)$ & 14 & 21 & 20 & 7 \\
\hline $\begin{array}{l}\text { ultra-oligotrófico } \\
\text { oligotrófico }\end{array}$ & & & $\begin{array}{l}\text { Mesotrófico } \\
\text { Eutrófico }\end{array}$ & \\
\hline
\end{tabular}

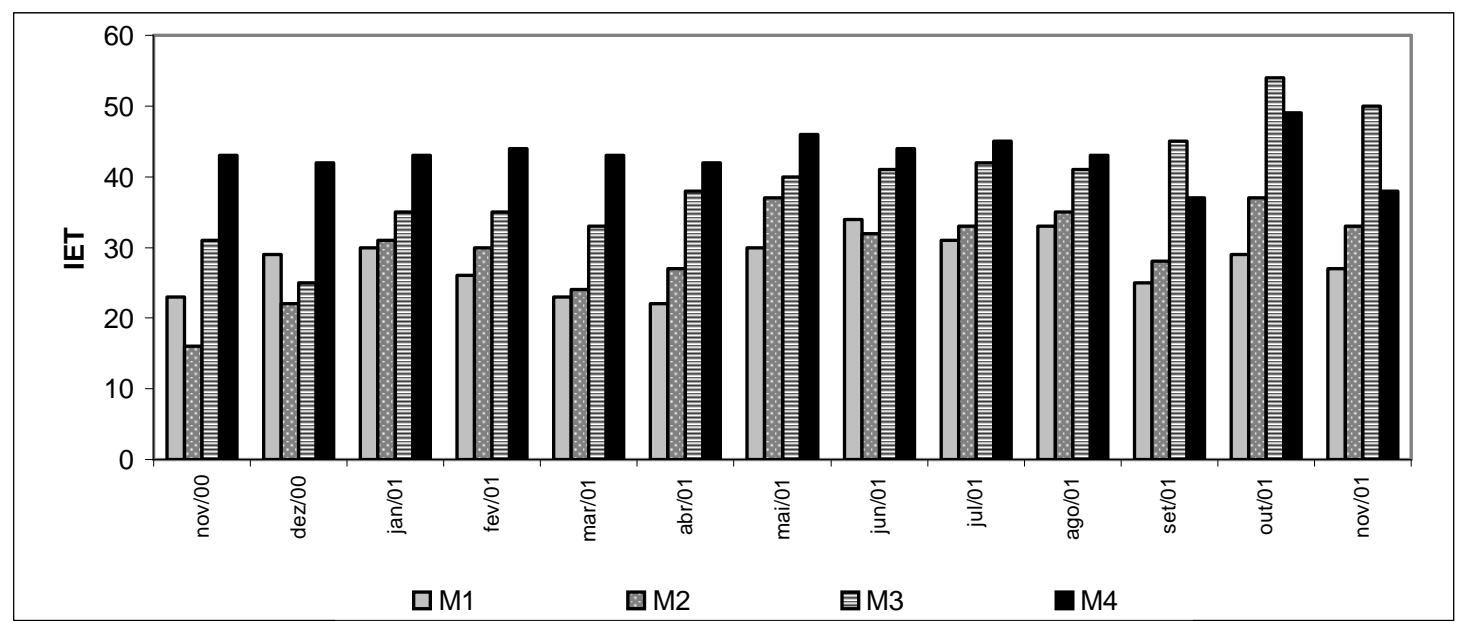

Figura 46: Variação do IET no corpo central do reservatório no período estudado

O Índice de Estado Trófico modificado evidenciou que a região da barragem (M1) assim como as estações M2 e M3 do corpo central são classificadas como oligotróficas. Já a estação próxima às cabeceiras (M4) mostrou evidências de início de processo de eutrofização.

Observou-se, de modo geral, um aumento do grau de trofia ao longo do eixo longitudinal do reservatório e um aumento significativo na estação M3 durante o período de estudo. Os valores mais elevados em todas as estações ocorreram no período de estiagem. 


\subsection{Tributários e saída do reservatório}

$\mathrm{Na}$ Tabela 11 são apresentadas as mesmas informações referentes aos tributários (Tietê montante e Rio Claro) e à água lançada no Tietê à jusante da barragem (Tietê jusante).

Tabela 11: Valores médios, desvio padrão e coeficiente de variação de variáveis físicas, químicas e biológicas nos tributários e a jusante do reservatório

\begin{tabular}{|c|c|c|c|c|c|c|c|c|c|c|c|c|c|c|c|c|c|c|c|c|c|c|c|c|c|c|}
\hline & & $\mathrm{pH}$ & Cond & Tur & $\mathrm{O}$ & termp & STD & POR & DrT & $\mathrm{Ca}$ & $\mathrm{Mg}$ & a & Aca. & DBO & $\infty$ & Anon & Ntnito & Ntrato & $\mathrm{FeT}$ & $\mathrm{s}$ & $\mathrm{Na}$ & $\mathrm{K}$ & STS & $\mathrm{Pg} \mathrm{T}$ & $\mathrm{PD}$ & PT \\
\hline & & & & & & & & & & & & & & & & & & & & & & & & & & \\
\hline \multicolumn{27}{|c|}{ TRBUTÁROS } \\
\hline & & & & & & & & & & & & & & & & & & & & & & & & & & \\
\hline \multirow[t]{3}{*}{ RoCaro } & Méda & 7,7 & 86,5 & 77,3 & 9,5 & 19,4 & 56,3 & 119,2 & 34,4 & 12,1 & 1,0 & 6,5 & 22,5 & 0,4 & 10,5 & 0,4 & 9,9 & 34,4 & 1,3 & 27 & 1,9 & 0,9 & 25,7 & 4,3 & 4,3 & 41,0 \\
\hline & desviopadrão & 1,3 & 54,7 & 102,5 & 0,7 & 2,5 & 35,4 & 53,5 & 24,9 & 10,4 & 0,9 & 28 & 19,9 & 0,4 & 8,6 & 0,3 & 17,8 & 41,6 & 1,1 & 0,8 & 0,4 & 0,3 & 42,9 & 6,8 & 27 & 40,5 \\
\hline & $\mathrm{CV}(\%)$ & 17 & ๒ & 133 & 8 & 13 & ๒ & 45 & 72 & 86 & 89 & 43 & 89 & 100 & 82 & 65 & 181 & 121 & 79 & 30 & 20 & 34 & 167 & 158 & 64 & 99 \\
\hline & & & & & & & & & & & & & & & & & & & & & & & & & & \\
\hline Tieê & Méda & 6,4 & 33,2 & 40,5 & 9,1 & 19,5 & 21,6 & 173,3 & 8,0 & 1,6 & 1,0 & 3,9 & 12,4 & 0,6 & 7,0 & 0,3 & 11,3 & 32,8 & 1,6 & 4,3 & 2,5 & 1,5 & 3,8 & 26 & 7,4 & 23,6 \\
\hline \multirow[t]{2}{*}{ montante } & desviopedrão & 0,2 & 21 & 28,5 & 0,5 & 26 & 1,4 & 32,1 & 1,6 & 0,3 & 0,4 & 0,8 & 2,3 & 0,4 & 26 & 0,1 & 5,0 & 120 & 0,6 & 0,6 & 0,4 & 0,4 & 2,5 & 1,2 & 3,5 & 14,6 \\
\hline & $\mathrm{CV}(\%)$ & 3 & 6 & 70 & 5 & 13 & 7 & 19 & 20 & 16 & 36 & 21 & 19 & 64 & 36 & 37 & 44 & 36 & 39 & 15 & 18 & 26 & 65 & 45 & 48 & 62 \\
\hline & & & & & & & & & & & & & & & & & & & & & & & & & & \\
\hline \multicolumn{27}{|l|}{ SAÍDA } \\
\hline & & & & & & & & & & & & & & & & & & & & & & & & & & \\
\hline Tietê & Méda & 6,3 & 39,2 & 17,9 & 4,8 & 21,2 & 25,4 & 56,8 & 12,4 & 22 & 1,7 & 4,7 & 13,9 & 0,3 & 3,7 & 0,9 & 5,9 & 9,7 & 1,2 & 0,3 & 21 & 1,3 & 2,9 & 5,7 & 3,8 & 11,4 \\
\hline \multirow[t]{2}{*}{ jusante } & desviopedrão & 0,1 & 7,6 & 25,9 & 3,4 & 21 & 4,8 & 136,9 & 12,7 & 0,7 & 28 & 0,8 & 3,4 & 0,5 & 1,0 & 0,7 & 24 & 2,2 & 1,1 & 0,3 & 0,2 & 0,2 & 1,9 & 6,6 & 2,3 & 3,3 \\
\hline & $\mathrm{CV}(\%)$ & 2 & 19 & 145 & 71 & 10 & 19 & 241 & 102 & 33 & 166 & 16 & 24 & 151 & 26 & 81 & 40 & 23 & 93 & 99 & 11 & 19 & 65 & 115 & 59 & 29 \\
\hline
\end{tabular}

Na Figura 47 é mostrada a variação da concentração na entrada e saída do reservatório dos principais nutrientes nitrogenados e fosfatados. Os resultados indicam concentrações inferiores na água de jusante, em relação à água dos principais tributários do reservatório, de nitrato, fosfato e fósforo total. A amônia, por sua vez, é superior na água de saída, principalmente no período de estratificação térmica, em função das condições redutoras do hipolímnio e da altura da tomada d'água para descarga retirar água desse compartimento. 

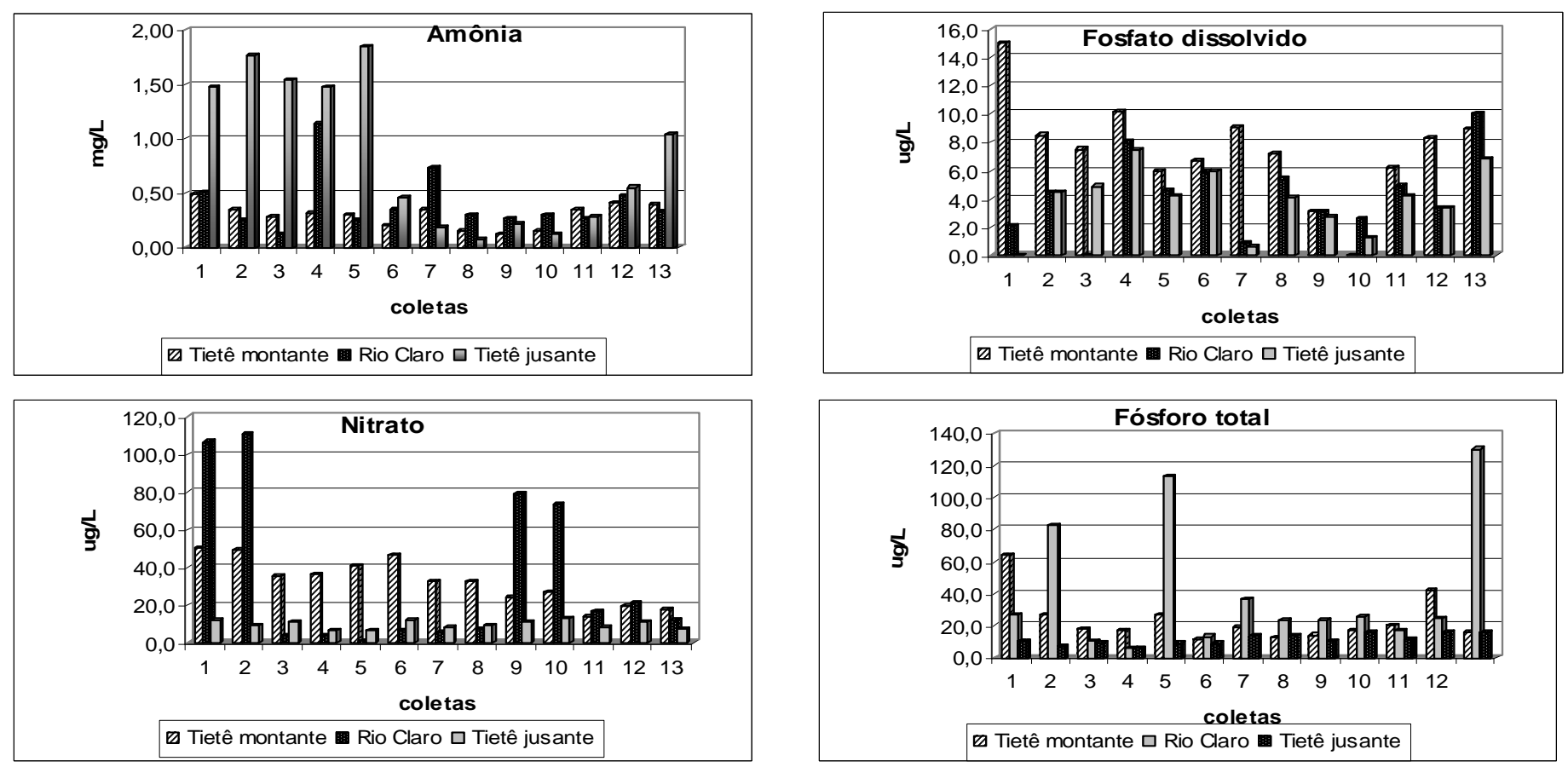

Figura 47: Variação sazonal de nutrientes nos tributários e na saída do reservatório. 


\section{Discussão}

O Reservatório de Ponte Nova apresentou valores reduzidos das concentrações dos principais nutrientes, típicas de um sistema oligotrófico e, apesar de ter apresentado, durante o período estudado, uma clara tendência à estratificação com água tendendo à anoxia, não apresentou valores de nutrientes, particularmente fósforo, muito elevados no fundo.

Ao longo do eixo longitudinal do reservatório observou-se um aumento da transparência e uma diminuição na concentração de nutrientes nitrogenados e fosfatados, ferro e sílica, indicando que o reservatório atua como um sistema de retenção de substâncias em relação às que afluem a ele. Tal constatação é corroborada na comparação dos valores presentes nos principais tributários, Tietê e Rio Claro, quando comparados com as características da água no Tietê imediatamente a jusante da barragem.

Portanto, os dados indicam que embora o reservatório não sofra influências antrópicas de grande magnitude, dada a ocupação predominantemente rural do seu entorno, ele atua como um sistema de retenção das influências recebidas, liberando menos nutrientes, particularmente fósforo, do que recebe. Sendacz et al(2005) constataram, na mesma bacia, que o reservatório de Jundiaí exporta nitrogênio e fósforo e o de Taiaçupeba exporta nitrogênio mas retém fósforo. Barbosa et al.(1998) registraram elevadas taxas de retenção de nitrogênio e fósforo na Lagoa Pampulha, fenômeno também verificado por Carmo et al.(2002) no lago das Garças, na cidade de São Paulo.

Padrão longitudinal similar ao observado em Ponte Nova, com diminuição da concentração de fósforo total em direção à barragem, foi observado por Thomaz et al (1997) no Reservatório de Segredo, no Rio 
Iguaçu. Nesse reservatório foi verificada, também, estratificação térmica por períodos prolongados, com efeitos na qualidade da água.

Os diagramas profundidade-tempo de temperatura, $\mathrm{pH}$, oxigênio dissolvido e potencial de oxi-redução revelam uma clara tendência à estratificação térmica e química do reservatório entre outubro e março. $\mathrm{Na}$ estações M1 e M2 o comportamento é similar, com uma clara separação das águas de fundo daquelas de superfície. As águas de fundo entre outubro e março apresentaram-se com pouco oxigênio ou completamente anóxicas, com pH ácido e potencial redox favorecendo a redução das espécies químicas. Tais condições são menos marcadas em M3, onde as profundidades são menores. Apesar de se situar na entrada da represa, normalmente associada a características lóticas, as condições em M4 são parecidas às condições lênticas do restante do reservatório, em função do represamento das águas nesse trecho pelo aterro aí presente.

Em relação ao eixo lateral do reservatório, considerando o seu trecho mais largo, representado pelas estações MD, M2 e braço do Rio Claro (ME), os diagramas mostram que o comportamento da coluna d'água na margem direita é semelhante ao do corpo central, em função da ausência de tributários significativos nessa margem e profundidade elevada. Já na margem esquerda (braço do Rio Claro) há um comportamento diferente, com estabilidade menor da estratificação em função da menor profundidade e pela influência da entrada do Rio Claro.

A Análise de Componentes Principais evidenciou ao longo do eixo maior do reservatório uma separação espacial entre as estações M1, M2, M3 e M4. As estações M1 e M2, situadas próximas à barragem, apresentando valores mais elevados de profundidade e transparência da água. Já as estações M3 e M4, mais próximas às cabeceiras e assoreadas pela presença de um aterro, apresentaram concentrações de pigmentos totais, 
fósforo total, STS, nitrito e nitrato mais elevadas em relação às estações M1 e M2. O eixo 1 representaria, desta maneira, o gradiente de eutrofização.

Esta separação espacial entre estações foi menos evidente na ACP aplicada ao longo do eixo transversal, onde ocorreu uma homogeneidade em relação a algumas variáveis, tais como transparência, pigmentos e fósforo total. Apesar disso a análise evidenciou valores mais elevados de algumas variáveis (nitrato, nitrito, STS e turbidez) nos braços MD e BRC. Constatou-se, no entanto, uma separação temporal entre as estações quanto às características físicas e químicas, separação essa bastante relacionada ao volume de água armazenado.

As baixas precipitações verificadas em 2001 e a operação do sistema causaram, na represa estudada, uma queda acentuada dos níveis de água, acarretando exposição das margens e, provavelmente, alterações na dinâmica de circulação da massa d'água.

Flutuações de nível d'água são comuns em reservatórios, associadas a variações climáticas e à utilização antropogênica das águas. Tais flutuações alteram a qualidade da água e apresentam implicações para o manejo de reservatórios (Geraldes e Boavida, 2005).

A variação da concentração de fósforo, em função de sua importância para o processo de eutrofização, associada a flutuações do nível d'água tem sido particularmente estudada em reservatórios (Fabre, 1988; Watts, 2000; Geraldes e Boavida, 2005; Tüzün \& Ince, 2006) e é uma questão fundamental para as ações de manejo.

Verificou-se, ao longo de duas décadas, que o processo de eutrofização foi muito mais intenso em outras represas do Alto Tietê, como Billings e Guarapiranga (Sendacz \& Kubo, 1999) do que em Ponte Nova. Como exemplo, em 1979, a média de condutividade elétrica na represas Ponte Nova e Guarapiranga nos períodos estiagem-frio e chuvoso-quente foi, 
respectivamente, 25 e 47 uS.cm ${ }^{-1}$, e 43 e 41 uS.cm ${ }^{-1}$ (Maier \& Takino,1985a); neste estudo, constatou-se em Ponte Nova 33 e 32 uS.cm 1, e em Guarapiranga, 147 e 127 uS.cm ${ }^{-1}$ (Sendacz \& Caleffi, em prep.). Foi também constatado um leve aumento nas concentrações de clorofila $a$ em Ponte Nova no período estiagem-frio, de 3,6 a 5,9 ug. $1^{-1}$, e uma diminuição no período chuvoso-quente, de 12,9 a 5,3 ug. $1^{-1}$ (Maier \& Takino, 1985b). Para efeitos comparativos, na represa Guarapiranga as concentrações foram de 4,4 e 9,0 ug. $1^{-1}$, a 31,2 e 25,9 ug. $1^{-1}$ (Maier \& Takino, op. cit) , considerando os períodos estiagem-frio e chuvosoquente.

De acordo com Vollenweider (1968, in Esteves, 1988), Ponte Nova se enquadraria como um corpo d'água oligotrófico em relação às concentrações de amônia, que estiveram abaixo de $0,3 \mathrm{mg} \mathrm{l}^{-1}$, de nitrato, abaixo de $1,0 \mathrm{mg} \mathrm{l}^{-1}$, e de nitrito, abaixo de $0,5 \mathrm{mg} \mathrm{l}^{-1}$.

Em relação ao Índice de Estado Trófico (IET), considerou-se na represa estudada o critério adotado por Kratzer \& Brezonick: valores de IET abaixo de 40 caracterizariam corpos d'água oligotróficos, valores entre 41 e 50, mesotróficos, entre 51 e 60, eutróficos, acima de 61, hipereutróficos.

O Índice de Estado Trófico Modificado evidenciou que a região da barragem e o corpo central caracterizam o reservatório como oligotrófico excetuando-se a região próxima à cabeceira, que mostra evidências de início de processo de eutrofização. Comparando-se os índices obtidos neste estudo com outros corpos d'água do Alto Tietê, verifica-se que a represa Guarapiranga apresentou índices semelhantes aos determinados no Complexo Billings, braços Rio Grande e Taquacetuba, respectivamente 67 e 62 (CETESB, 1999; Coelho-Botelho et al., em prep). Desta maneira, pode-se dizer que a Represa de Ponte Nova ainda 
mantém suas características de oligotrofia quando comparada com os resultados obtidos nos estudos realizados nas décadas de 70-80.

As ações de manejo na represa de Ponte Nova que podem ser apontadas incluem ações a nível da bacia e do reservatório.

$\mathrm{Na}$ bacia, embora não existam ações impactantes significativas, há áreas críticas, particularmente em Salesópolis, na área do aterro que represou parcialmente a entrada do reservatório. Nessa região são necessárias ações de recomposição vegetal e de controle de uso do solo, uma vez que a atividade erosiva já tem certa expressão.

No reservatório as ações possíveis dizem respeito ao manejo do tempo de residência, de tal forma que a renovação da massa d'água dificulte a estratificação e a formação de condições de anoxia no fundo, verificada durante o trabalho. Essa ação, no entanto, não deve provocar um deplecionamento tão grande quanto o que foi praticado no período de estudo, uma vez que as áreas expostas, uma vez re-inundadas, contribuem com o acréscimo de nutrientes e matéria orgânica para a água do reservatório. 
- O Índice de Estado Trófico Modificado evidenciou que a região da barragem e o corpo central caracterizam o reservatório como oligotrófico excetuando-se a região próxima à cabeceira, que mostra evidências de início de processo de eutrofização.

- Os dados de jusante indicam concentrações de nutrientes e de material em suspensão de modo geral inferiores àquelas registradas nos principais tributários, indicando uma retenção eficiente da carga afluente ao reservatório.

- O reservatório apresentou, na maior parte do ano amostrado, uma estratificação térmica e química bem definidas, com grande estabilidade, apesar da turbulência das águas do reservatório, característica essa de ambientes eutrofizados, com alta demanda de consumo de oxigênio nas águas mais profundas. No período de estiagem, quando houve circulação total na coluna d'água, houve também uma redução significativa do volume armazenado, em função do aumento significativo das vazões efluentes do reservatório para suprimento de demandas de outros reservatórios.

- Além da compartimentação vertical verificada no período de estratificação, os dados indicaram características distintas ao longo do eixo longitudinal do reservatório e nos compartimentos de margem. Essas diferenças puderam ser explicadas por algumas variáveis limnológicas e estiveram de modo geral associadas à profundidade e à entrada dos tributários.

- As ações de manejo na represa de Ponte Nova para manutenção da qualidade da água apontadas incluem ações a nível da bacia, particularmente para controle de erosão e a nível do reservatório, 
relacionadas à manipulação do tempo de residência. e da magnitude do deplecionamento. 
AMBROSETTI, W.; BARBANTI, L.; SALA, N.. Residence time and physical processes in lakes. J.Limnol. 62 (Suppl. 1): 1-15. 2003

APHA (AMERICAN PUBLIC HEALTH ASSOCIATION) Standard Methods for examination of water and wasterwater. Washington, DC,. (20 a ed.). 1998.

ARMENGOL, J.; GARCIA, J.C.; COMERMA, M.; ROMERO, M.; DOLZ, J.; ROURA, M.;HAN, H.B; VIDAL, A.; SIMEK, K.. Longitudnal processes in canyon type reservoirs: The case of Sal (N.E. Spain). In: TUNDISI, J.G. \& STRASKRABA, M. (eds). Theoretical reservoir ecology and its applications. Brazilian Academy of Sciences, International Institute of Ecology and Backhuys Publ., São Carlos, pp.313-345. 1999.

BARBOSA, F.A.; GARCIA, F.C.; MARQUES, M.G.S.M.; NASCIMENTO, F.A. Nitrogen and phosphorus balance in a eutrophic reservoir in Minas Gerais - a first approach. Rev. Bras. Biol. 58: 233239, 1998.

BASILE-MARTINS, M.A.; CIPÓLLI, M.N. \& CESTAROLLI, M.A. Limnologia de reservatórios do sudeste do Estado de São Paulo, Brasil. VI. Produção primária. B. Inst. Pesca, 12(1):123-143. 1985.

CARMO, C.E.; HENRY, R.; BICUDO, D.C.;BICUDO, C.E.M. A degradação nos reservatórios do PEFI. In: BICUDO, D.C.; FORTI, M.C.; BICUDO, C.E.M. (Eds). Parque Estadual das Fontes do Ipiranga (PEFI): uma unidade de conservação que resiste à urbanização de São Paulo, 2002, p. 273-296. 
CARMOUZE, J.P. O metabolismo dos ecossistemas aquáticos: fundamentos teóricos, métodos de estudo e análises químicas. Editora Edgard Blücher/FAPESP, São Paulo. 1994.253p.

CETESB Qualidade das águas interiores do Estado de São Paulo.CETESB, São Paulo. 1995

CIPOLLI, M.N.; AMORIM, D.S. Tipologia de reservatórios do Estado de São Paulo. Bentos. Relatório apresentado à FAPESP. 1980.

ESTEVES, F.A. Fundamentos da Limnologia. Interciência, Rio de Janeiro. 1988. 575p.

ESTEVES, K.E. \& SENDACZ, S. Relações entre a biomassa do zooplâncton e o estado trófico de reservatórios do Estado de São Paulo. Acta Limnologica Brasiliensia 2: 587-604. 1988.

FABRE, A. Experimental studies on some factors influencing phosphorus solubilization in connexion with the drawdown of a reservoir. Hydrobiologia 159: 153-158. 1988.

GARZON, C.E. Water quality in hydrometric projects: considerations for planing in tropical forest regions. Teh Worl Bank Tech. Pap., 20:1-33. 1984.

GERALDES, A.M. \& BOAVIDA, M.J. Seasonal water level fluctuations for reservoir limnology and management. Lakes \& Reservoirs: Research and Management 10: 59-69. 2005.

HÅKANSON, L. \& PETERS, R.H. Predictive limnology methods for predictive modeling. SBP Academic Publishing, Amsterdam. 1995.464p.

HÅKANSON, L. Internal loading: a new solution to na old problem in aquatic sciences. Lakes and Reservoirs: Research and Management 9: 3-23. 2004. 
HUEFTLE, S.J. \& STEVENS, L.E. Experimental flood effects on the limnology of Lake Powell Reservoir, Southwestern USA. Ecological Applications 11(3): 644-656. 2001.

HUTCHINSON, G.E. . A treatise on Limnology. Vol 1, Geogrqphy, physics and chemistry. John Wiley \& Sons, New York. 1957. 1015p.

JØRGENSEN, S.E. Application of ecological engineering principles in lake management. Lakes \& Reservoirs: Research and Management 11: 103-109. 2006

JØRGENSEN, S.E. The application of models to find the relevance of residence time in lake and reservoir management. J.Limnol. 62 (Suppl. 1): 16-20. 2003.

JUREIDINI, P.; CHINEZ, S.J. \& AGUDO, E.G Medições da produção primária em três reservatórios do Estado de São Paulo. Ciência e Cultura, 35(9): 1341-1346. 1983

KENNEDY, R.H. Reservoir design and operation: limnological implications and management opportunities. In: TUNDISI, J.G. \& STRASKRABA, M. (eds). Theoretical reservoir ecology and its applications. Brazilian Academy of Sciences, International Institute of Ecology and Backhuys Publ., São Carlos, pp.1-28. 1999

LEGENDRE , L. \& LEGENDRE, P. Numerical ecology. Elsevier, New York. 1983. 419p.

LEWIS, Jr, W.M.. Basis for the management of tropical lakes. Lakes and Reservoirs: Research and Management 5: 35-48. 2000

LIND, O. Patterns of phytoplankton populations and their relationship to trophic state in an elongated reservoir. Verh. Interenat. Verein. Limnol. 22: 1465-1469. 1984. 
MACEDO, A.B.Banco de dados espaciais da Bacia Hidrográfica do Alto Tietê.Instituto de Geociências, Universidade de São Paulo, São Paulo, 1998.

MAIER, M.H. \& TAKINO, M. Limnologia de reservatórios do sudeste do Estado de São Paulo, Brasil. III. Qualidade da água. B. Inst. Pesca, 12(1):45-73. 1985a

MAIER, M.H. \& TAKINO, M. Limnologia de reservatórios do sudeste do Estado de São Paulo, Brasil. IV. Nutrientes e clorofila a. B. Inst. Pesca, 12(1):75-102. 1985b

MAIER, M.H. Limnologia de reservatórios do sudeste do Estado de São Paulo, Brasil. II. Circulação e estratificação da água. B. Inst. Pesca, 12(1):11-43. 1985

MANTOVANI, W. et al. A vegetação da Serra do Mar em Salesópolis, SP. In: Simpósio de Ecossistemas da Costa Sul e Sudeste Brasileira. Estrutura, função e manejo. 2. Publicação ACIESP 71, São Paulo, pp.348-385. 1990

NIMER, E. Climatología do Brasil. $2^{\mathrm{a}}$ ed. Secretaria de Planejamento da Presidência da República/Fundação IBGE, Rio de Janeiro. 1989

PUCCINI, D.S.P. Ecological models and environmental studies. Water Resources Bull., 7: 1114-1152. 1971.

REYNOLDS, C.S. The ecology of freshwater phytoplankton. Cambridge University Press, Cambridge. 1984. 384p.

SALAS, H.J. \& MARTINO, P. Metodologias simplificadas para la evaluación de la eutrofización en lagos calidos tropicales. Washington: CEPIS/HPE/OPS, 1990. 51p.

SALMASO, N.; MOSELLO, R.; GARIBALDI, L.; DECET, F.; BRIZZIO, M.C.; CORDELLA, P.. Vertical mixing as a determinant of 
trophic status in deep lakes: a case study from two lakes south of the Alps (Lake Garda and Lake Iseo). J.Limnol. 62 (Suppl. 1): 33-41. 2003.

SCHÄFER, A. Fundamentos de ecologia e biogeografia das águas continentais. Editora da Universidade Federal do Rio Grande do Sul, Porto Alegre. 1985. 533p.

SENDACZ, S.; KUBO, E. \& CESTAROLLI, M.A. Limnologia de reservatórios do sudeste do Estado de São Paulo, Brasil. VIII. Zooplâncton. B. Inst. Pesca, 12(1):187-207. 1985.

SENDACZ, S; MONTEIRO JUNIOR, A.J.;MERCANTE, C.T.; MENEZES, L.C.B.; MORAES, J.F. Sistemas em cascata: concentrações e cargas de nutrientes no Sistema Prdutor Alto Tietê, São Paulo. In: NOGUEIRA, M.G.; HENRY, R.; JORCIN, A.(org). Ecologia de Reservatórios: Impactos potenciais, Ações de manejo e Sistemas em Cascata. Ed.RIMA, São Carlos, pp. 417-734. 2005.

STRASKRABA, M. Lake and reservoir management. Verh. Internat. Verein.Limnol. 26: 193-209. 1996

STRASKRABA, M. Retention time as a key variable of reservoir limnology. In: TUNDISI, J.G. \& STRASKRABA, M. (eds). Theoretical reservoir ecology and its applications. Brazilian Academy of Sciences, International Institute of Ecology and Backhuys Publ., São Carlos, pp.385-410. 1999.

STRASKRABA, M.; TUNDISI, J.G.; DUNCAN, A.(eds). Comparative reservoir limnology and water quality management. Kluwer Academic Publishers, Dordrecht. 1993. 291p.

TER BRAAK, C.J. F. Ordination - Chapter 5 In: Jongman, R.H.G., Ter Braak, C.J.F. e Van Tongeren, O.F.R.. (Eds.). Data analysis in community and landscape ecology. Pudoc, Wageningen, 1987 
THOMAZ, S.M.; BINI, L.M.; ALBERTI, S.M. Limnologia do Reervatório de Segredo: padrões de variação espacial e temporal. In: AGOSTINHO, A.A.\& GOMES L.C.. Reservatório de Segredo - bases ecológicas para o manejo. EDUEM, Maringá, 1997, p. 19-37.

THORNTON, K.W.; KIMMEL, B.L.; PAYNE, F.E. (eds) Reservoir limnology: ecological perspectives. J.Wiley, New York. 1990. 246p.

TOLEDO JR., A. P. et al Estudo da eutrofização do Reservatório Ponte Nova. XI Congresso Brasileiro de Engenharia Sanitária, Fortaleza, CE, 1981

TOWNSEND, S.A. Metalimnetic and hypolimnetic deoxygenation in an Australian tropical reservoir of low trophic status. In: F. SCHIEMER \& K.T.BOLAND (eds). Perspectives in Tropical Limnology, pp.151-160. 1996

TUNDISI, J.G. \& STRASKRABA, M. (eds). Theoretical reservoir ecology and its applications. Brazilian Academy of Sciences, International Institute of Ecology and Backhuys Publ., São Carlos. 1999. $592 p$.

TUNDISI, J.G. Distribuição espacial, sequência temporal e ciclo sazonal do fitoplâncton em represas: fatores limitantes e controladores. Rev. Brasil. Biol. 50(4): 937-955. 1990.

TÜZÜN, I. \& INCE, O. Relationship between water flow volume and inlake total phosphorus concentrations via dissolved oxygen concentrations and temperature in a warm temperate reservoir: implications by path analysis. Lakes \& Reservoirs: Research and Management 11: 83-96. 2006

WATTS, C.J. Seasonal phosphorus release from exposed, re-inundated littoral sediments of two Australian reservoirs. Hydrobiologia 431: 2739. 2000 
XAVIER, M.B., MONTEIRO-JUNIOR, A.J. \& FUJIARA, P. Limnologia de reservatórios do sudeste do Estado de São Paulo, Brasil. VII. Fitoplâncton. Bol. I. Pesca, São Paulo, 12(1):145-186.. 1985. 